Isabele Fattori Moretti

Toll like receptor 4 among the plasmatic membrane Toll like receptors plays a role in astrocytoma malignancy

Receptor do tipo Toll 4 dentre os TLRs de membrana plasmática possui um papel na malignidade de astrocitomas

Dissertação apresentada à Faculdade de Medicina da Universidade de São Paulo para obtenção do título de Mestre em Ciências

Programa de Neurologia

Orientadora: Prof. Dra. Suely Kazue Nagahashi Marie

\title{
São Paulo
}




\section{Pados Internacionais de Catalogação na Publicação (CIP)}

Preparada pela Biblioteca da

Faculdade de Medicina da Universidade de São Paulo

Creprodução autorizada pelo autor

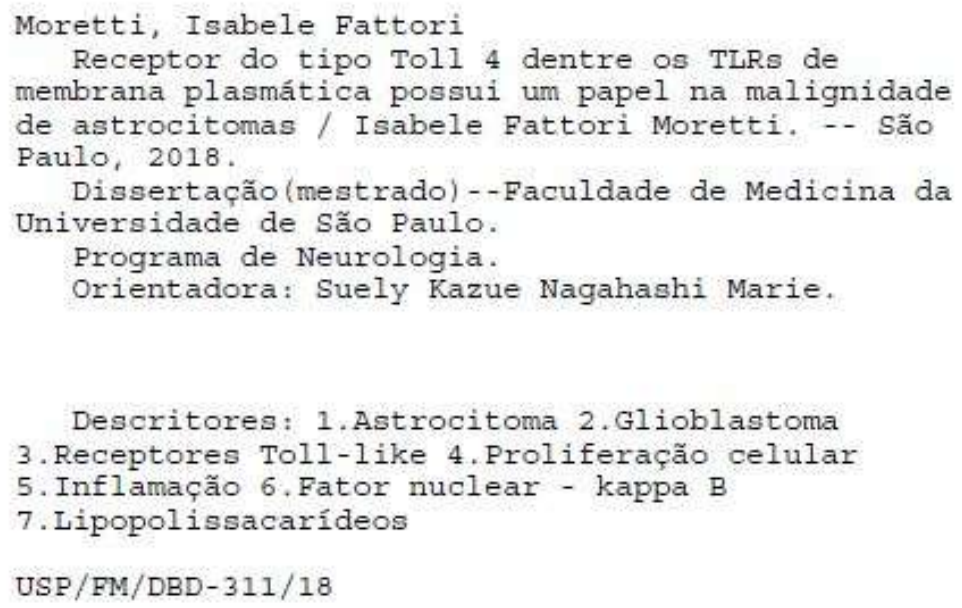

Responsável: Eidi Raquel Franco Abdalla - CRB-8/4901 


\section{Agradecimentos}

“Há em cada um e nós, uma floresta virgem, emaranhada, inexplorada; um campo nevado onde não se veem nem pegadas de pássaros." Virginia Wolf No processo de construção dessa dissertação de mestrado me deparei com grandes dificuldades que com um grande esforço foram absorvidas e me permitiram que eu amadurecesse profissionalmente e pessoalmente. E para que isso ocorresse obtive a ajuda e o apoio da Prof $^{\mathrm{a}}$ Dr$^{\mathrm{a}}$ Suely Marie, que foi além de orientadora e com todo seu empenho e dedicação permitiu que eu pudesse realizar esse trabalho. E com grande ajuda da Dra. Sueli Oba-Shinjo que proporciona o funcionamento a todo vapor do laboratório LIM15 nos deixando realizar grandes feitos. Às duas meus mais sinceros agradecimentos.

E às pessoas presentes em nossa rotina, que com muito humor fizeram meus dias mais animados e proveitosos. Agradeço às meninas do LIM-15 Stella Cavalcante, por toda ajuda, compreensão e companhia. À Daiane Franco, por toda ajuda no início do mestrado, participando e me ajudando na elaboração dos experimentos. À Paula Sola que com toda dedicação me ensinou a trabalhar com biologia molecular. À Roseli Silva e Laís Cavalca que me ensinaram e ajudaram no trabalho com cultura celular. À Fernanda Serachi, por toda descontração, e companhia nos almoços e lanches do McDonalds, à Talita Laurentino por toda ajuda, à Natália Cagnin por me tirar da rotina e me arrastar para alguns dias de sol, à Adaliana Moussessian, Marina Trombetta, Yollanda Moreira, Keyde Melo, Nathalia Villa, Tawany Carvalho, Amanda Narcizo, Camila Dantas, Mariana Molina. Muito obrigada à todas, sem vocês meus dias com certeza não seriam tão agradáveis.

E aos funcionários, Eliene, Rosa, Nice, Luís, Márcia, Darcy e Camila. 
E a todos que colaboraram com o grupo LIM-15, que sempre acabam nos ajudando e muito na parte científica. Agradeço ao Prof. Bart Eggen, Profa. Ody Sibon, Nieske Brouwer, Dr. Antonio Lerario, à Dipika Mohan, ao confocal do CEFAP comandado pelo Mário Costa.

Ao grupo de neurocirurgia do Hospital das Clínicas que se engajaram há mais de dez anos nesse projeto e possibilitaram a construção do biorrepositório que até hoje permite que façamos grandes projetos.

$E$ àquelas pessoas que ficam no plano de fundo que me apoiam emocionalmente. Sinto que sou uma pessoa extremamente privilegiada por possuir a família que tenho, e tudo que eu faço sei que tenho o apoio e a compreensão deles que não me deixaram cair. Aos meus pais e minha irmã agradeço por tudo, porque sem eles não seria nada.

Agradeço também aos meus amigos, pessoas extraordinárias que me inspiram cada um à sua maneira e não me deixam parar. À Alessandra e ao Caio, acho que quase 20 anos na minha vida não consigo nem pensar em quem eu seria sem eles. Ao meu grupo querido que me xingam por eu não estar presente, mas eu sei que o que mais querem é minha felicidade, e eu agradeço por quererem me tirar de casa, me tirar da zona de conforto, Salsicha, Aline, Moreno, Fininho e Vandinha muito obrigada por tudo. E também à Alice, Gabriella, Coração, Yasmim, Chico, Pryscilla.

E agradeço à Fundação de Amparo à Pesquisa do Estado de São Paulo FAPESP (no do processo 2016/14695-9) que permitiu que eu pudesse continuar a investir em minha carreira acadêmica. 
"I remembered that the real world was wide, and that a varied field of hopes and fears, of sensations and excitements, awaited those who had the courage to go forth into it's expanse, to seek real knowledge of life amidst it's perils." Charlotte Brontë 


\section{Summary}

Abbreviation list

Table list

Figures list

Abstract

Resumo

1. Introduction 1

2. Aims

3. Materials and Methods $\quad 8$

3.1. Tumor samples and ethical statement 8

3.2. Sample preparation and RNA extraction 8

3.3. Quantitative Real-Time PCR (qRT-PCR) 9

3.4. Immunofluorescence 10

3.5. Immunohistochemistry 10

3.5.1. Immunohistochemistry in tissue microarray (TMA)

3.6. TLR4 activation in U87MG cell 12

3.7. Cellular Proliferation assay 12

3.8. NF-kB translocation to nucleus 12

3. 9. TLR4 chemical inhibition 13

3.10. Statistical analysis 13

$\begin{array}{ll}\text { 4. Results } & 15\end{array}$

4.1. TLR1, TLR2, TLR4, TLR5, and TLR6 mRNAs were up-

4.2. Associated TLRs expressions were observed in GBM 15

4.3. Higher TLR4 and TLR6 median expression levels were
observed in mesenchymal GBM compared to other molecular subtypes

4.4. TLR1, TLR2, TLR4, TLR5, and TLR6 were present in tumor cell lines

4.5. TLR1, TLR2, TLR4, TLR5, and TLR6 protein presence in GBM tissue $\quad 20$

4.6. In silico exploration of TLR signaling pathway 22

4.7. TLR4 presence in human astrocytoma $\quad 25$

4.7.1. TLR4 expression is the highest among the plasma membrane TLRs in human astrocytomas and U87MG cell line 25

4.8. The impact of inhibiting TLR4 in U87MG cells 25

4.8.1 TLR4 pathway pharmacological inhibition 26

4.8.2 TLR4 in tumor and microglia cells crosstalk 27

5. Discussion $\quad 30$

6. Conclusions 36

$\begin{array}{ll}\text { 7. References } & 37\end{array}$ 
8. Attachment 44

8.1. Attachment 1: Supporting information figure 44

8.2. Attachment 2: Cep Feedback 46

8.3. Attachment 3: qRT-PCR data 49

8.4. Attachment 4: Paper formal acceptance 57

8.5. Attachament 5: Abstract of Plos one Paper - Plasmatic membrane toll-like receptor expressions in human astrocytomas 57 


\section{Abbreviation list}

$\begin{array}{ll}\mu \mathrm{g} & \text { Micrograma } \\ \mu \mathrm{M} & \text { Micromolar } \\ \text { AGII } & \text { astrocytoma grade II } \\ \text { AGIII } & \text { astrocytoma grade III } \\ \text { AGIV } & \text { astrocytoma grade IV } \\ \text { AIF1 } & \text { allograft Inflammatory factor 1 } \\ \text { AKT } & \text { serine/threonine kinase 1 } \\ \text { AKT1 } & \text { AKT serine/threonine kinase 1 } \\ \text { ARHGAP6 } & \text { rho GTPase activating protein 6 } \\ \text { ATCC } & \text { American Type Culture Collection } \\ \text { BCL2L1 } & \text { apoptosis regulator Bcl-X } \\ \text { CASP } & \text { Caspase } \\ \text { CCND1 } & \text { cyclin D1 } \\ \text { CD } & \text { cluster of differentiation } \\ \text { CD133 } & \text { prominin-1 } \\ \text { CDNA } & \text { complementary DNA } \\ \text { CHUK } & \text { inhibitor of nuclear factor kappa-B kinase subunit alpha } \\ \text { CNS } & \text { central nervous system } \\ \text { CS } & \text { Classical } \\ \text { Ct } & \text { cycle threshold } \\ \text { C-terminal } & \text { carboxi-terminal } \\ \text { DAB } & \text { 3'-diaminobenzidine } \\ \text { DAMP } & \text { danger associated molecular pathern } \\ \text { DAPI } & \text { 4',6-diamidino-2-phenylindole } \\ \text { DMEN } & \text { Dulbecco's Modified Eagle Medium } \\ \text { DNA } & \text { deoxyribonucleic acid } \\ \text { ECL } & \text { enhanced chemiluminescence } \\ \text { ECM } & \text { extra-cellular matrix } \\ \text { EDTA } & \text { ethylenediamine tetraacetic acid } \\ \text { ER } & \text { endoplasmic reticulum } \\ \text { EZR } & \text { ezrin } \\ \text { FADD } & \text { fas associated via death domain } \\ \text { FITC } & \text { Fluorescein } \\ \text { GAPDH } & \text { glyceraldehyde-3-phosphate dehydrogenase } \\ \text { GBM } & \text { Glioblastoma } \\ \text { GFAP } & \text { glial fibrillary acidic protein } \\ \text { GUSB } & \text { glucuronidase Beta } \\ \text { H3 } & \text { histone 3 } \\ \text { HCL } & \text { hydrochloric acid } \\ \text { HE } & \text { hematoxylin and eosin } \\ & \end{array}$




\begin{tabular}{|c|c|}
\hline HEPES & hydroxyethyl piperazineethanesulfonic acid \\
\hline HPRT & hypoxanthine phosphoribosyltransferase \\
\hline HRP & horseradish peroxidase \\
\hline hrs & Hours \\
\hline HSP & heat shock proteins \\
\hline IBA1 & ionized calcium-binding adapter molecule 1 \\
\hline ID & Identification \\
\hline $\lg G$ & immunoglobulin G \\
\hline IKBKB & inhibitor of nuclear factor kappa-B kinase subunit beta \\
\hline IL & Inteleukin \\
\hline ILS & immunolabelling score \\
\hline IRAK & interleukin 1 receptor associated kinase \\
\hline IRF & interferon regulatory factor \\
\hline JUN & proto-Oncogene C-Jun \\
\hline LPS & Lipopolysaccharide \\
\hline LY96 & lymphocyte Antigen 96 \\
\hline MES & Mesenchymal \\
\hline $\mathrm{ml}$ & Mililiter \\
\hline MLKL & mixed lineage kinase Domain Like pseudokinase \\
\hline $\mathrm{mM}$ & Milimolar \\
\hline Mops & (3-(N-morpholino)propanesulfonic acid \\
\hline mRNA & messenger ribonucleic acid \\
\hline mTOR & mammalian target of rapamycin \\
\hline MYC & avian myelocytomatosis viral oncogene homolog \\
\hline MYD88 & myeloid differentiation primary response 88 \\
\hline $\mathrm{NaCl}$ & sodium chloride \\
\hline NF1 & neurofibromin 1 \\
\hline NF-kB & nuclear factor kappa B \\
\hline ng & Nanogram \\
\hline NLRP & NLR family pyrin domain containing \\
\hline NN & non-neoplastic \\
\hline N-terminal & amino-teminal \\
\hline$p$ & Significance \\
\hline PAMP & pathogens associated molecular patherns \\
\hline $\mathrm{pb}$ & base pair \\
\hline PCR & polymerase chain reaction \\
\hline $\mathrm{pH}$ & power of hydrogen \\
\hline PI3K & phosphatidylinositol-4,5-bisphosphate 3-kinase \\
\hline PN & Proneural \\
\hline PTEN & phosphatase and tensin homolog \\
\hline PTK2 & protein tyrosine kinase 2 \\
\hline PYCARD & PYD And CARD domain containing \\
\hline qRT-PCR & quantitative reverse transcription PCR \\
\hline$r$ & Coeficient \\
\hline RB1 & retinoblastoma-associated protein \\
\hline
\end{tabular}




$\begin{array}{ll}\text { REL } & \text { V-Rel reticuloendotheliosis Viral Oncogene Homolog } \\ \text { RIPA } & \text { radioimmunoprecipitation assay buffer } \\ \text { RIPK } & \text { receptor Interacting serine/threonine kinase } \\ \text { RNA } & \text { ribonucleic acid } \\ \text { RPKM } & \text { repeats per million } \\ \text { rpm } & \text { rotations per minute } \\ \text { SCR } & \text { Scramble } \\ \text { SDS } & \text { sodium dodecyl sulfate } \\ \text { ShRNA } & \text { short hairpin RNA } \\ \text { SNC } & \text { sistema nervoso central } \\ \text { SRF } & \text { serum response factor } \\ \text { STR } & \text { short tandem repeats } \\ \text { TBP } & \text { TATA-Box Binding Protein } \\ \text { TCGA } & \text { The Cancer Genome Atlas } \\ \text { TE } & \text { Tris-EDTA } \\ \text { TICAM2 } & \text { toll like receptor adaptor molecule } 2 \\ \text { TIR } & \text { toll IL-1 receptor } \\ \text { TIRAP } & \text { TIR domain containing adaptor protein } \\ \text { TLR } & \text { toll-like receptor } \\ \text { TMA } & \text { tissue microarray } \\ \text { TRADD } & \text { TNFRSF1A associated via death domain } \\ \text { TRAF } & \text { TNF receptor-associated factor } \\ \text { TRAM } & \text { translocation associated membrane protein } \\ \text { TRIF } & \text { TIR-domain-containing adapter-inducing interferon- } \beta \\ \text { WHO } & \text { World Health Organization } \\ & \end{array}$


Table list

Table 1 Used primer sequences. 


\section{Figures list}

Figure 1 Schematic plasma membrane TLR signaling pathways. 4

Figure 2 TLR1, TLR2, TLR4, TLR5, and TLR6 expression levels in astrocytomas of different malignant grades.

Figure 3 TLR1, TLR2, TLR4, TLR5, and TLR6 expression levels in the GBM subtypes of our cohort.

Figure 4 TLR1, TLR2, TLR4, TLR5, and TLR6 expression levels in GBM molecular subtypes from TCGA dataset

Figure 5 Immunofluorescence of TLR1, TLR2, TLR4, TLR5, and $T L R 6$ in GBM cell lines.

Figure 6 TLR1, TLR2, TLR4, TLR5, and TLR6 expression levels in U87MG and A172 cell lines

Figure 7 Immunohistochemistry for TLR1, TLR2, TLR4, TLR5, and TLR6 in GBM cases.

Figure $8 T L R 1, T L R 2, T L R 4, T L R 5$, and $T L R 6$ protein expression in non-neoplastic cases and microglia and macrophages detection in GBM sample 22

Figure 9 Heatmap with major genes of the TLR signaling pathways from the TCGA dataset. 24

Figure 10 TLR4 expression. 25

Figure 11 GBM U87MG cell line proliferative profile after LPS stimulation $\quad 26$

$\begin{array}{lll}\text { Figure } 12 \text { TLR4 pharmacological inhibition. } & 27\end{array}$

Figure 13 Immunohistochemistry of sequential TMA preparations of GBM cases for IBA1 microglia marker, and TLR4. 29

Figure 14 PTEN. 32

Figure 15 Schematic proposition of the TLR canonical signaling pathway through TIRAP by PTEN regulation. 


\section{Abstract}

Moretti I.F. Toll like receptor 4 among the plasmatic membrane TLRs plays a role in Astrocytoma malignancy [dissertation]. São Paulo. "Faculdade de Medicina, Universidade de São Paulo"; 2018.

Toll-like receptors (TLRs) are the first to identify disturbances in the immune system, recognizing pathogens such as bacteria, fungi, and viruses. Since the inflammation process plays an important role in several diseases, TLRs have been considered potential therapeutic targets, including treatment for cancer. However, TLRs' role in cancer remains ambiguous. This study aims to analyze the expression levels of plasmatic cell membrane TLRs (TLR1, TLR2, TLR4, TLR5, and TLR6) in different grades (II-IV) of human astrocytoma, the most prevalent tumor of CNS. We demonstrated that TLR expressions were higher in astrocytoma samples compared to non-neoplastic brain tissue, by qRT-PCR. The genes and proteins expressions were observed in U87MG and A172 GBM cell lines, proving their presence in the tumor cells. Associated expressions between the known heterodimers TLR1-TLR2 were found in diffusely infiltrative astrocytoma. In GBM, the mesenchymal subtype showed higher levels of TLR expressions in relation to classical and proneural subtypes. Aiming to indentify the role of TLRs in tumor cells, we chose the highest TLR expressed in GBM cells, the TLR4, and performed functional assays stimulating U87MG-GBM cell line with LPS, a natural agonist for TLR4. The proliferation rate was similar in treated and non-treated cell with LPS. However, NF-kB activation was detected after $12 \mathrm{hrs}$ of LPS stimulation. When TLR4 signaling pathway was inhibited by a chemical compound (VGX-1027) a decrease in the proliferation rate was observed. Additionally, in silico analysis revealed a strong association of TLRs upregulation with increased expression level of genes related to cell cycle, inflammasome and ripoptosome pathways, further highlighting TLRs as interesting targets for cancer complementary treatment.

Descriptors: astrocytoma; glioblastoma; toll like receptors; cell proliferation; inflammation; nuclear factor - kappa B; lipopolysaccharides. 


\section{Resumo}

Moretti I.F. Receptor do tipo Toll 4 dentre os TLRs de membrana plasmática possui um papel na malignância de astrocitomas [dissertação]. São Paulo. "Faculdade de Medicina, Universidade de São Paulo"; 2018.

Os receptores do tipo Toll (TLRs) são as primeiras proteínas do sistema imune a identificarem distúrbios, reconhecem patógenos como bactérias, fungos e vírus. Como o processo inflamatório possui um importante papel em diversas doenças, os TLRs foram considerados potenciais alvos em estratégias terapêuticas, incluindo o tratamento de câncer. No entanto, o papel dos TLRs permanece ambíguo. Esse estudo teve como objetivos analisar os níveis de expressão dos TLRs presentes em membrana plasmática, TLRs (TLR1, TLR2, TLR4, TLR5, TLR6) em astrocitomas de diferentes graus de malignidade (grau II-IV), tumor mais prevalente do Sistema Nervoso Central (SNC). Nós demonstramos que a expressão dos TLRs foi mais alta em amostras de astrocitomas comparadas com tecido cerebral não-neoplásico, por qRT-PCR. A expressão gênica e proteica foi observada em células de linhagem de glioblastoma (GBM) U87MG e A172, mostrando sua presença em células tumorais. Foi observada expressão associada entre os heterodímeros TLR1TLR2. Em GBMs, o subtipo mesenquimal mostrou maior nível de expressão dos TLRs comparados aos subtipos clássico e proneural. Com o objetivo de identificar o papel dos TLRs nas células tumorais, foi selecionado dentre os TLRs o que apresentou maior nível de expressão, o TLR4, e realizamos ensaios funcionais estimulando a U87MG com LPS, um agonista natural para TLR4. A taxa de proliferação da célula tratada com LPS foi similar a não tratada. No entanto, foi observado a ativação do NF-kB após $12 \mathrm{hrs} \mathrm{do} \mathrm{estímulo}$ com LPS. Quando a sinalização do receptor foi inibida por um composto químico (VGX-1027), o nível de proliferação da U87MG decaiu. Adicionalmente, análise in silico revelou uma forte associação dos TLRs hiperexpressos com aumento da expressão de genes relacionados à sinalização do ciclo celular, inflamassoma e ripoptossoma. O que sugere serem os TLRs alvos para complementação do tratamento do câncer. 
Descriptores: astrocitoma; glioblastoma; receptores Toll-like; proliferação celular; inflamação; fator nuclear - kappa B; lipopolissacarídeos. 


\section{Introduction}

For the past decade, the inflammatory response in the tumor microenvironment has been in the spotlight due to the controversy regarding its ultimate effect. Despite the expectation that inflammation would wield a positive effect against tumorigenesis, relevant studies about the tumor-promoting effects of immune cells have been published. The resulting bioactive molecules from inflammation can provide the tumor microenvironment with growth factors that sustain proliferative signaling, with survival factors that impair apoptosis, along with proangiogenic and extra-cellular matrix-remodeling factors that facilitate invasion, metastasis, and the formation of new blood vessels (1).

Microglia are specialized cells that guarantee tissue homeostasis, in Central Nervous System. The microglia main functions are the phagocytic ability to remove dead or dying cells, preventing the tissue of an out of proportion inflammatory response $(2,3)$. Microglia has a role in regulation of neurogenesis (4-8), apoptosis (9-11), vessels formation (12-14), protection against neuronal damage (15-17), secretion of neurotrophic factors $(18,19)$, neuronal networks maturation (20), and synaptic pruning (21-25).

The homeostatic microglia have a very small soma and long branches to sense the environment, presenting a unique gene expression profile to this function $(26,27)$. When activated for an immunoinflammatory role, microglia present an unramified and ameboid form, and are proliferative and phagocytic $(22,27,28)$. The homeostatic and active states define the microglia as plastical cells. Microglia present diverse response according to tissue environment (29). Microglial proliferative response in early phase of neurodegeneration and immune response in late-phase is one example of the plasticity of these cells $(30,31)$. Also, aging microglia present decreased gene expression for axonal guidance, cell adhesion and decreased sensome phenotype which are shaped by aging brain environment $(32,33)$.

Brain tumor is known to be heterogeneous presenting non-tumor cells like neuron, astrocytes, microglia and infiltrated macrophages in addition to 
tumor cells. Interestingly, activation of microglia and macrophages may support tumor growth and my impact in the tumor biology (34). Microglia, in glioblastoma (GBM), present a pro-tumorigenic and pro-survival role due to the production of cytokines, growth factors and chemokines to attract monocytes (35-37). In the beginning of the neoplastic transformation, microglia induce tumor cells apoptosis. Some tumor cells are capable to evade the immune system and alter microglia functions to support tumor growth (38). Walentynowicz et al have observed microglia morphological transformation to phagocytic and tumor supporting profile after treatment with GBM conditioned medium (39).

Toll-like receptors (TLRs) act as the first line of defense, recognizing non self-molecules and activating inflammatory processes and their presence are classically described in immune cells (40). Therefore, TLRs have been considered as potential targets for tumor therapeutics $(41,42)$.

There are two subgroups of TLRs, based on the sub cellular location of these proteins and their respective pathogen-associated molecular pattern (PAMP) ligands. In humans, cell surface TLR1, TLR2, TLR4, TLR5, and TLR6 comprise one group, recognizing mainly microbial membrane components such as lipids, lipoproteins, and proteins. The other group consists of TLR3, TLR7, TLR8, and TLR9, which are expressed exclusively in intracellular vesicles, including endoplasmic reticulum (ER), endosomes, lysosomes, and endolysosomes, and recognizing microbial nucleic acids. TLR2 and TLR4 also identify endogenous molecules rising upon tissue injury, the damage-associated molecular patterns (DAMPs), such as heat-shock proteins, including HSP70, HSP60 Gp96, HSP22, and HSP72, and high-mobility group box-1, protein, as well as extra-cellular matrix (ECM) molecules such as biglycan, tenascin-C, versican, and fragments of ECM molecules (oligosaccharides of hyaluronic acid and heparan sulfate) (43).

Structurally, TLRs are integral membrane receptors, presenting a $\mathrm{N}$ terminal ligand recognition domain, with a leucine-rich repeat motif, a single transmembrane helix, and a C-terminal cytoplasm signaling domain-known as Toll IL-1 receptor (TIR) domain due to the homology of signaling domains of IL$1 \mathrm{R}$ family members (44). 
TLR1, TLR2, TLR4, TLR5, and TLR6 are involved in a diversity of cellular responses, ranging from cell proliferation to cell death, and as such they are the targets of the current study in astrocytomas. Cell surface TLRs may present distinct signaling pathways. Below is a brief summary of their signaling pathways and a schematic figure (Figure 1):

1) Canonical signaling pathway of plasmatic membrane TLRs involves myeloid differentiation primary response 88 (MYD88), which activates nuclear factor-kappa B (NF-kB) by a protein complex with kinases that recruit tumor necrosis factor receptor associated factor 6 (TRAF6) and leads to proinflammatory cytokines production, such as interleukin-6 (IL-6), interleukin-1 $\beta$ (IL-1 $\beta$ ) and $\alpha$, tumor necrosis factor (TNF), interleukin-8 (IL-8) and interleukin18 (IL-18). The final result of this pathway is a cell survival profile (45). NF-KB canonical activation after TLR signaling is constituted by the heterodimerization of p65 and p50 subunits. After activation of the IKB kinase, IKB is phosphorylated, ubiquitinated, and degraded by the proteasome that enables NF-KB translocation to nucleus, triggering transcriptional activity $(46,47)$. Several of such activated transcripts lead to the up regulation of positive regulators for cell cycle as cyclin D1, with a fundamental role in cellular division and DNA synthesis (48), C-Myc, responsible for enhancing expression of genes related to proliferation $(49,50)$, c-Jun $(51)$, and serum response factor (SRF) $(52,53)$.

2) Pathway through TLR2 dimerization with TLR1 or TLR6. TLR2 can form a heterodimer complex with both TLR1 and TLR6 when activated. The heterodimerization of TLR2 with TLR1 or TLR6 expands the ligand spectrum, enabling the innate immune system to recognize different structures of pathogens associated molecular patterns. The downstream signal pathways remain the same for both heterodimers (54).

3) Pathway through TLR4 endocytosis, independent of MyD88, activating TIR-domain-containing adapter-inducing interferon- $\beta$ (TRIF), with interferon type 1 response (55).

4) Pathway through TLR4 activating ripoptosome complex formation, composed of receptor-interacting serine/threonine kinase 1 and 3 (RIPK1/3) and mixed lineage domain kinase like pseudokinase (MLKL), tumor necrosis 
factor receptor type 1-associated death domain protein (TRADD), and fasassociated protein with death domain (FADD). Ripoptosome activation can lead to apoptosis when caspase 8 (CASP8) is present, or to necroptosis when it is absent. TLR5 and TLR2 are indirectly involved in ripoptosome activation by TNF secretion (56-58).

5) Pathway through TLR4, TLR2, and TLR5 forming inflammasome complex, with the production of Caspase-1 and the pro-inflammatory cytokines IL-1 $\beta$ and IL-18. The inflammasome complex is constituted by NLR family pyrin domain containing 3(NLRP3), PYD and CARD domain containing (PYCARD), and procaspase 1 (pro-CASP1) $(59,60)$.

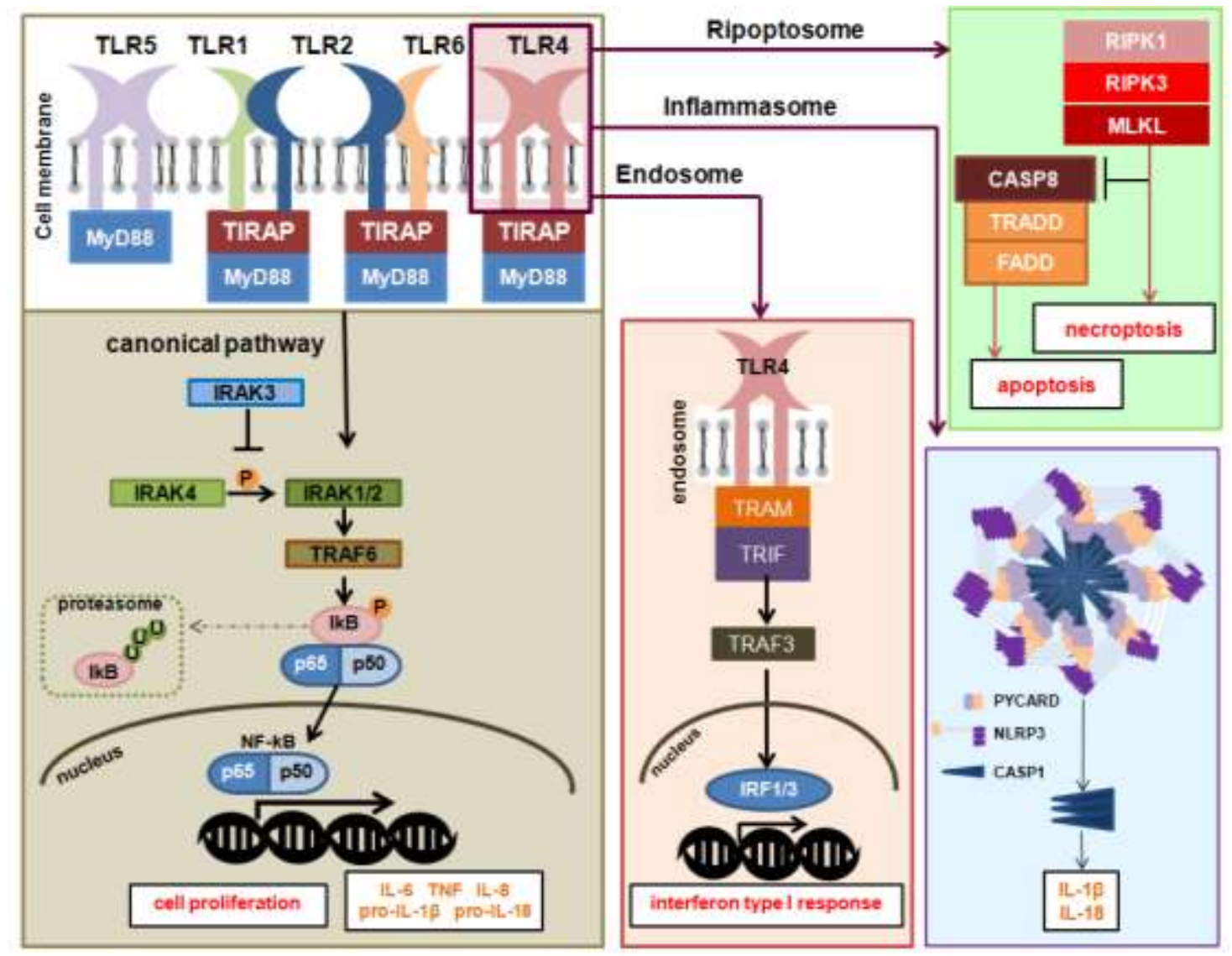

Figure 1. Schematic plasma membrane TLR signaling pathways. 1) TLR canonical signaling pathway involves MYD88 that activates, trough a signaling cascade, NF-KB and leads to pro-inflammatory cytokines production, such as IL-6, TNF, IL-8, IL-1 $\beta$ and IL1- $\alpha$ and IL-18 resulting in cell proliferation and cell survival profile. 2) TLR4 endocytosis by endosome complex signals through TIR-domain-containing adapterinducing Interferon- $\beta$ (TRIF), culminating in interferon type I secretion. 3) TLR4 activates the ripoptosome complex formation, which is composed of receptor RIPK $1 / 3$ and MLKL, TRADD and FADD. Ripoptosome leads to apoptosis when CASP8 is present or to necroptosis when it is absent. 4) The signal that activates TLR leading to its interaction with the ripoptosome can form an inflammasome complex, with the 
production of IL-1 $1 \beta$, and IL-18. The latter two are pro-inflammatory cytokines. The inflammasome complex is composed of NLRP3, PYCARD, and CASP1.

The present study was performed in astrocytoma, a brain tumor with an astrocytic phenotype. The 2007 World Health Organization (WHO) Classification of Tumors of the Central Nervous System (CNS) divided astrocytomas in four malignant grades, I to IV. The astrocytoma grade I also known as pilocytic astrocytoma, present no infiltrative characteristics, the tumor cells present low proliferative profile and a good outcome after the cirurgical resection. Astrocytomas grade II to grade IV are known as diffusely infiltrative tumors: astrocytoma grade II is a diffuse astrocytoma, although presenting a low proliferative level with cytological atypia, it tends to progress to higher tumor malignancy. The presence of anaplasia and mitotic activity characterize the grade III astrocytoma, known as anaplastic astrocytoma. Presence of neovascularization and/or necrosis are observed in astrocytoma grade IV, glioblastoma, which is the most frequent malignant CNS tumor, with a median overall survival of 15 months under current standard of care treatment of total macroscopic surgical resection combined to radiotherapy and chemotherapy with the alkylating agent, temozolomide $(61,62)$.

With the onset of next generation sequencing, it was possible to assess the molecular landscape characterizing GBMs. In an attempt to better elucidate the involved molecular tumorigenic processes, and to better guide the adjuvant therapeutic strategies, three main molecular patterns, associated to somewhat distinct clinical outcomes, were identified: 1) the proneural subtype with molecular markers related to progenitor neuronal cells; 2) the classical subtype with markers of proliferative cells; and 3) the mesenchymal subtype with markers of epithelial-mesenchymal transition. Patients exhibiting molecular markers for the mesenchymal subtype presented poor prognosis and the worst response to standard of care, and proneural markers showed better prognosis (63-66). The result of this initiative prompted a new WHO classification, in 2016, which partially includes molecular aspects of GBMs as segment of its official characterization (67)

This study aims to analyze the presence of $\operatorname{TLR}(1,2,4,5$, and 6) expressions in astrocytoma tumor cells and to explore in silico the signaling 
pathways under their up regulation. In particular, the phenotype alteration of U87MG-GBM cells by TLR4 activation and the involved signaling pathway was analyzed. The differential expression of TLR4 in the tumor cell and microglia compartments was explored aiming to better understand the microenvironment impact in tumor aggressiveness. 


\section{Aims}

\section{General aims:}

1) to analyze plasmatic membrane TLRs expression levels in diffusely infiltrative astrocytomas WHO grades II to IV and their presence in GBM cell lines.

2) to analyze the signaling pathways involved in TLR4 activation in U87MGGBM cell line

\section{Specific aims:}

1) to analyze the gene and protein expressions of TLR1, TLR2, TLR4, TLR5, TLR6 in astrocytomas, in GBM cases, according to molecular stratification and GBM cell lines, and to validate the findings in The Cancer Genome Atlas (TCGA) dataset.

2) to analyze the putative signaling pathways related to the TLRs in the TCGA-RNASeq dataset.

3) To analyze the TLR4 protein expression in tumor cell and microglia compartments and their modulation according to the tumor microenvironment.

4) analyze U87MG phenotype alteration after TLR4 activation by LPS.

5) to analyze TLR4 signaling pathway related to TLR4 activation by LPS stimulation through $T L R 4$ chemical inhibition.

6) to explore the impact of the microglia compartment in the TLR4 expression resulted of the astrocytoma samples. 


\section{Materials and Methods}

\subsection{Tumor samples and ethical statement}

The studied cases were composed of 140 astrocytoma grade II-IV samples, collected during therapeutic surgical intervention in the Neurology Department of the Hospital das Clinicas of University of Sao Paulo School of Medicine, by the institutional neurosurgery group. The cases were stratified according to the WHO classification as: 22 non-neoplastic (NN) cases from epilepsy surgery, 26 astrocytoma grade II (AGII) cases, 18 astrocytoma grade III (AGIII) cases, and 96 astrocytoma grade IV (GBM) cases, this cohort has been previously published $(68,69)$. The procedures were performed with informed and approved consent according to the Institutional Ethical Committee guidelines at the Hospital das Clinicas of University of Sao Paulo School of Medicine (691/05). The present study was approved by the same institution $(059 / 15)$ to use the biorepository.

\subsection{Sample preparation and RNA extraction}

The samples were macrodissected and frozen in liquid nitrogen right after the surgical removal, then cryosectioned for RNA extraction. For the tumor tissue analysis, a $6 \mu \mathrm{m}$ thick section and hematoxylin-eosin staining was made to guarantee the absence of necrotic, gliosis, non-neoplastic areas, and more than $80 \%$ of tumor cells in all tumor tissue specimens $(70,71)$.

The RNA extraction was accomplished by the RNeasy Mini Kit (Qiagen, Hilden, Germany) following the manufacturer instructions. The RNA concentration and purity were evaluated by NanoDrop, and 1.8-2.0 values for $260 \mathrm{~nm}$ and $280 \mathrm{~nm}$ absorbance ratios were considered satisfactory. RNA quality was checked by electrophoresis in agarose gel. Reverse transcription was performed with $1 \mu \mathrm{g}$ of RNA treated with DNase I (FPLC-puro, GE Healthcare, Uppsala, Sweden), and amplified with random primers and oligodT 
oligonucleotides, RNase inhibitor, and the SuperScript III reverse transcriptase (Thermo Fisher Scientific, Carlsbad, CA), following the manufacturer instructions. Finally, the cDNA was treated with RNase $H$ (GE Healthcare, Uppsala, Sweden), diluted in TE (Tris/EDTA) buffer and stored at $-20^{\circ} \mathrm{C}$ for posterior use by quantitative real-time PCR (qRT-PCR) analysis.

\subsection{Quantitative Real-Time PCR (qRT-PCR)}

TLR1, TLR2, TLR4, TLR5, and TLR6 mRNA levels were evaluated by qRT-PCR, using Power SYBR Green. The results were normalized with the geometrical mean of three reference genes for each sample, as previously described (72): hypoxanthine phosphoribosyltransferase (HPRT), glucuronidase beta (GUSB), and TATA box-binding protein (TBP). The primers were designed to amplify $80-120 \mathrm{pb}$, with melting temperature around $60^{\circ} \mathrm{C}$ and synthesized by Exxtend (Campinas, Brazil) and IDT (Coralville, IA). The primers were designed as described in Table 1.

\section{Table 1. Used primer sequences}

\begin{tabular}{lll}
\hline Gene & forward primer (5'-3') & reverse primer (5'-3') \\
\hline TLR1 & GGCACCCCTACAAAAGGATC & GATAATGGCAAAATGGAGATGCT \\
TLR2 & TGTGGGTTGAAGCACTGGAC & TTGCGGTCACAAGACAGAGAAG \\
TLR4 & TTTATCCAGGTGTGAAATCCAGAC & TCCAGAAAAGGCTCCCAGG \\
TLR5 & CATACTCCTGATGCTACTGACAACG & GCAGATGAGAGTAGGGAAGTCCA \\
TLR6 & AAACGGCACATTCTTCCACAA & TTTGTCGTTGTTGTTACTGTGGTTG \\
\hline Reference gene & & \\
\hline HPRT & TGAGGATTTGGAAAGGGTGT & AGCACACAGAGGGCTACAA \\
GUSB & GAAAATACGTGGTTGGAGAGCTCATT & CGAGTGAAGATCCCCTTTTTA \\
TBP & AGGATAAGAGAGCCACGAACCA & CTTGCTGCCAGTCTGGACTGT \\
\hline
\end{tabular}

Primers were optimized to the minimum concentration for the minor cycle threshold (Ct), the maximum amplification efficiency, and minimum nonspecific amplifications. The mix was composed by cDNA $(3 \mu \mathrm{l})$, Power SYBR Green PCR Master Mix (Thermo Fisher Scientific, Carlsbad, CA) $(6 \mu \mathrm{l})$, and the reverse and forward primers ( $3 \mu$ l of each). The qRT-PCR was done in duplicate using the ABI Prism 7500 (Thermo Fisher Scientific, Carlsbad, CA) following the protocol: 2 minutes at $50^{\circ} \mathrm{C}, 10$ minutes in $95^{\circ} \mathrm{C}$, and 40 cycles of 15 seconds at 
$95^{\circ} \mathrm{C}$, and 1 minute at $60^{\circ} \mathrm{C}$. The expression values were assessed by the formula $2^{-\Delta \mathrm{Ct}}$ as $\Delta \mathrm{Ct}$ is: the $\mathrm{Ct}$ of analyzed gene - geometric mean $\mathrm{Ct}$ of the reference genes.

\subsection{Immunofluorescence}

The presence of TLR proteins in tumor cells was analyzed by immunofluorescence. A172 and U87MG human GBM cell lineages were acquired from ATCC and authenticated by short tandem repeats (STR) analysis using GenePrint 10 System (Promega, Madison, WI). Cells were cultured in monolayer with DMEM medium (Dulbecco's Modified Eagle's Medium, (Thermo Fisher Scientific, Carlsbad, CA), $10 \%$ fetal bovine serum and $100 \mu \mathrm{g} / \mathrm{ml}$ streptomycin and $100 \mathrm{IU} / \mathrm{ml}$ penicillin.

Cells were fixed with methanol and acetone (1:1), the membrane was permeabilized with Triton-X-100 $(0.1 \%)$, and, to avoid unspecific reactions, the cells were treated with $2 \%$ bovine serum albumin. The primary antibodies antiTLR1 (ab180798, rabbit polyclonal, 1:400 diluted), anti-TLR2 FITC-conjugated (AB_945852, ab59711, mouse monoclonal, 1:50 diluted), anti-TLR4 (AB_446735, ab22048, mouse monoclonal 1:200 diluted), anti-TLR5 (AB_793183, sc-57461, mouse monoclonal, 1:50 diluted, Santa Cruz, CA), and anti-TLR6 (AB_2205406, ab37072, rabbit polyclonal, 1:50 diluted) (Abcam, Cambridge, UK) were incubated overnight at $4^{\circ} \mathrm{C}$. The secondary antibodies (Thermo Fisher Scientific, Carlsbad, CA) goat anti-Rabbit IgG H\&L (Alexa Fluor 568) and goat anti-Mouse IgG H\&L (Alexa Fluor 568 and 488) were incubated for one hour, and nuclei were stained with DAPI (Thermo Fisher Scientific, Carlsbad, CA). The preparations were analyzed in confocal microscopic Zeiss 510 LSM META and Zeiss 780-NLO (Thornwood, NY). The retrieved images were analyzed by Image J/Fiji (73).

\subsection{Immunohistochemistry}

Paraffin embedded tissue of five representatives cases of GBM, and five non-neoplastic brain tissue from surgical epilepsy cases were stained for the 
five TLRs, IBA1, CD68 and GFAP by immunohistochemistry using the Novolink kit (Novolink; Novocastra, Newcastle-upon-Tyne, UK), following the manufacture guide. The sections were processed to antigen retrieval, by citrate buffer (10mM, pH6.0) for 3 minutes at $122^{\circ} \mathrm{C}$, using an electric cooker (BioCare Medical, Walnut Creek, USA). After protein blocking, the tissue was incubated with antibodies: anti-TLR1(ab180798, rabbit polyclonal, 1:800 diluted), antiTLR2 (AB_307008, ab9100, mouse monoclonal, 1:50 diluted), anti-TLR4 (AB_446735, ab22048, mouse monoclonal 1:800 diluted), anti-TLR5 (AB_793183, sc-57461, mouse monoclonal, 1:500 diluted, Santa Cruz, CA), anti-TLR6 (AB_2205406, ab37072, rabbit polyclonal, 1:200 diluted) (Abcam, Cambridge, UK), anti-CD68 (AB_2687454, M0718, mouse monoclonal, 1:1600 diluted, DAKO, CA), anti-IBA1 (AB_2224403, ab15690, mouse monoclonal, 1:700 diluted, Abcam, Cambridge, UK), anti-GFAP (AB_10013382, Z0334, rabbit polyclonal, 1:600, DAKO, CA) at $20^{\circ}$ for 16 hours. The reaction performed by the kit uses diaminobenzidine (DAB), and for nuclear staining Harris hematoxylin was used. To obtained optimal dilution tonsil sections was used. The immunoreactions for the five TLRs were analyzed according to a semi-quantitative score system considering the intensity of staining (0: negative, 1: weak, 2: moderate and 3: strong), and percentage of immune-positive cells (0: no cells stained, $0.5: 1-10 \%, 1: 10-25 \%, 2: 26-50 \% 3: 51-75 \%$ and $4: 76-$ $100 \%$ ). An immunolabeling score (ILS) was obtained by the product of the intensity of staining and the percentage of stained cells, by two independent investigators (IFM, SKNM), and simultaneous revision were performed to obtain the final score in case the concordance was not achieved. Digital photomicrographs of representative fields were captured and processed using Adobe Illustrator CS6 (Adobe System, San Jose, CA).

\subsubsection{Immunohistochemistry in tissue microarray (TMA)} preparations

Three representative areas of the core of each tumor tissue were extracted with diameter of $0.6 \mathrm{~mm}$ using an array machine (MTA-1, Beecher Instruments Inc., Sun Prairie,WI, USA). A TMA block was produced by the 
insertion of the cores in predetermined areas and produced $3 \mu \mathrm{m}$ thickness sections that was paraffin coated and store in $-20^{\circ} \mathrm{C}$ until use (74). The tissue cohort is composed of 142 GBM cases.

For TMA sections, the immunohistochemistry was performed as described above and prepared with anti-TLR4 (AB_446735, ab22048, mouse monoclonal 1:800 diluted) and anti-IBA1 (1:1000 diluted, 019-19741 Wako Chemicals USA, Inc.).

\subsection{TLR4 activation in U87MG cell}

U87MG cells were stimulated with lipopolysaccharide (LPS) from Escherichia coli O127:B3 (Sigma-Aldrich, St. Louis, MO, USA) a known agonist for TLR4 (75). For the proliferation assays the concentration used was $1 \mu \mathrm{g} / \mathrm{ml}$, $10 \mu \mathrm{g} / \mathrm{ml}$ and $100 \mu \mathrm{g} / \mathrm{ml}$ and the stimulation was done for up to 96 hours. An optimal concentration of $10 \mu \mathrm{g} / \mathrm{ml}$ was chosen for the following assays: TLR4 inhibition by chemical compound and NF-kB activation assay.

\subsection{Cellular proliferation assay}

U87MG cells were plated in 96 wells $\left(2 \times 10^{3}\right.$ cell/well), stimulated in three different concentrations of LPS $1 \mu \mathrm{g} / \mathrm{ml}, 10 \mu \mathrm{g} / \mathrm{ml}$ and $100 \mu \mathrm{g} / \mathrm{ml}$ and compared to non-stimulated group. All groups were evaluated in sextuplicate. The plates were observed in four time periods of $24 \mathrm{hrs}$, 48hrs, $72 \mathrm{hrs}$ e $96 \mathrm{hrs}$. The cell proliferation was analyzed by the Presto Blue reagent (Thermo Fisher Scientific, Waltham, MA, US), following the manufacture instructions. An additional spot with only the Presto Blue reagent was evaluated and used to normalize the fluorescence results. The fluorescence of each well was measured by the Glomax (Promega, Madison, WI, US). Presto Blue reagent is a reasozurin based assay, it indicates the cell viability by the ability of living cell to reduce the non-fluorescent blue dye to resorufin, a red highly fluorescent component.

\subsection{NF-kB translocation to nucleus}


To analyzed NF-kB activation by TLR4 stimulation, the translocation of the subunit p65 to nucleus was evaluated by Western Blot. Cytoplasm and nuclear protein extractions were performed of U87MG cells after LPS treatment. The cells were lysed with a buffer solution containing light detergents to separate the cytoplasm proteins: Igepal-CA-630 (0.5\%) (Sigma Aldrich, St. Louis, EUA), Triton X-100 (0.25\%) (Sigma Aldrich, St. Louis, US), Glycerol (10\%) (Thermo Fisher Scientific, Waltham, MA, US), $1 \mathrm{mM}$ EDTA, 50mM Hepes, $140 \mathrm{mM}$ de $\mathrm{NaCl}$. After centrifugation, nuclei were lysed with a buffer containing strong detergent and sonicated with $50 \mathrm{mM}$ Tris- $\mathrm{HCl}, 10 \mathrm{mM}$ EDTA e SDS (1\%). For the Western Blotting, $40 \mu \mathrm{g}$ of protein was loaded in each lane of $4-12 \%$ polyacrylamide gel (Invitrogen, Carsbald, CA, US), in a buffer solution NuPAGE MOPS SDS (Invitrogen, Carsbald, CA, US). The proteins were transfered electrophoretically to a polyvinylidene fluoride membrane through the TransBlot ${ }^{\circledR}$ SD semi-dry system (Trans-Blot $\circledast$ Transfer Cell, Biorad, Hercules, CA, US). For the protein identification, p65 (Abcam, ab32536, Cambridge, UK, 1:500 dilution) and Histone $\mathrm{H} 3$ total (ab12079, Abcam, Cambridge, UK, 1:20000) antibodies were used. The secondary antibodies were anti-rabbit and anti-goat (Sigma-Aldrich, St. Louis, MO, EUA). The bands were revealed by the chemiluminescent reagent ECL (Western Lightning Chemiluminescence Reagent Plus, Perkin Elmer, Waltham, MA, US) in the ImageQuant LAS4000 (GE Healthcare, Little Chalfont, UK).

\section{9. TLR4 chemical inhibition}

TLR4 was also blocked by a commercial immune modulator VGX-1027 (Git-27) (Abcam, Cambridge, RU) currently used for the treatment of immunemediated inflammatory diseases (76). $1 \mu \mathrm{M}$ of this compound from a previous $1 \mathrm{mM}$ dilution in ethanol was used for the inhibition assays.

\subsection{Statistical analysis}

The statistical analysis was performed in the program SPSS version 23.0 (IBM, Armonk, NY). The data distribution was evaluated by Kolmogorov- 
Smirnov test. The non-parametric results were evaluated by Kruskal-Wallis test, followed by post hoc Dunn's test. The correlations between each two receptors gene expression levels were assessed by Spearman-rho. The associations are considered strong when $r \geq 0.7$, moderate when $0.4<r>0.7$, and low when $r \leq$ 0.4. Differences were considered significant for $p<0.05$.

The GBM RNAseq dataset from The Cancer Genome Atlas (TCGA http://cancergenome.nih.gov/) was downloaded from *.rsem.genes.normalized_ results address. The data was analyzed by DE-seq and the RPKM values were normalized by the z-score.

For the proliferation assay was performed the test Two-way Anova followed by the post hoc test Bonferroni. Differences were considered significant for $p<0.05$. 


\section{Results}

\subsection{TLR1, TLR2, TLR4, TLR5, and TLR6 mRNAs were up-regulated in diffuse astrocytomas}

Genes coding the five receptors was analyze by qRT-PCR, TLR1, 2, 4, 5, and 6, and presented higher expression levels in astrocytoma samples compared to non-neoplastic brain tissues, with statistical significance $(p<0.05)$ (Figure 2A). Only TLR2 expression in AGll did not present any statistical difference compared to $\mathrm{NN}$ tissue, in contrast to the statistical difference observed in AGIII and GBM ( $p<0.05)$. TLR1, TLR2, and TLR6 mRNA expression median values showed an increase in parallel to the increase of malignancy. On the other hand, the median TLR4 expression in GBM cases was lower than in the other astrocytoma grades (AGII-AGIII).

\subsection{Associated TLRs expressions were observed in GBM}

The correlation between each gene was analyzed. All TLRs expressions were correlated between themselves in GBM, with statistical significance of $p<$ 0.05 (Figure 2B). Expression levels of TLR2 and TLR1 presented the strongest correlation ( $r=0.8448, p<0.0001$ by Spearman-rho test). The correlation indicates the activation and heterodimerization for TLR1 and TLR2 in the tumor tissue. 


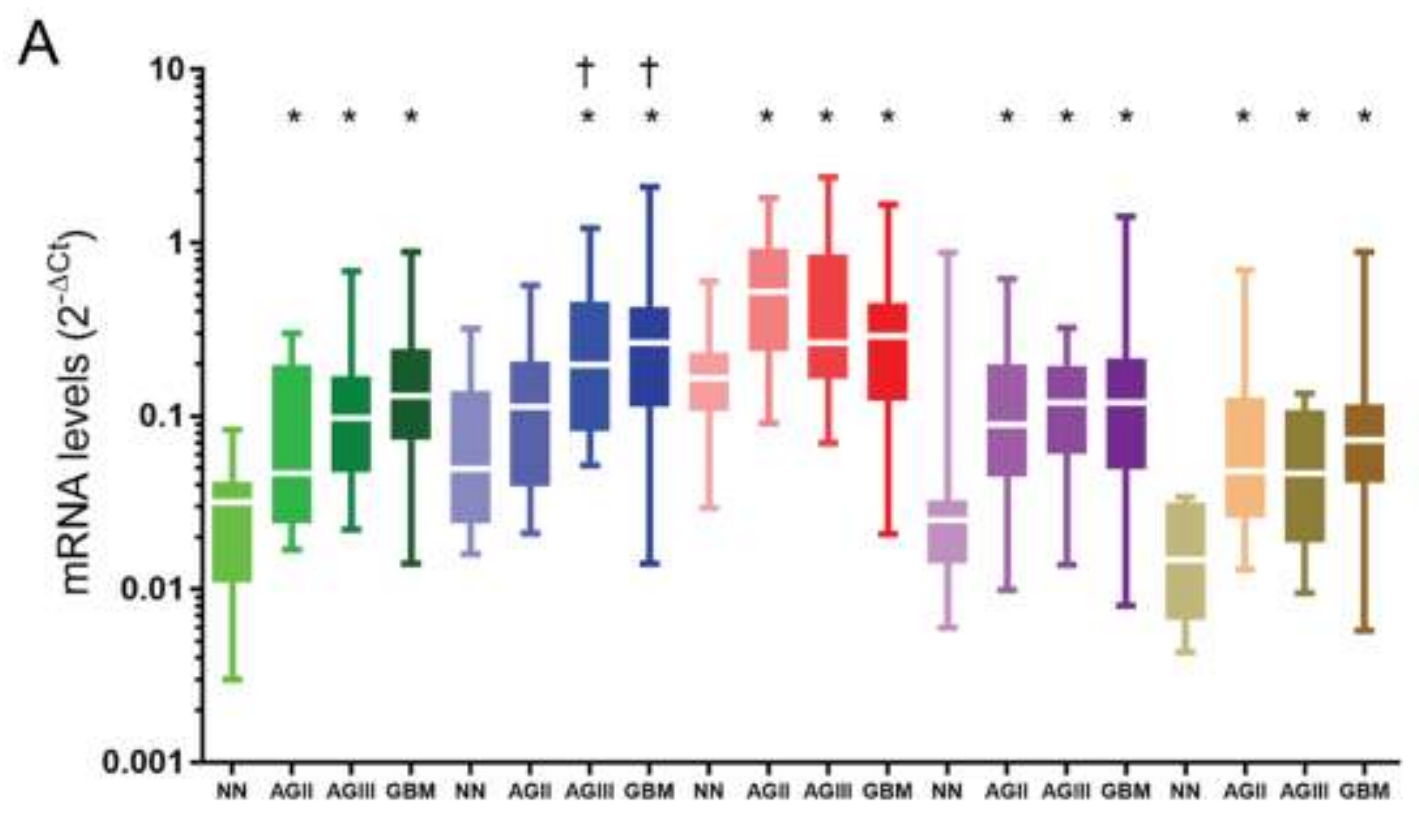

B
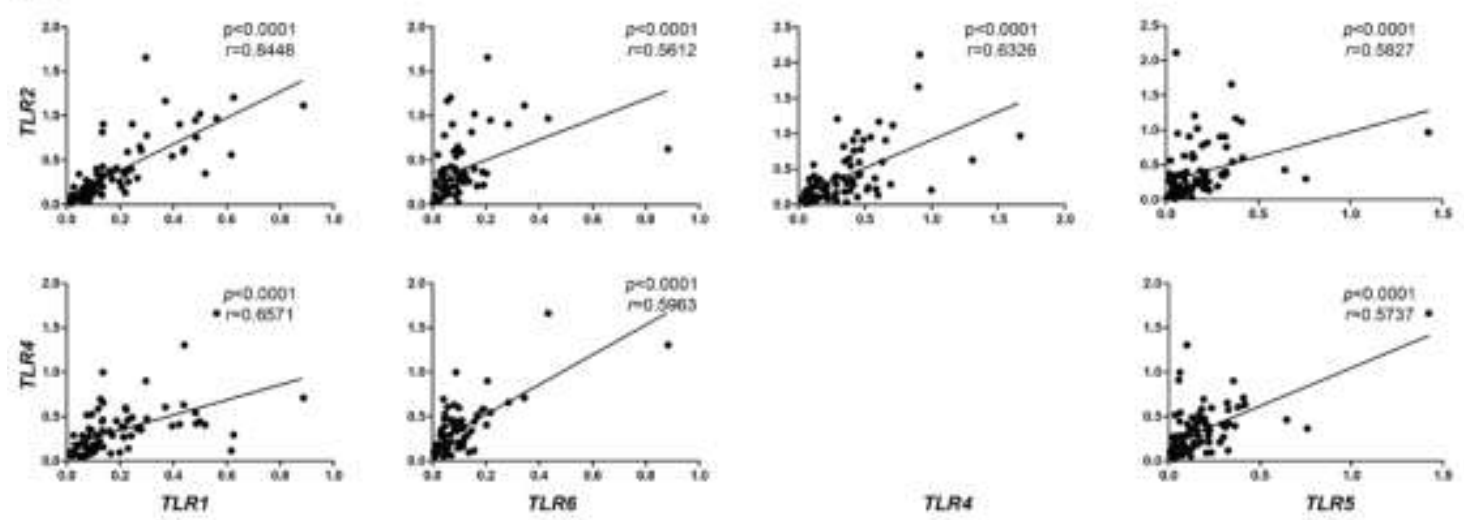

Figure 2. TLR1, TLR2, TLR4, TLR5, and TLR6 expression levels in astrocytomas of different malignant grades. (A) The analyzed samples consisted of 22 non-neoplastic (NN) cases, 26 astrocytoma grade II (AGII) cases, 18 astrocytoma grade III (AGIII) cases, and 96 glioblastoma (GBM) cases. Data are represented by box and whisker plots, with the median represented by the line in the middle of the boxes, and top and bottom boxes represent the first and third quartiles. QRT-PCR values are normalized by three housekeeping genes (HPRT, GUSB, TBP). For statistical analysis, KruskalWallis and Dunn's tests were applied, wherein $\left(^{*}\right) p<0.05$ when compared to NN cases and $(\dagger) p<0.05$ when compared to AGll (Dunn test), all the genes present $p<0.01$ (Kruskal-Wallis). (B) Correlation between TLR2-TLR1, TLR2TLR6, TLR2-TLR4, TLR2-TLR5, TLR4-TLR1, TLR4-TLR5, and TLR4-TLR6 are demonstrated in GBM cases. Statistical analysis was made by the Spearmanrho correlation, and $p<0.05$ were considered significative.

\subsection{Higher TLR4 and TLR6 median expression levels were observed in} mesenchymal GBM compared to other molecular subtypes 
The analysis of TLRs expression levels for GBM molecular subtypes showed that mesenchymal GBM subtype presented higher TLR4 and TLR6 mRNA median levels than other molecular subtypes in our cohort (Figure 3) (77). However, given the reduced sample number, particularly for the proneural and mesenchymal GBM cases in this cohort, statistical significance was not achieved. Therefore, we performed a similar analysis in molecular GBM subtypes of TCGA public dataset. In this larger cohort, all five TLRs presented higher expression in mesenchymal subtype with statistical significance compared to proneural and classical subtypes (Figure 4).

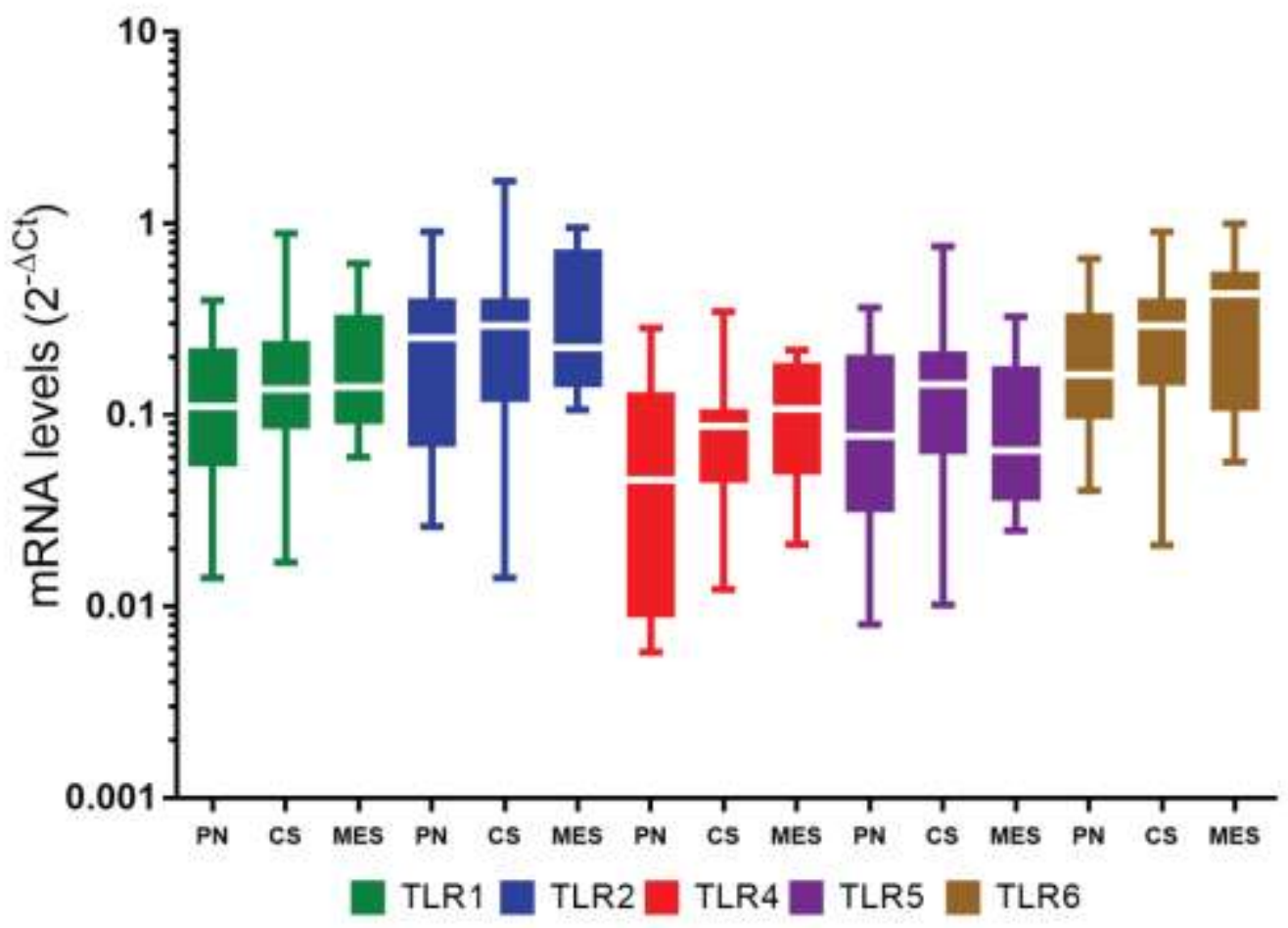

Figure 3. TLR1, TLR2, TLR4, TLR5, and TLR6 expression levels in the GBM subtypes of our cohort composed of 14 proneural (PN), 38 classical (CS) and 16 mesenchymal (MES) subtype cases. Horizontal bars indicate the mean value of each group. 


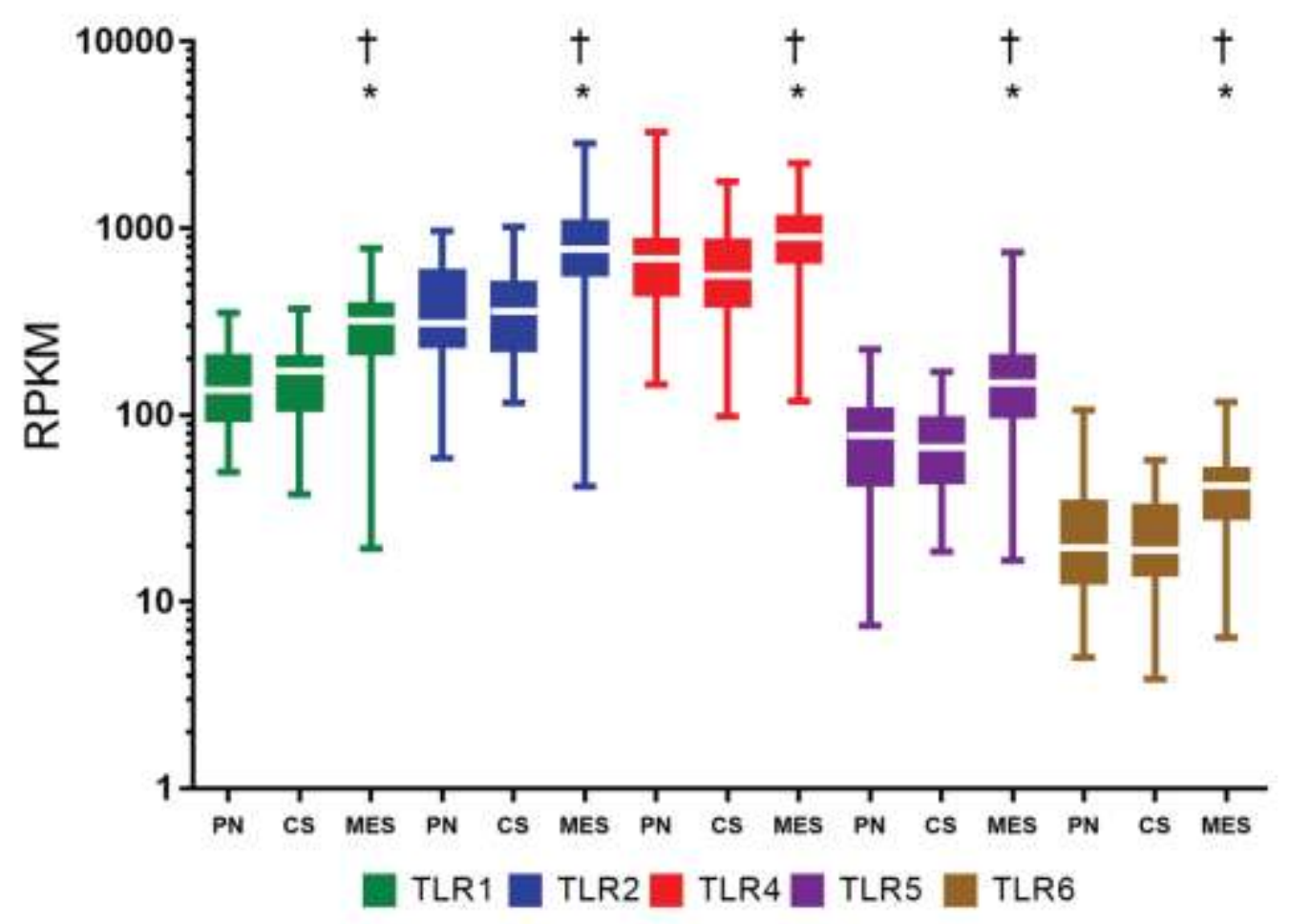

Figure 4. TLR1, TLR2, TLR4, TLR5, and TLR6 expression levels in GBM molecular subtypes from TCGA dataset. Data are represented by box and whisker plots, with the median represented by the line in the middle of the boxes, and top and bottom boxes represent the first and third quartiles. The dataset was divided into 37 proneural (PN) cases, 40 classical (CS) subtype cases, and 55 mesenchymal (MES) subtype cases, in which $\left(^{*}\right)$ and $(\dagger)$ are $p<$ 0.05 when mesenchymal group was compared to proneural cases and to classical cases, respectively (Dunn's test) and $p<0.01$ (Kruskal-Wallis).

\section{4. $T L R 1, T L R 2, T L R 4, T L R 5$, and $T L R 6$ were present in tumor cell lines}

Aiming to identify the distribution of the TLR proteins in specific cell compartment we performed an immunofluorescence in pure tumor cells of two GBM cell lineages, U87MG and A172. The five TLR proteins were identified in the cells, both GBM cell lineages with mutational status consistent for the mesenchymal subtype (U87MG and A172): RB transcriptional co repressor (RB1) missense mutation in $A 172$, and neurofibromin (NF1) missense and deletion mutation in U87MG (78). For the immunofluorescence observation (Figure 5), TLR5 presented lower protein expression in U87MG compared to A172. The evaluation of these TLR mRNA levels by qRT-PCR corroborated 
their presence in both cell lineages; TLR5 mRNA expression level was not detected in U87MG cells by qRT-PCR (Figure 6).

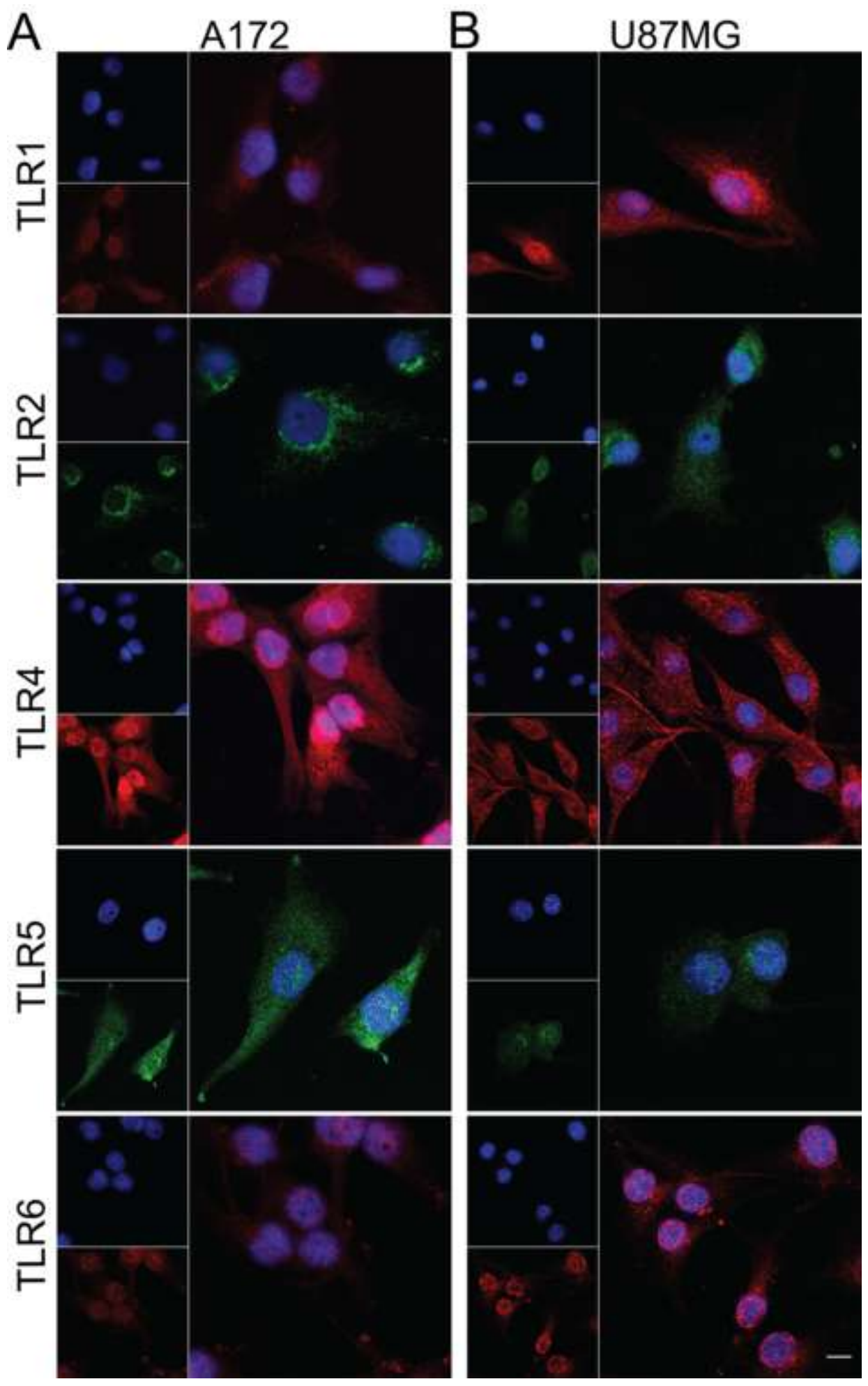

Figure 5. Immunofluorescence of TLR1, TLR2, TLR4, TLR5, and TLR6 in GBM cell lines. A172 (A) and U87MG (B). TLR1, TLR4, and TLR6 are stained in red, TLR2 and TLR5 in green, and nuclei in blue by DAPI. The presence of all five TLRs was detected in both cell lines. Expression of TLR5 was more intense 
in A172 compared to U87MG. TLR4 and TLR5 positivity were detected in both tumor lineage cells nuclei. Magnification of 400x.

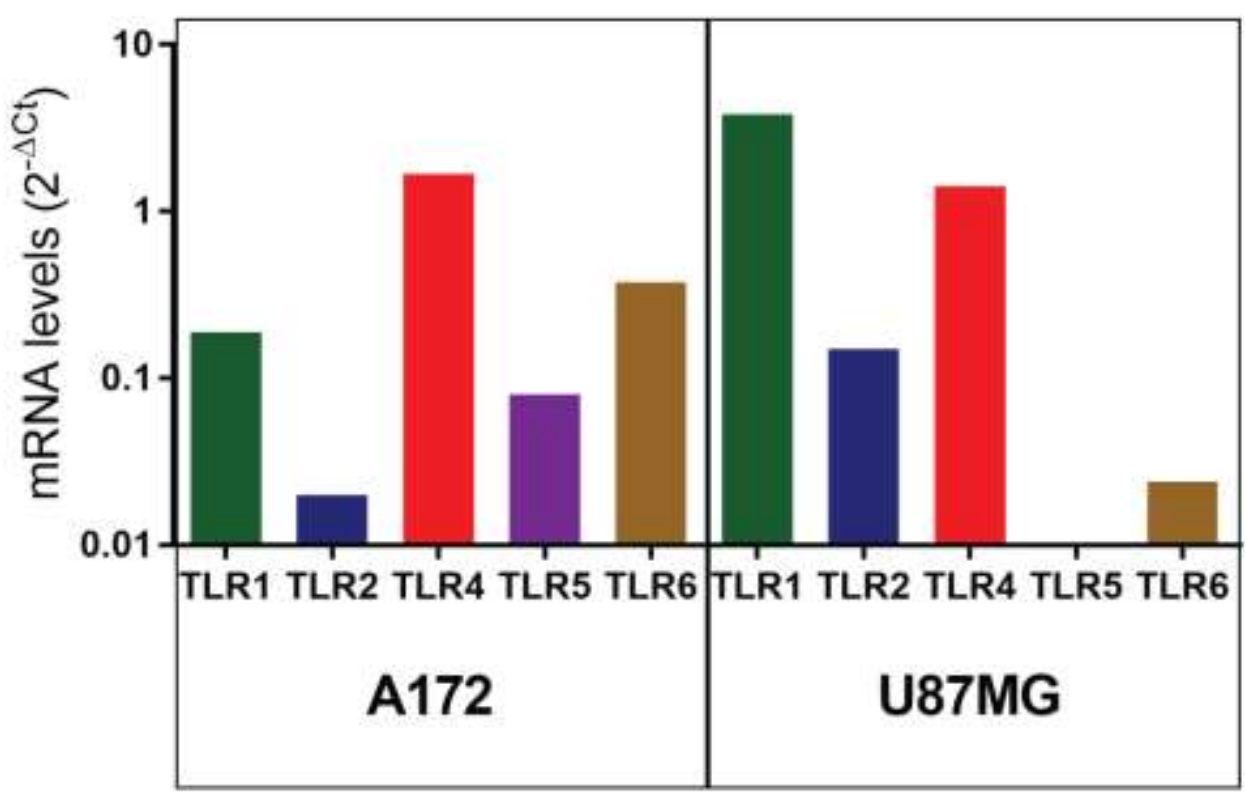

Figure 6. TLR1, TLR2, TLR4, TLR5, and TLR6 expression levels in U87MG and $\mathbf{A 1 7 2}$ cell lines. Heterogeneity in the distribution of the five TLRs is observed between the cell lines, although both GBM cell lines present somatic mutation profiles of mesenchymal subtype. TLR4 expression is high in both cell lines, whereas TLR5 is undetectable in U87MG cell line.

\section{5. $T L R 1, T L R 2, T L R 4, T L R 5$, and $T L R 6$ protein presence in GBM tissue}

The five TLRs proteins were detected, by immunohistochemistry, in phenotypically GBM cells in all cases, including on the multinucleated GBM cells (Figure 7), corroborating the findings observed in the GBM cell lineages. The TLR4 protein expression was the highest among the five studied TLRs. Interestingly, TLR4 and TLR5 protein expressions were also observed in tumor cell nuclei, as observed in the immunofluorescence preparations of the GBM cell lineages (Figure 5). The presence of few microglia in the GBM tumor sample were detected by IBA1 staining and few macrophages with $\mathrm{CD} 68$, which did not overlap with the TLRs positive tumor cells. The positive reaction for GFAP was consistent with the glial origin of the analyzed GBM tumor samples (Figure 8). Non-neoplastic brain samples were also stained for TLRs. As expected, the positivity for these receptors was observed in neurons and the 
lowest expression was for TLR2. Similar to the staining pattern in tumor cells, TLR5 positivity was detected in neuron nuclei (Figure 8).

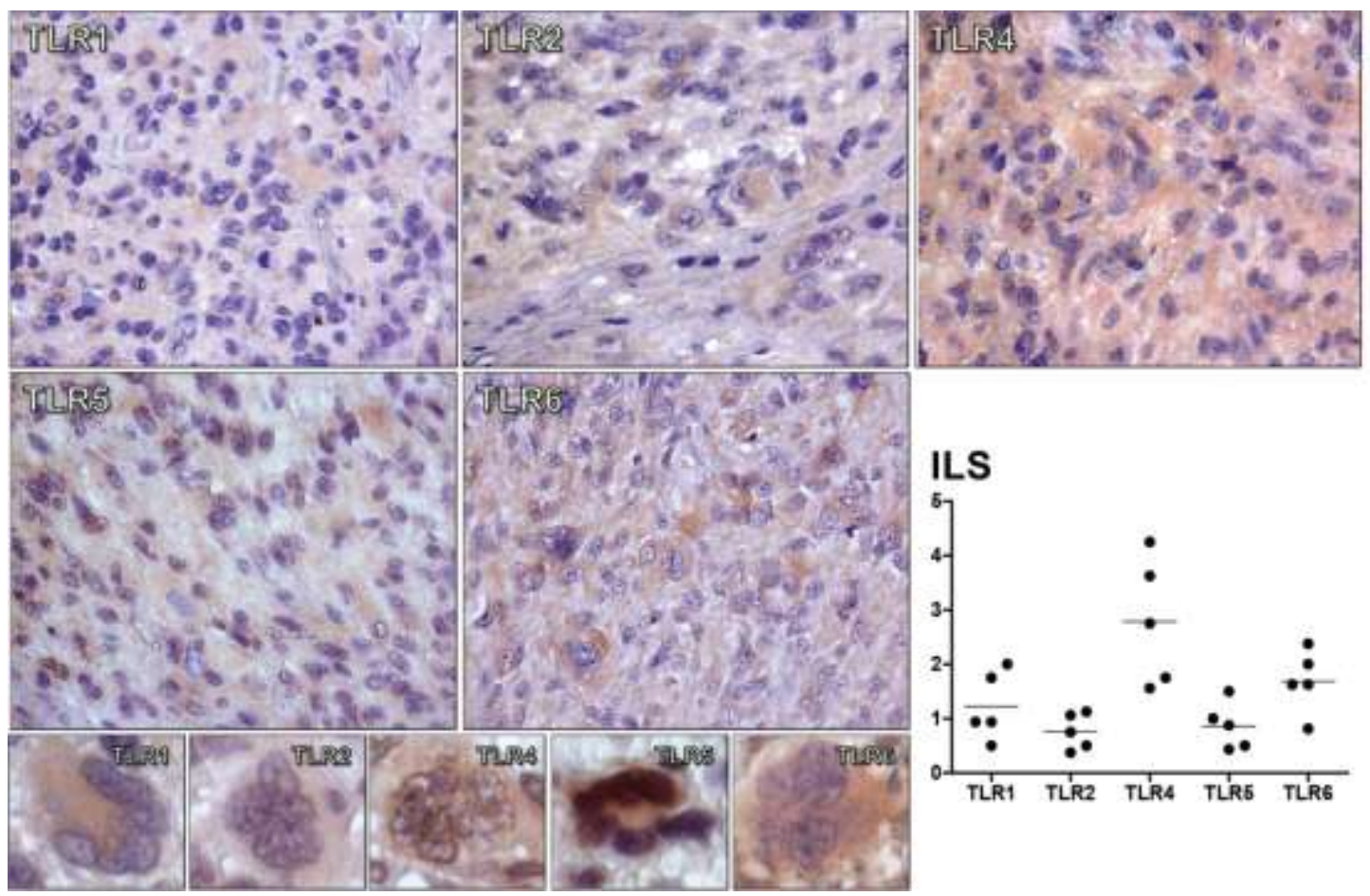

Figure 7. Immunohistochemistry for TLR1, TLR2, TLR4, TLR5, and TLR6 in GBM cases. Positive immunolabeling of GBM tumor cells for TLRs are demonstrated at $600 x$ magnification of tumor tissues, and at $800 x$ magnification in a multinucleated GBM tumor cell. The distribution of the Immunolabeling score (ILS) for these TLRs in five GBM cases was presented as a dispersion graph, where the black dots represent the mean ILS obtained by the two independent investigators for each individual tumor case, and the horizontal bar represent the mean ILS for each receptor. TLR4 and TLR5 positive staining were detected in tumor nuclei. 


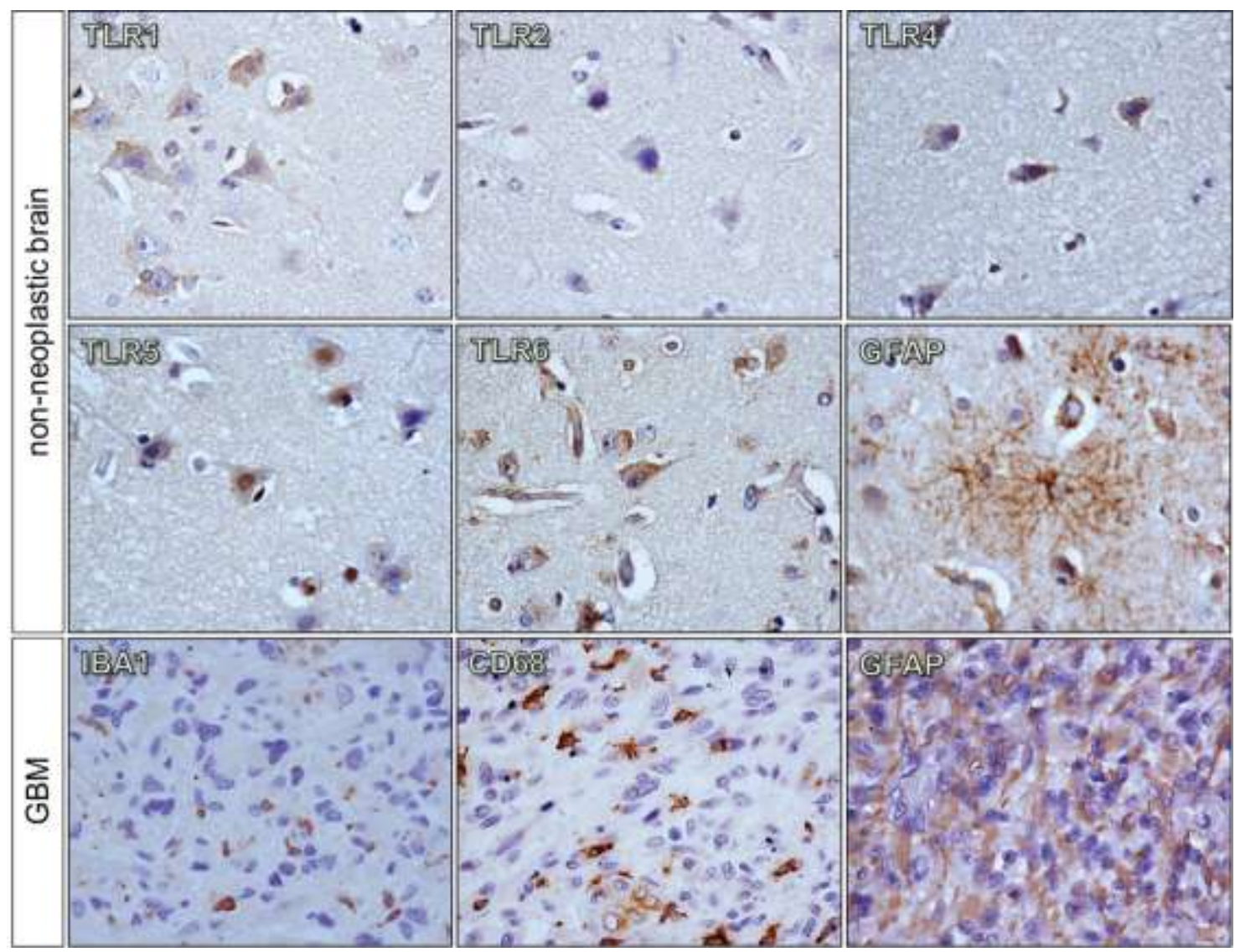

Figure 8. TLR1, TLR2 TLR4, TLR5, and TLR6 protein expression in nonneoplastic cases and microglia and macrophage detection in GBM sample. Immunohistochemistry for a representative non-neoplastic case stained for TLR1, TLR2, TLR4, TLR5, TLR6 and GFAP for glial cell identification. Presence of few microglia in the same GBM sample present previously was observed by IBA1 staining, and also few macrophages was detected by CD68 staining. GFAP positivity was shown in the GBM tumor sample confirming the glial origin of the tumor.

\subsection{In silico exploration of TLR signaling pathway}

A heatmap including selected target genes of TLR signaling pathways was built from the TCGA RNAseq dataset, identifying up- and down-regulated genes for each GBM subtype (Figure 9). The RPKM values (Attachment 1 Supporting information Figure) were normalized by the z-score values for each gene to allow comparative analysis among them. In silico analysis highlighted the higher expression of TLRs in mesenchymal subtype relative to proneural and classical subtypes (Figure 4), and pointed out a downstream up-regulation through MYD88/TIRAP and NF-KB, ending with increased expression levels of 
genes that code for cytokines and genes related to cell proliferation. Particularly, expression levels of genes that code for IL-8, IL-6, IL-1 1 , IL-1 1 , and IL-18 were differentially increased in the mesenchymal GBM subtype compared to the other two subtypes (Attachment 1 - Supporting information Figure). Moreover, RELA, which codes for the nuclear subunit of NF-KB, presented positive correlations $(p<0.05)$ by Spearman-rho test with expression levels of cell proliferation genes: JUN $(r=0.422$ and $r=0.536)$ and $\operatorname{SRF}(r=0.462$ and $r$ $=0.577$ ) and in mesenchymal and classical subtypes, respectively. In contrast, the gene expressions related to interferon type I response presented low or undetermined z-score values (not shown). Interestingly, expression levels of genes involved in ripoptosome signaling, such as RIPK3 and $M L K L$, were also comparatively increased in mesenchymal GBM subtype, and their values correlated to $\operatorname{TLR2}$ ( $r=0.795$ and $r=0.661$, respectively), and to TLR4 ( $r=$ 0.575 and $r=0.360$, respectively). Of note, PYCARD, NLRP3 and CASP1, which participate in the inflammasome pathway, presented higher expression levels in mesenchymal subtype of GBM compared to the other two subtypes (Attachment 1 - Supporting information Figure). 


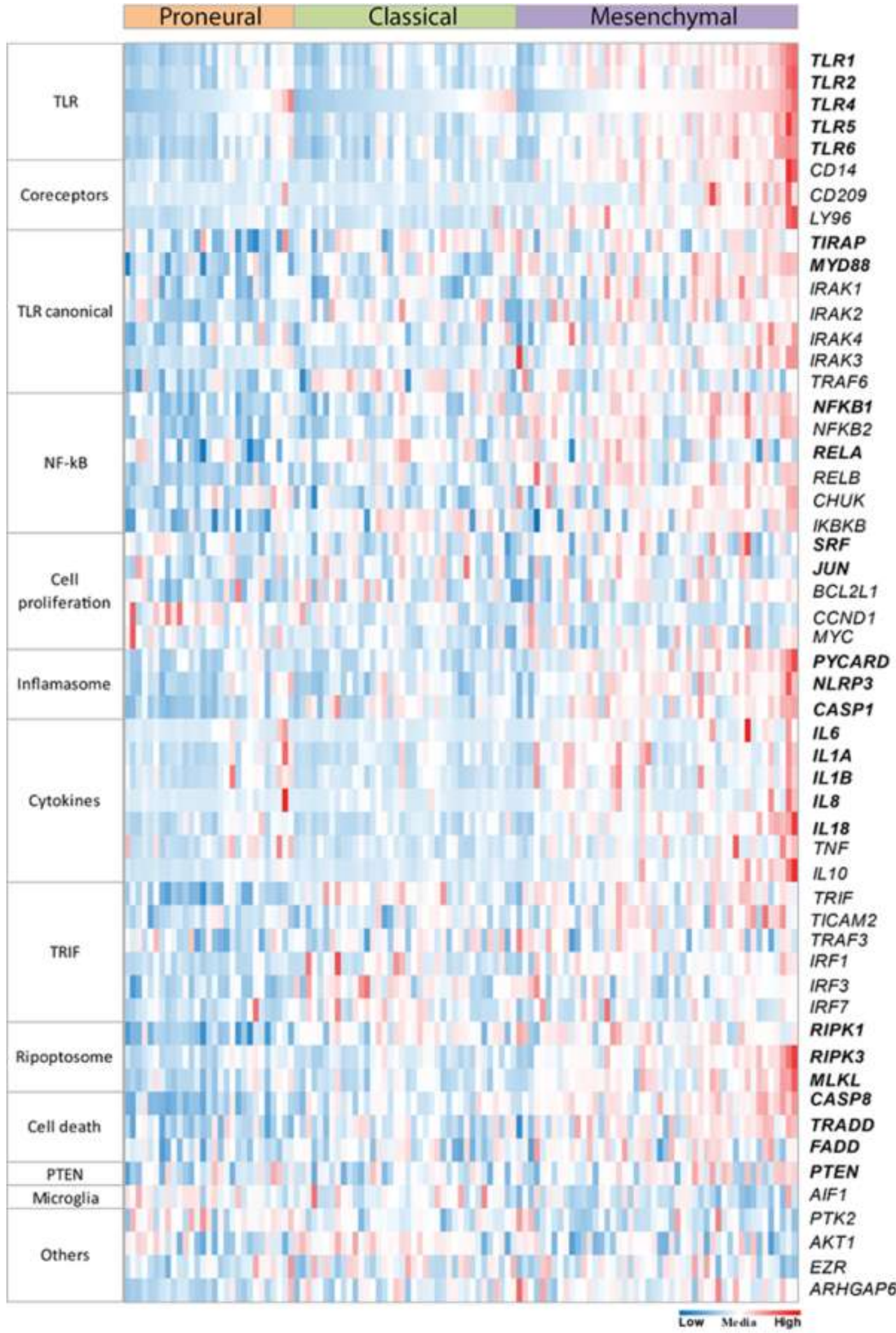

Figure 9. Heatmap with major genes of the TLR signaling pathways from the TCGA dataset. RPKM gene expression levels are normalized by z-scores, and comparatively up-regulated RNA expression values are presented in red and down-regulated values in blue. Mean values are in white. TLRs downstream signaling pathways: canonical, ripoptosome, and inflammasome 
pathways are activated in mesenchymal GBM subtype. Genes of unrelated pathways were added to show their randomic expression levels, including a microglia marker.

\subsection{TLR4 presence in human astrocytomas}

\subsubsection{TLR4 expression is the highest among the plasma membrane} TLRs in human astrocytomas and U87MG cell line

The TLR4 transcript expression was higher in AGII, AGIII and GBM compared to non-neoplastic brain tissue (NN)(Figure 10A). Particularly in GBM, a wide spread of TLR4 transcription level was observed, and the highest expression was demonstrated in mesenchymal subtype, both in our GBM cohort (Figure 10B) and in the TCGA RNASeq dataset, with statistical significance in the latter (Figure 10C).

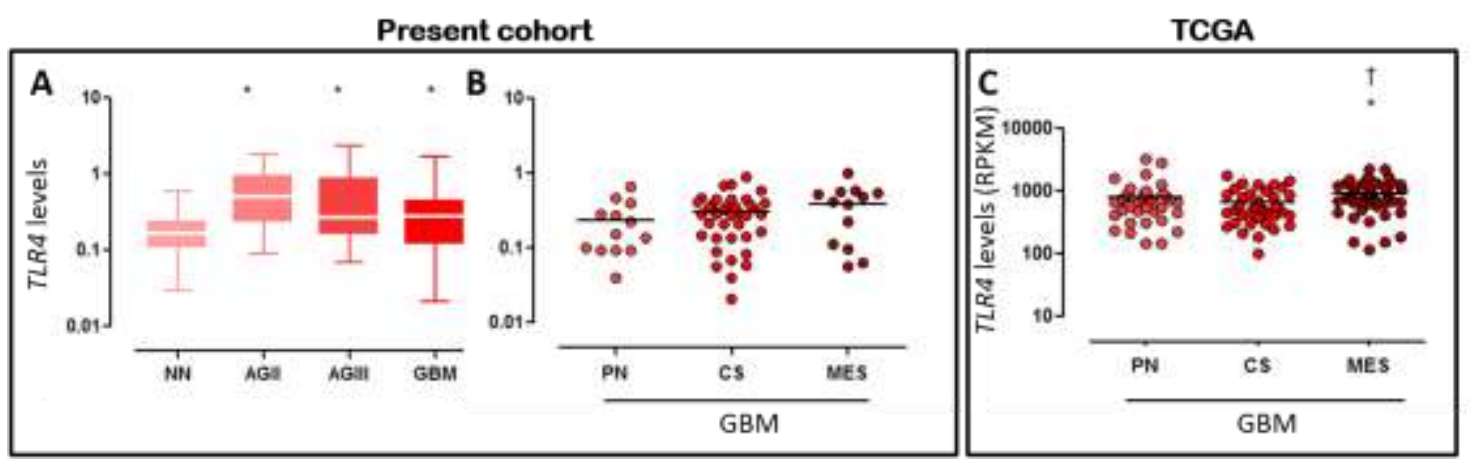

Figure 10. TLR4 expression. Data for the TLR4 mRNA levels observed by qRT-PCR indicating the importance of the target. (A) Comparison of TLR4 expression levels in the astrocytoma grades (AGII-GBM) and NN, in our cohort. (B) The expression levels of TLR4 in the GBM molecular subtypes: proneural (PN), classical (CS) and mesenchymal (MES) in our cohort, and in the TCGA RNAseq dataset (C). Mesenchymal subtype presented the highest expression level, being significant in the TCGA dataset compared to classical and proneural subtype $(p<0.05$ Kruskal-Wallis and Dunn test).

\subsection{The impact of inhibiting TLR4 in U87MG cells}

We analyze the viability by Presto blue of the U87MG cell line after TLR4 activation. Proliferative profile after 24 hours of stimulation was observed when stimulated with high concentration of LPS $(10 \mu \mathrm{g} / \mathrm{ml}$ and $100 \mu \mathrm{g} / \mathrm{ml})$ (Figure $11 \mathrm{~A}$ 
and B). The presence of p65 in the cell nuclei compartment after $12 \mathrm{hrs}$ of LPS stimulus was demonstrated by western blot (Figure 11C).

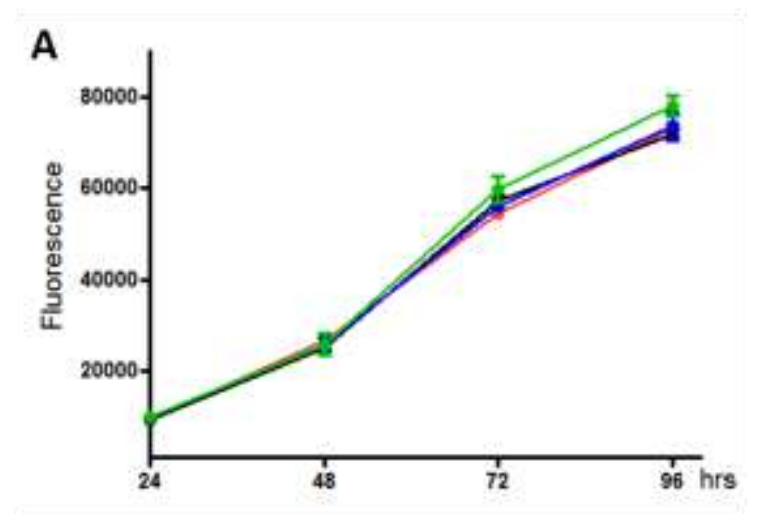

B

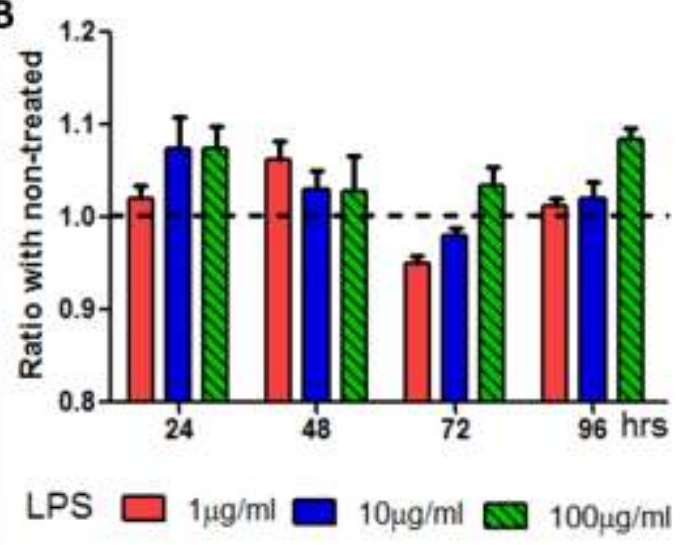

C $\begin{array}{lllll}\text { LPS } 10 \mu \mathrm{g} / \mathrm{ml} 2 \mathrm{hrs} & - & + & - & \mathrm{kDa}\end{array}$
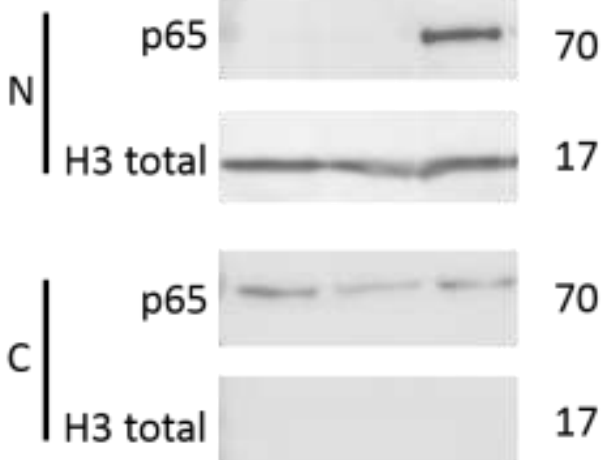

70 17

Figure 11. GBM U87MG cell line proliferative profile after LPS stimulation. (A) U87MG cells were treated with 3 different concentrations of LPS $(1 \mu \mathrm{g} / \mathrm{ml}$, $10 \mu \mathrm{g} / \mathrm{ml}$ and $100 \mu \mathrm{g} / \mathrm{ml}$ ) and cell proliferation was evaluated by Presto Blue reagent. The graphs represent levels of fluorescence at each time point and LPS concentration. (B) and the ratio with the non-treated cells. (C) Nuclear and cytoplasm protein extractions were performed after $2 \mathrm{hs}$ and $12 \mathrm{hs}$ of LPS treatment with $10 \mu \mathrm{g} / \mathrm{ml}$. The p65 and Histone H3 proteins were demonstrated in cytoplasm and nucleus compartments by western blot, and the presence of p65 in nuclei was detected after $12 \mathrm{hs}$ of LPS stimulus.

\subsubsection{TLR4 pathway pharmacological inhibition}

Chemical blockage of TLR4 signaling pathway was tested by VGX-1027 treatment which resulted in a decrease of U87MG cell line proliferation rate, after LPS stimulus (Figure 12). These findings corroborate the participation of the TLR4 in a signaling pathway leading to a proliferative phenotype of U87MG cells. 

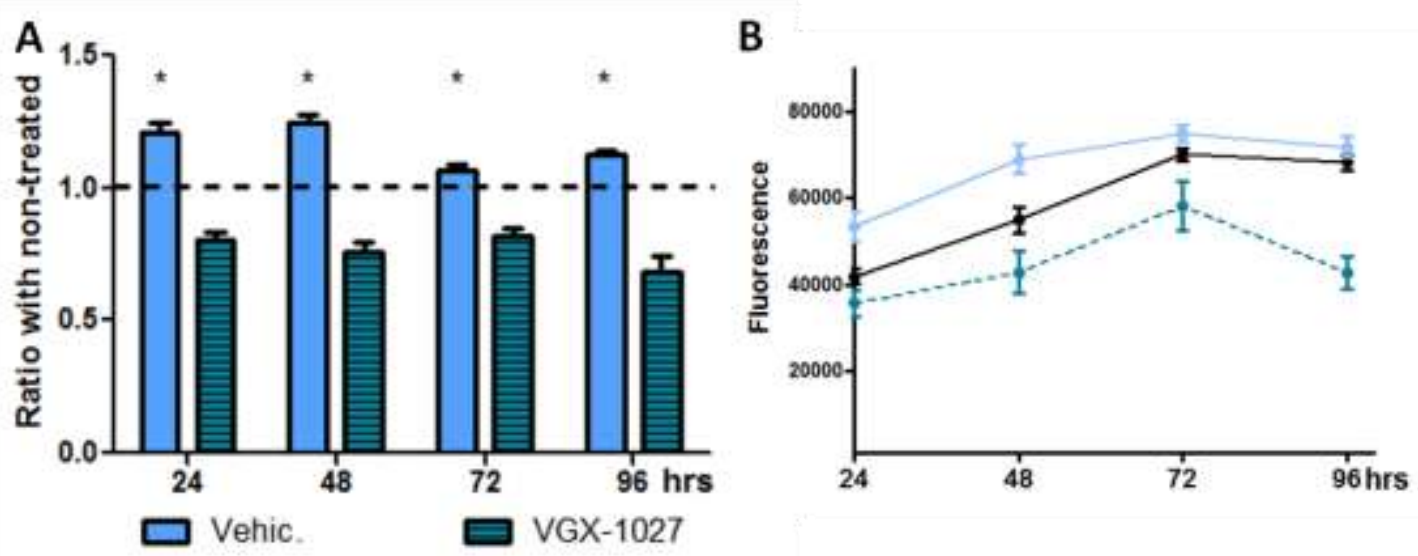

Figure 12. TLR4 pathway inhibitor. TLR4 signaling pathway inhibition by VGX-1027 $(1 \mu \mathrm{M})$ diluted in ethanol (vehicle). The treatment analysis was performed after 4 different time points by Presto Blue. To analyze TLR4 inhibition, U87MG were treated with LPS $(10 \mu \mathrm{g} / \mathrm{ml})$. The values were normalized by the U87MG non-treated cells, wherein ${ }^{*} p<0.05$ (Two-way ANOVAs and post hoc Bonferroni) and are present in relation to the non-treated cells (A) and the proliferation curve for each variable, the control (black), the cells treated only by the vehicle and LPS $(10 \mu \mathrm{g} / \mathrm{ml})$ (light blue) and the cells treated by the VGX-1027 and LPS (10 $\mathrm{g} / \mathrm{ml})$ (dark blue) (B).

\subsubsection{TLR4 in tumor and microglia cells crosstalk}

To analyze the distribution of TLR4 protein expression among specific cell compartments in GBM tumor, sequential GBM-TMA sections were stained for microglia IBA1 marker and TLR4. We highlighted different niches that were observed with distinct patterns of immunoreaction for both markers (Figure 13). Interestingly, microglia compartment showed increased in vascularized and necrotic areas with an activated profile. Furthermore, TLR4 was expressed in microglial cells on those areas. Phenotypically tumor cells showed increased TLR4 not only in cytoplasm but also in nuclei. However, the abundance of TLR4 protein expression varied further according to the density of microvessels, and to the proximity of necrotic area. Tumor areas with surveillant microglia phenotypes showed absent for TLR4 immunoreaction. 


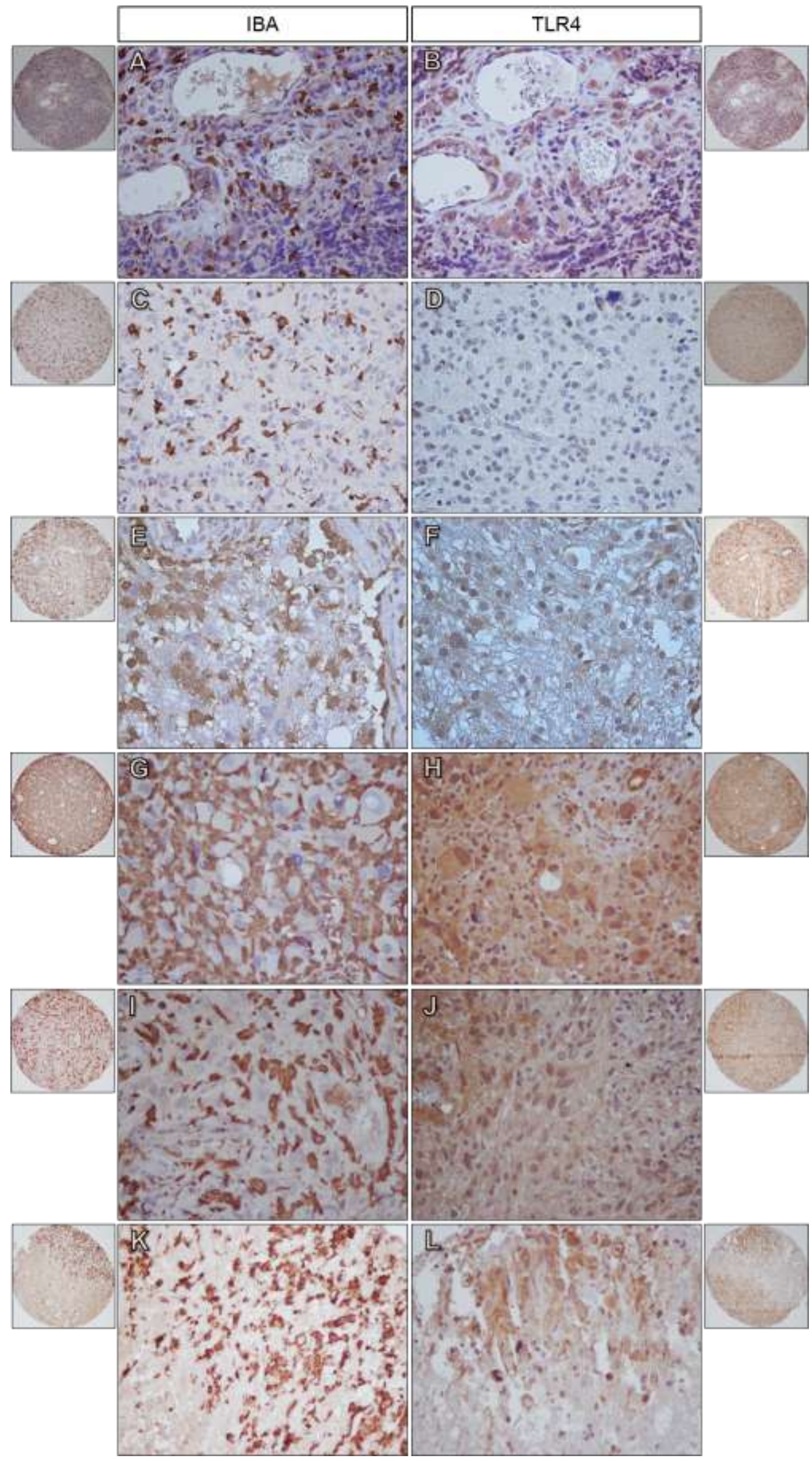


Figure 13. Immunohistochemistry of sequential TMA preparations of GBM cases for IBA1 microglia marker, and TLR4. A-B: positively IBA1 stained cells, microglia, were distributed surrounding vessels interspersed by TLR4 positive tumor cells. The small GBM cells in the bulk of tumor were negative for TLR4. C-D: quiescent microglia with narrow cytoplasmic ramifications were distributed randomly among tumor cells not immunoreacting for TLR4. E-F: another spot from an area of high vascular density of the same GBM case of C$D$ shows activated microglia with amoeboid morphology around the vessels and few slightly stained tumor cells for TLR4. G-H: GBM tumor cells completely surrounded by activated microglia, with intense positivity for TLR4. Tumor cell plasma membrane shows clear positivity for TLR4 as the endothelial cells. I-J: Activated microglia are distributed predominantly around vessels, and a gradient of positive staining for TLR4 is observed in tumor cells, with increase towards the center of vascularized tumor area. K-L: perinecrotic area of the same GBM case of I-J shows high density of microglia and intensely positive tumor cells for TLR4. 


\section{Discussion}

In the present study, higher expression levels of TLR1, TLR2, TLR4, $T L R 5$, and $T L R 6$ were demonstrated in human diffusely infiltrating astrocytomas (grades II to IV) in comparison to non-neoplastic brain tissue. Moreover, an associated expression of these receptors was observed in GBM cases, suggesting their role in tumor aggressiveness. The presence of TLR4 has been previously described in GBM, particularly in $\mathrm{CD}_{133^{+}}$tumor stem cells $(79,80)$, and also in GBM cell lineages A172, U87MG (41, 81, 82), and U251 (83). Such TLR4 positivity conferred a proliferative phenotype to these tumor cells $(79,83)$. Furthermore, the presence of TLR2 was also detected in murine GL261 glioma cell line, and the activation of this receptor leads to an invasive and migratory profile of the tumor cells (84). We further demonstrated herein the presence of TLR1, TLR2, TLR5, and TLR6 in U87MG and A172 cell lineages and in human GBM specimens, at gene and protein expression levels. TLR4 was the most expressed receptor in both cell lineages and tumor specimens. Interestingly, TLR4 and TLR5 positivity were detected in the tumor cell nuclei by immunofluorescence in cell lineages and by immunohistochemistry in tumor specimens. However, such observation needs confirmation in other cohorts before speculating their possible role in this localization. In spite of both cell lineages presenting somatic mutation profiles of mesenchymal molecular subtype of GBM, they present distinct expression profiles of these TLRs. U87MG cells showed higher expression of TLR1, TLR2, and TLR4 compared to A172, in contrast to lower expression of TLR5. Such heterogeneity of these TLRs expression distributions was also observed in human astrocytoma samples from our cohort and in the TCGA dataset, particularly among GBMs, where higher expression levels were detected in mesenchymal subtype. To analyze the impact of these differential TLRs expressions among the molecular subtypes of GBM, we built a heatmap with the expression levels of the genes involved in pathways related to TLRs from the TCGA dataset (Figure 9). Interestingly, this approach showed clearly the downstream activation of the 
canonical, ripoptosome, and inflammasome pathways, related to the up regulation of the TLRs, particularly in the mesenchymal subtype of GBM. The end targets of these pathways, including cytokines (IL1A/B,IL6,IL8,IL18) and genes related to cell proliferation (JUN, SRF), were up regulated, suggesting that the activation of these TLRs leads to tumor growth. In fact, activation of the TLR canonical pathway through TIRAP-MYD88 was related to NF-kB (RELA) up regulated expression levels and positive correlation with $J U N$, and $S R F$, transcription factors implicated in cellular proliferation. The role of NF-kB in tumor growth has been demonstrated in a mouse model of GBM (85) and in pulmonary tumor cells (86). Additionally, it has been reported that such a proliferative response may be time- and dose-dependent (87). Therefore, tumor inflammatory microenvironment may contribute to distinct NF-KB pulsationdetermining tumor cell behavior in each specific condition. The end targets of this pathway, IL-6, IL- $1 \alpha$ and IL-1 $\beta$, and IL-8 cytokines, presented increased expression in the mesenchymal subtype, and they have also been associated to tumor malignancy and tumor cell migration (60, 88-90). IL1B and IL 18 are also end targets of the inflammasome pathway, which were up regulated in the mesenchymal subtype. On the other hand, the increased expression of RIPK3 and $M L K L$ may suggest the up regulation of the ripoptosome pathway, and may allow the link with the presence of necrosis, one of the characteristics of GBM. In a rat glioma model, apoptosis was induced by activation of CASP8 and inhibition of RIPK1/RIPK3 complex (57, 91, 92).

The expression of CASP8 was increased in the mesenchymal subtype of GBM; however, increased apoptosis is not expected and, therefore, avoidance of apoptosis should be under additional modulation. Moreover, according to the present in silico analysis, the interferon type I response by TLR4 endocytosis was unlikely.

Another hypothesis for the proliferative profile and TLR signaling in GBM is the pathway involving PTEN, which has been shown to regulate TIRAP and TLR4 internalization $(93,94)$, in addition to its classic suppressor role in the PI3K-AKT-mTOR pathway (95). Loss of function of PTEN may occur by its deletion or phosphorylation $(65,96)$. Our previous analysis of PTEN status in our GBM cohort demonstrated $24.32 \%$ and $26.66 \%$ of PTEN deletion, and 
$59.45 \%$ and $66.66 \%$ of PTEN phosphorylation in classical and mesenchymal subtypes, respectively (Figure 14) $(77,96)$, demonstrating more prevalent PTEN loss of function in the classical subtype. These PTEN alterations may lead to a decreased inhibition over TIRAP (Figure 15) and consequent TLR canonical pathway activation. In B cells, the absence of PTEN showed an increased in NF-KB activity after TLR4 stimulation (97). Additionally NF-KB negatively regulates PTEN $(98,99)$. Accordingly, in the classical subtype, loss of PTEN may also be implicated in tumor cell proliferation through TLR canonical activation (Figure 15). Actually, our analysis of the TCGA dataset showed significant correlation between TIRAP and PTEN expression levels among the classical GBM subtype ( $r=0.330, p<0.05$, Spearman-rho test). Interestingly, a negative correlation was found between them in the proneural subtype $(r=-0.382, p<0.05)$, which presents better prognosis among the three analyzed GBM subtypes.

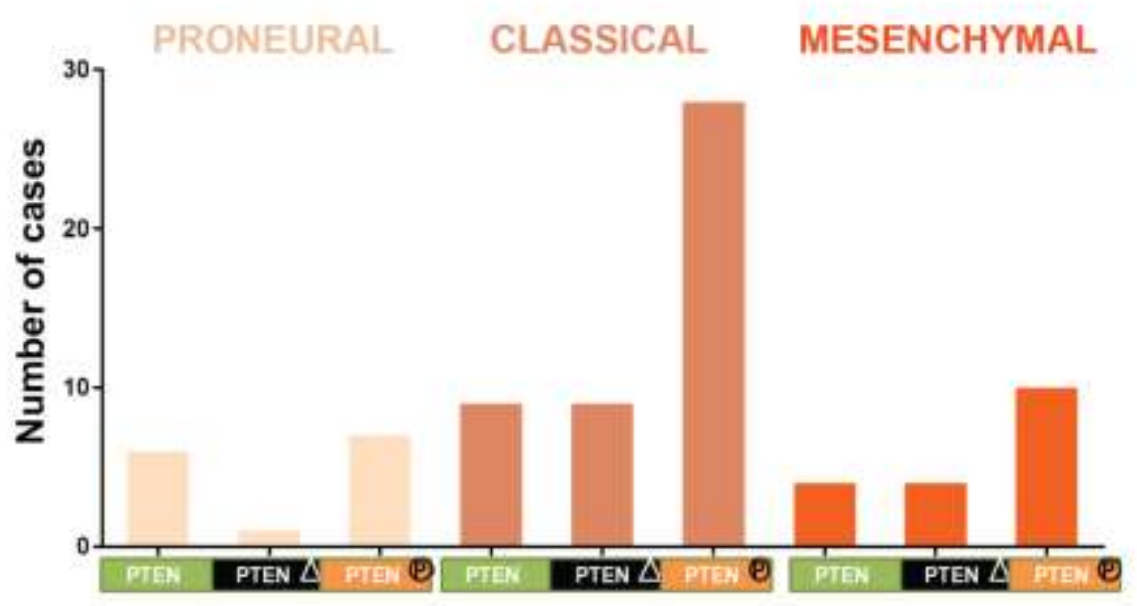

Figure 14. PTEN. The GBM cohort from our lab was previously analyzed for PTEN mutational and phosphorylation status. The number of cases for each status of PTEN and GBM subtype is presented. In green is the amount of cases presenting wild-type PTEN, in black the deleted PTEN, and in orange the Y240phosphorylated PTEN. 


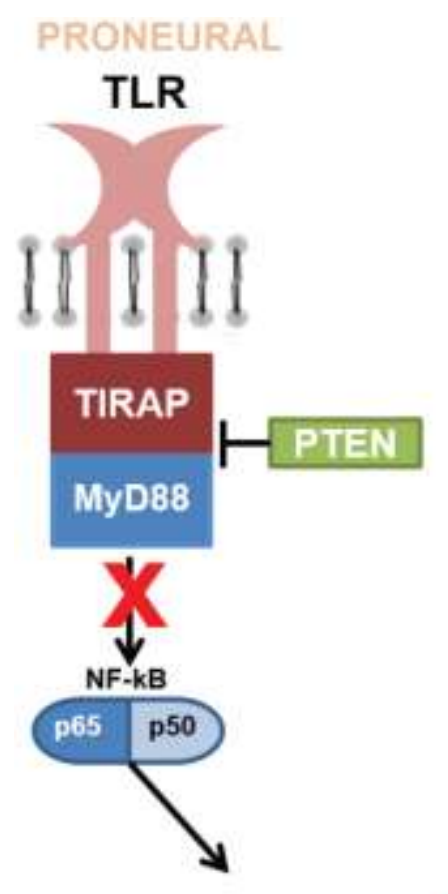

CLASSICAL

TLR

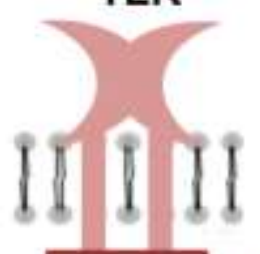

TIRAP

MyD88
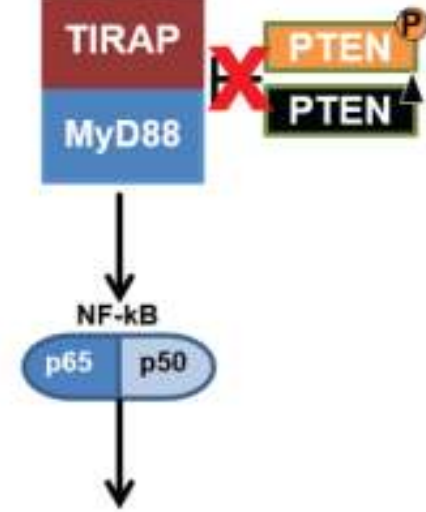

PTEN

\section{cell proliferation}

MESENCHYMAL

TLR
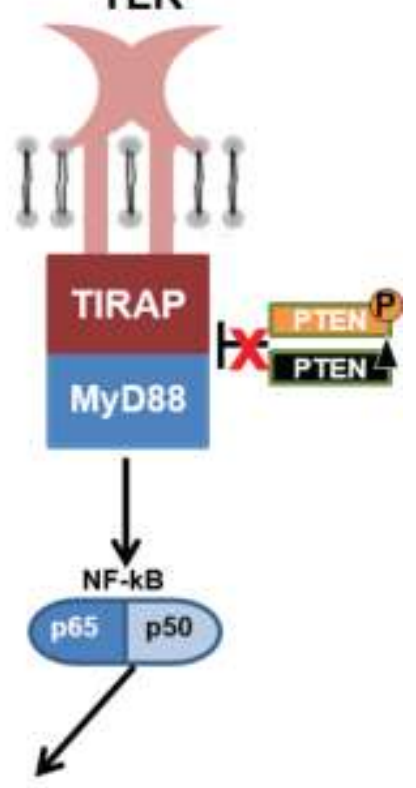

Figure 15. Schematic proposition of the TLR canonical signaling pathway through TIRAP by PTEN regulation. PTEN alterations may lead to up regulation of TLR signaling pathway and may increase tumor cell proliferation. Loss of PTEN repressor role by its deletion or phosphorylation, as may occur more frequently in classical subtype, may activate downstream TLR canonical pathway through the decreased inhibition over TIRAP. This pathway through TIRAP-PTEN may not be the major mechanism in mesenchymal subtype, and the integrity of PTEN may inhibit TIRAP and then not activate this pathway in proneural subtype.

To further understand the TLRs role in tumor cells we chose to perform functional analysis targeting TLR4, whom expression level was higher compared to the others TLRs and also higher in the U87MG GBM tumor cell line. This cell line presents mesenchymal molecular subtype pattern, harboring Neurofibromin 1 (NF1) mutation (78). We designed functional assays employing LPS, a known agonist for TLR4 that activates pro-inflammatory pathways, in wild type U87MG cells and inhibited by a TLR4 blocking pharmacological compound (VGX-1027). Interestingly, no proliferative response was observed in the wild-type U87MG cell treated with LPS, and a reasonable explanation for such observation was that the pro-proliferative signaling pathways might be already saturated in this mesenchymal subtype GBM cell line, and an activation of additional proproliferative pathway resulted in any phenotypic change. In fact, although no 
significant change was detected, the NF-kB nuclear translocation was demonstrated after 12 hours of LPS stimulation. The observed late phase of NF-kB activation after 12 hours from the stimulation suggests that the activation did not occur through a canonical pathway, NF-kB translocation to the nucleus is described early phases of the activation, ceasing after 100 minutes (87). The current finding might indicate a nomn-canonical TRIF dependent pathway activation (100)

The proliferative response of U87MG cells has been previously associated to NF-kB activation (101, 102). Additionally, pro-inflammatory response of increased proliferation after TLR4 stimulation with cytokines production has been reported in tumor cells of different origins as hepatocarcinoma, esophagus, ovarian and melanoma after TLR4 stimulation (103-107). And, in vivo models of different tumors harboring up regulated TLR4 have shown increased tumor cell survival and the receptor inhibition has resulted in smaller tumors and prolonged animal survival (108). TLR4 has also been described related to drug resistance and metastasis (109). In fact, in the present study, the downregulation of TLR4 signaling pathway by chemical blockade with VGX-1027, resulted in a decrease of U87MG cell proliferation. VGX-1027 administration has been shown to decrease IL-1 $\beta$ and TNF secretion and to downregulate NF-kB and p38 MAP kinase (76). The VGX-1027 has been implicated in the attenuation LPS effect. Also, in vitro, ex vivo and in vivo models, the VGX-1027 has downregulated inflammation, mainly of macrophages (110). In two clinical studies, the VGX-1027 downregulated inflammation in rheumatoid disease (111).

However, TLR4 may also activate a pro-apoptotic pathway by CASP8 under inhibitory modulation of c-FLIP (CASP8 and FADD like apoptosis regulator - CFLAR) (112). The protein c-FLIP promotes cell survival preventing either apoptotic signaling by CASP8 or necroptotic signaling by RIPK1/RIPK3 (113).

The final response due to TLR4 activation will depend of tumor microenvironment, which is dynamically changing. TLR4 was present in tumor cells, but also in brain innate inflammatory cells, as microglia (Figure 15), and therefore both cells are theoretically prone to DAMPs, such as heat-shock 
proteins (HSP), and extra-cellular matrix (ECM) molecules (43). GBM tumor cell migration as a process dependent of EGFR activated by TLR4 bound to HSP90, a DAMP signal, has been previously reported $(83,109,114)$. Therefore, TLR4 activation has been associated to tumor promotion $(115,116)$. However, the complete range of PAMPs and DAMPs related to TLR4 as the precise mechanism of their activation pathways are still under investigation $(117,118)$.

Several evidences indicate the pro-tumorigenic effect of microglia in gliomas $(66,119-123)$. In the present study, we identified microglia expressing TLR4 protein around vessels and hypoxic areas. We speculated, based on these findings that TLR4 may lead GBM microglia to change to a protumorigenic profile. Indeed, tumor microglia expressing TLR4 may be prone to tumor released activating factors. Among these factors, IL-6 secreted by the tumor cell may activate tumor microglia to this profile through TLR4. And, in response, microglia may produce IL-10 a cytokine capable to abrogate immune response $(124,125)$. Moreover, microglia also expresses TLR2, which can also be activated by DAMPs. TLR2 is also associated to glioma-immune system evasion and production of tumor growth factors (126, 127). Additionally, microglia has been described around vessels and hypoxic areas (128). Necrotic cells may stimulate cytokine production, angiogenic factors, as vascular endothelial growth factor (VEGF) (129-132), and ECM modulators (133) by tumor cells and microglia (102), a process that can be mediated by TLRs. Angiogenesis and pro-inflammatory response stimulation by necrotic cells are considered cancer hallmarks (1).

Thus, further studies of the TLR responses from each tumor compartment, which includes inflammatory cells in addition to tumor cells, will be essential to better understand the tumor behavior and to develop new strategies to try to control its aggressiveness. 


\section{Conclusions}

1) Increased cell membrane TLR1, TLR2, TLR4, TLR5, and TLR6 expressions were demonstrated in astrocytomas compared to nonneoplastic brain tissue, mostly in GBM group, and particularly in the mesenchymal subtype.

2) In silico exploration of the putative activation pathways by these up regulated TLRs, the canonical and inflammasome pathways in the mesenchymal subtype and the PTEN-TIRAP signaling in the classical subtype were demonstrated and their possible contribution to tumor growth.

3) According to the TCGA dataset the microglia compartment based on AIF1 expression level did not parallel the TLRs up regulated expressions in mesenchymal subtype, suggesting that the tumor cells themselves may contribute to the increased expression of these receptors.

4) TLR4 activation by LPS stimulation lead to NF-kB late translocation to nucleus in U87MG cell and, the TLR4 chemical blockage resulted in a U87MG cell proliferation decrease.

5) Microglia also present TLR4 expression and the final phenotype due to this receptor activation may be determined by the tumor microenvironment dynamics. 


\section{References}

1. Hanahan D, Weinberg Robert A. Hallmarks of Cancer: The Next Generation. Cell. 2011;144(5):646-74.

2. Neher JJ, Neniskyte U, Zhao J-W, Bal-Price A, Tolkovsky AM, Brown GC. Inhibition of Microglial Phagocytosis Is Sufficient To Prevent Inflammatory Neuronal Death. The Journal of Immunology. 2011;186(8):4973.

3. Witting A, Müller P, Herrmann A, Kettenmann H, Nolte C. Phagocytic Clearance of Apoptotic Neurons by Microglia/Brain Macrophages In Vitro. Journal of Neurochemistry. 2002;75(3):1060-70.

4. Appel JR, Ye S, Tang F, Sun D, Zhang H, Mei L, et al. Increased Microglial Activity, Impaired Adult Hippocampal Neurogenesis, and Depressive-like Behavior in Microglial VPS35-Depleted Mice. J Neurosci. 2018;38(26):5949-68.

5. Luo C, Ikegaya Y, Koyama R. Microglia and neurogenesis in the epileptic dentate gyrus. Neurogenesis (Austin). 2016;3(1):e1235525.

6. Wlodarczyk A, Holtman IR, Krueger M, Yogev N, Bruttger J, Khorooshi R, et al. A novel microglial subset plays a key role in myelinogenesis in developing brain. Embo j. 2017;36(22):3292-308.

7. L'Episcopo F, Tirolo C, Serapide MF, Caniglia S, Testa N, Leggio L, et al. Microglia Polarization, Gene-Environment Interactions and Wnt/beta-Catenin Signaling: Emerging Roles of GliaNeuron and Glia-Stem/Neuroprogenitor Crosstalk for Dopaminergic Neurorestoration in Aged Parkinsonian Brain. Front Aging Neurosci. 2018;10:12.

8. Zhang J, Xie X, Tang M, Zhang B, Zhao Q, Han Y, et al. Salvianolic acid B promotes microglial M2-polarization and rescues neurogenesis in stress-exposed mice. Brain Behav Immun. 2017;66:111-24.

9. Cunningham CL, Martínez-Cerdeño V, Noctor SC. Microglia Regulate the Number of Neural Precursor Cells in the Developing Cerebral Cortex. The Journal of Neuroscience. 2013;33(10):4216.

10. Brown GC, Neher JJ. Microglial phagocytosis of live neurons. Nat Rev Neurosci. 2014;15(4):209-16.

11. Yu Y, Li J, Zhou H, Xiong Y, Wen Y, Li H. Functional importance of the TGF-beta1/Smad3 signaling pathway in oxygen-glucose-deprived (OGD) microglia and rats with cerebral ischemia. Int $\mathbf{J}$ Biol Macromol. 2018;116:537-44.

12. Turkowski K, Brandenburg S, Mueller A, Kremenetskaia I, Bungert AD, Blank A, et al. VEGF as a modulator of the innate immune response in glioblastoma. Glia. 2018;66(1):161-74.

13. Brandenburg S, Muller A, Turkowski K, Radev YT, Rot S, Schmidt C, et al. Resident microglia rather than peripheral macrophages promote vascularization in brain tumors and are source of alternative pro-angiogenic factors. Acta Neuropathol. 2016;131(3):365-78.

14. Yin J, Xu WQ, Ye MX, Zhang Y, Wang HY, Zhang J, et al. Up-regulated basigin-2 in microglia induced by hypoxia promotes retinal angiogenesis. J Cell Mol Med. 2017;21(12):3467-80.

15. Martiskainen H, Paldanius KMA, Natunen T, Takalo M, Marttinen M, Leskela S, et al. DHCR24 exerts neuroprotection upon inflammation-induced neuronal death. J Neuroinflammation. 2017;14(1):215. 16. Larochelle A, Bellavance MA, Rivest S. Role of adaptor protein MyD88 in TLR-mediated preconditioning and neuroprotection after acute excitotoxicity. Brain Behav Immun. 2015;46:221-31.

17. Zemlyak I, Brooke S, Sapolsky R. Estrogenic protection against gp120 neurotoxicity: role of microglia. Brain Res. 2005;1046(1-2):130-6.

18. Miao J, Ding M, Zhang A, Xiao Z, Qi W, Luo N, et al. Pleiotrophin promotes microglia proliferation and secretion of neurotrophic factors by activating extracellular signal-regulated kinase $1 / 2$ pathway. Neuroscience Research. 2012;74(3):269-76.

19. Gomes C, Ferreira R, George J, Sanches R, Rodrigues DI, Goncalves N, et al. Activation of microglial cells triggers a release of brain-derived neurotrophic factor (BDNF) inducing their proliferation in an adenosine A2A receptor-dependent manner: A2A receptor blockade prevents BDNF release and proliferation of microglia. J Neuroinflammation. 2013;10:16.

20. Mosser CA, Baptista S, Arnoux I, Audinat E. Microglia in CNS development: Shaping the brain for the future. Prog Neurobiol. 2017;149-150:1-20.

21. Kierdorf K, Prinz M. Microglia in steady state. J Clin Invest. 2017;127(9):3201-9. 
22. Karperien A, Ahammer H, Jelinek H. Quantitating the subtleties of microglial morphology with fractal analysis. Frontiers in Cellular Neuroscience. 2013;7:3.

23. Casano Alessandra M, Peri F. Microglia: Multitasking Specialists of the Brain. Developmental Cell. 2015;32(4):469-77.

24. Allen NJ, Lyons DA. Glia as architects of central nervous system formation and function. Science. 2018;362(6411):181-5.

25. Neniskyte U, Gross CT. Errant gardeners: glial-cell-dependent synaptic pruning and neurodevelopmental disorders. Nature Reviews Neuroscience. 2017;18:658.

26. Hickman SE, Kingery ND, Ohsumi T, Borowsky M, Wang L-c, Means TK, et al. The Microglial Sensome Revealed by Direct RNA Sequencing. Nature neuroscience. 2013;16(12):1896-905.

27. Sierra A, de Castro F, Del Rio-Hortega J, Rafael Iglesias-Rozas J, Garrosa M, Kettenmann H. The "Big-Bang" for modern glial biology: Translation and comments on Pio del Rio-Hortega 1919 series of papers on microglia. Glia. 2016;64(11):1801-40.

28. Brawek B, Schwendele B, Riester K, Kohsaka S, Lerdkrai C, Liang Y, et al. Impairment of in vivo calcium signaling in amyloid plaque-associated microglia. Acta Neuropathol. 2014;127(4):495-505.

29. Hanisch UK. Functional diversity of microglia - how heterogeneous are they to begin with? Front Cell Neurosci. 2013;7:65.

30. Mathys H, Adaikkan C, Gao F, Young JZ, Manet E, Hemberg M, et al. Temporal Tracking of Microglia Activation in Neurodegeneration at Single-Cell Resolution. Cell Rep. 2017;21(2):366-80.

31. Fuger P, Hefendehl JK, Veeraraghavalu K, Wendeln AC, Schlosser C, Obermuller U, et al. Microglia turnover with aging and in an Alzheimer's model via long-term in vivo single-cell imaging. Nat Neurosci. 2017;20(10):1371-6.

32. Galatro TF, Holtman IR, Lerario AM, Vainchtein ID, Brouwer N, Sola PR, et al. Transcriptomic analysis of purified human cortical microglia reveals age-associated changes. Nature Neuroscience. 2017;20:1162.

33. Olah M, Patrick E, Villani A-C, Xu J, White CC, Ryan KJ, et al. A transcriptomic atlas of aged human microglia. Nature Communications. 2018;9(1):539.

34. Roesch S, Rapp C, Dettling S, Herold-Mende C. When Immune Cells Turn Bad-TumorAssociated Microglia/Macrophages in Glioma. Int J Mol Sci. 2018;19(2).

35. Bowman RL, Klemm F, Akkari L, Pyonteck SM, Sevenich L, Quail DF, et al. Macrophage Ontogeny Underlies Differences in Tumor-Specific Education in Brain Malignancies. Cell Rep. 2016;17(9):2445-59.

36. Quail DF, Joyce JA. The Microenvironmental Landscape of Brain Tumors. Cancer Cell. 2017;31(3):326-41.

37. Matias D, Balca-Silva J, da Graca GC, Wanjiru CM, Macharia LW, Nascimento CP, et al. Microglia/Astrocytes-Glioblastoma Crosstalk: Crucial Molecular Mechanisms and Microenvironmental Factors. Front Cell Neurosci. 2018;12:235.

38. Sevenich L. Brain-Resident Microglia and Blood-Borne Macrophages Orchestrate Central Nervous System Inflammation in Neurodegenerative Disorders and Brain Cancer. Front Immunol. 2018;9:697.

39. Walentynowicz KA, Ochocka N, Pasierbinska M, Wojnicki K, Stepniak K, Mieczkowski J, et al. In Search for Reliable Markers of Glioma-Induced Polarization of Microglia. Front Immunol. 2018;9:1329.

40. Kawai T, Akira S. The role of pattern-recognition receptors in innate immunity: update on Tolllike receptors. Nature Immunology. 2010;11(5):373-84.

41. Rakoff-Nahoum S, Medzhitov R. Toll-like receptors and cancer. Nat Rev Cancer. 2009;9(1):57-

63.

42. Pradere JP, Dapito DH, Schwabe RF. The Yin and Yang of Toll-like receptors in cancer. Oncogene. 2014;33(27):3485-95.

43. Piccinini AM, Midwood KS. DAMPening Inflammation by Modulating TLR Signalling. Mediators of Inflammation. 2010;2010:672395.

44. Botos I, Segal DM, Davies DR. The Structural Biology of Toll-like Receptors. Structure. 2011;19(4):447-59.

45. Ben-Neriah Y, Karin M. Inflammation meets cancer, with NF-[kappa]B as the matchmaker. Nat Immunol. 2011;12(8):715-23.

46. Hayden MS, Ghosh S. Signaling to NF-kappaB. Genes Dev. 2004;18(18):2195-224.

47. Karin M, Ben-Neriah Y. Phosphorylation meets ubiquitination: the control of NF-[kappa]B 
activity. Annu Rev Immunol. 2000;18:621-63.

48. Qin Z-h, Tao L-y, Chen X. Dual roles of NF-[kappa]B in cell survival and implications of NF[kappa]B inhibitors in neuroprotective therapy. Acta Pharmacol Sin. 2007;28(12):1859-72.

49. David A, Arnaud N, Fradet M, Lascaux H, Ouk-Martin C, Gachard N, et al. c-Myc dysregulation is a co-transforming event for nuclear factor-kappaB activated B cells. Haematologica. 2017;102(5):88394.

50. Lin CY, Lovén J, Rahl PB, Paranal RM, Burge CB, Bradner JE, et al. Transcriptional Amplification in Tumor Cells with Elevated c-Myc. Cell. 2012;151(1):56-67.

51. Mechta-Grigoriou F, Gerald D, Yaniv M. The mammalian Jun proteins: redundancy and specificity. Oncogene. 2001;20(19):2378-89.

52. Schratt G, Weinhold B, Lundberg AS, Schuck S, Berger J, Schwarz H, et al. Serum response factor is required for immediate-early gene activation yet is dispensable for proliferation of embryonic stem cells. Mol Cell Biol. 2001;21(8):2933-43.

53. Chaturvedi MM, Sung B, Yadav VR, Kannappan R, Aggarwal BB. NF-kappaB addiction and its role in cancer: 'one size does not fit all'. Oncogene. 2011;30(14):1615-30.

54. Farhat K, Riekenberg S, Heine H, Debarry J, Lang R, Mages J, et al. Heterodimerization of TLR2 with TLR1 or TLR6 expands the ligand spectrum but does not lead to differential signaling. Journal of Leukocyte Biology. 2008;83(3):692-701.

55. Tan Y, Zanoni I, Cullen Thomas W, Goodman Andrew L, Kagan Jonathan C. Mechanisms of Toll-like Receptor 4 Endocytosis Reveal a Common Immune-Evasion Strategy Used by Pathogenic and Commensal Bacteria. Immunity. 2015;43(5):909-22.

56. Kaiser WJ, Sridharan H, Huang C, Mandal P, Upton JW, Gough PJ, et al. Toll-like Receptor 3mediated Necrosis via TRIF, RIP3, and MLKL. The Journal of Biological Chemistry. 2013;288(43):31268-79.

57. Newton K, Dugger DL, Maltzman A, Greve JM, Hedehus M, Martin-McNulty B, et al. RIPK3 deficiency or catalytically inactive RIPK1 provides greater benefit than MLKL deficiency in mouse models of inflammation and tissue injury. Cell Death Differ. 2016;23(9):1565-76.

58. Najjar M, Saleh D, Zelic M, Nogusa S, Shah S, Tai A, et al. RIPK1 and RIPK3 Kinases Promote Cell-Death-Independent Inflammation by Toll-like Receptor 4. Immunity.45(1):46-59.

59. Guo H, Callaway JB, Ting JPY. Inflammasomes: mechanism of action, role in disease, and therapeutics. Nat Med. 2015;21(7):677-87.

60. Guo B, Fu S, Zhang J, Liu B, Li Z. Targeting inflammasome/IL-1 pathways for cancer immunotherapy. Sci Rep. 2016;6:36107.

61. Louis DN, Ohgaki H, Wiestler OD, Cavenee WK, Burger PC, Jouvet A, et al. The 2007 WHO classification of tumours of the central nervous system (vol 114, pg 97, 2007). Acta Neuropathologica. 2007;114(5):547-.

62. Stupp R, Mason WP, van den Beuf MJ. Radiotherapy plus concomitant and adjuvant temozolomide for newly diagnosed glioblastoma (vol 352, pg 19, 2005). Annals of Oncology. 2005;16(6):949-.

63. Phillips HS, Kharbanda S, Chen R, Forrest WF, Soriano RH, Wu TD, et al. Molecular subclasses of high-grade glioma predict prognosis, delineate a pattern of disease progression, and resemble stages in neurogenesis. Cancer Cell. 2006;9(3):157-73.

64. Colman H, Zhang L, Sulman EP, McDonald JM, Shooshtari NL, Rivera A, et al. A multigene predictor of outcome in glioblastoma. Neuro Oncol. 2010;12(1):49-57.

65. Verhaak RG, Hoadley KA, Purdom E, Wang V, Qi Y, Wilkerson MD, et al. Integrated genomic analysis identifies clinically relevant subtypes of glioblastoma characterized by abnormalities in PDGFRA, IDH1, EGFR, and NF1. Cancer Cell. 2010;17(1):98-110.

66. Wang Q, Hu B, Hu X, Kim H, Squatrito M, Scarpace L, et al. Tumor Evolution of GliomaIntrinsic Gene Expression Subtypes Associates with Immunological Changes in the Microenvironment. Cancer Cell.32(1):42-56.e6.

67. Louis DN, Perry A, Reifenberger G, von Deimling A, Figarella-Branger D, Cavenee WK, et al. The 2016 World Health Organization Classification of Tumors of the Central Nervous System: a summary. Acta Neuropathol. 2016;131(6):803-20.

68. Galatro TFdA, Uno M, Oba-Shinjo SM, Almeida AN, Teixeira MJ, Rosemberg S, et al. Differential Expression of ID4 and Its Association with TP53 Mutation, SOX2, SOX4 and OCT-4 Expression Levels. PLOS ONE. 2013;8(4):e61605.

69. da Silva R, Uno M, Marie SKN, Oba-Shinjo SM. LOX Expression and Functional Analysis in 
Astrocytomas and Impact of IDH1 Mutation. PLOS ONE. 2015;10(3):e0119781.

70. Marie SKN, Okamoto OK, Uno M, Hasegawa APG, Oba-Shinjo SM, Cohen T, et al. Maternal embryonic leucine zipper kinase transcript abundance correlates with malignancy grade in human astrocytomas. International Journal of Cancer. 2008;122(4):807-15.

71. Oba-Shinjo SM, Bengtson MH, Winnischofer SMB, Colin C, Vedoy CG, de Mendonca Z, et al. Identification of novel differentially expressed genes in human astrocytomas by cDNA representational difference analysis. Molecular Brain Research. 2005;140(1-2):25-33.

72. Valente V, Teixeira SA, Neder L, Okamoto OK, Oba-Shinjo SM, Marie SKN, et al. Selection of suitable housekeeping genes for expression analysis in glioblastoma using quantitative RT-PCR. Bmc Molecular Biology. 2009;10:11.

73. Schindelin J, Arganda-Carreras I, Frise E, Kaynig V, Longair M, Pietzsch T, et al. Fiji: an opensource platform for biological-image analysis. Nat Methods. 2012;9(7):676-82.

74. Clara Carlos A, Marie Suely KN, Almeida José Reynaldo W, Wakamatsu A, Oba-Shinjo Sueli M, Uno M, et al. Angiogenesis and expression of PDGF-C, VEGF, CD105 and HIF-1 $\alpha$ in human glioblastoma. Neuropathology. 2014;34(4):343-52.

75. Bohannon JK, Hernandez A, Enkhbaatar P, Adams WL, Sherwood ER. The Immunobiology of TLR4 Agonists: From Endotoxin Tolerance to Immunoadjuvants. Shock (Augusta, Ga). 2013;40(6):451 62.

76. Fagone P, Muthumani K, Mangano K, Magro G, Meroni PL, Kim JJ, et al. VGX-1027 modulates genes involved in lipopolysaccharide-induced Toll-like receptor 4 activation and in a murine model of systemic lupus erythematosus. Immunology. 2014;142(4):594-602.

77. Galatro TF, Sola P, Moretti IF, Miura FK, Oba-Shinjo S, Marie SK, et al. Correlation between molecular features and genetic subtypes of Glioblastoma: critical analysis in 109 cases. MedicalExpress. 2017(Oct):M170505.

78. Forbes SA, Beare D, Gunasekaran P, Leung K, Bindal N, Boutselakis H, et al. COSMIC: exploring the world's knowledge of somatic mutations in human cancer. Nucleic Acids Research. 2015;43(D1):D805-D11.

79. Che F, Yin J, Quan Y, Xie X, Heng X, Du Y, et al. TLR4 interaction with LPS in glioma CD133+ cancer stem cells induces cell proliferation, resistance to chemotherapy and evasion from cytotoxic T lymphocyte-induced cytolysis. Oncotarget. 2017;8(32):53495-507.

80. Brescia P, Ortensi B, Fornasari L, Levi D, Broggi G, Pelicci G. CD133 is essential for glioblastoma stem cell maintenance. Stem Cells. 2013;31(5):857-69.

81. Gupta P, Ghosh S, Nagarajan A, Mehta VS, Sen E. $\beta$-defensin-3 negatively regulates TLR4HMGB1 axis mediated HLA-G expression in IL-1 $\beta$ treated glioma cells. Cellular Signalling. 2013;25(3):682-9.

82. Sarrazy V, Vedrenne N, Billet F, Bordeau N, Lepreux S, Vital A, et al. TLR4 signal transduction pathways neutralize the effect of Fas signals on glioblastoma cell proliferation and migration. Cancer Lett. 2011;311(2):195-202.

83. Thuringer D, Hammann A, Benikhlef N, Fourmaux E, Bouchot A, Wettstein G, et al. Transactivation of the epidermal growth factor receptor by heat shock protein 90 via Toll-like receptor 4 contributes to the migration of glioblastoma cells. J Biol Chem. 2011;286(5):3418-28.

84. Wang F, Zhang P, Yang L, Yu X, Ye X, Yang J, et al. Activation of toll-like receptor 2 promotes invasion by upregulating MMPs in glioma stem cells. American Journal of Translational Research. 2015;7(3):607-15.

85. Friedmann-Morvinski D, Narasimamurthy R, Xia Y, Myskiw C, Soda Y, Verma IM. Targeting NF-кB in glioblastoma: A therapeutic approach. Sci Adv. 22016.

86. Bivona TG, Hieronymus H, Parker J, Chang K, Taron M, Rosell R, et al. FAS and NF-kappaB signalling modulate dependence of lung cancers on mutant EGFR. Nature. 2011;471(7339):523-6.

87. Turner DA, Paszek P, Woodcock DJ, Nelson DE, Horton CA, Wang Y, et al. Physiological levels of TNFalpha stimulation induce stochastic dynamics of NF-kappaB responses in single living cells. J Cell Sci. 2010;123(Pt 16):2834-43.

88. Fisher DT, Appenheimer MM, Evans SS. The two faces of IL-6 in the tumor microenvironment. Semin Immunol. 2014;26(1):38-47.

89. Ahn S-H, Park H, Ahn Y-H, Kim S, Cho M-S, Kang JL, et al. Necrotic cells influence migration and invasion of glioblastoma via NF- $\mathrm{B} / \mathrm{AP}-1-$ mediated IL-8 regulation. Scientific Reports. 2016;6:24552.

90. Lewis $\mathrm{AM}$, Varghese $\mathrm{S}, \mathrm{Xu} \mathrm{H}$, Alexander HR. Interleukin-1 and cancer progression: the 
emerging role of interleukin-1 receptor antagonist as a novel therapeutic agent in cancer treatment. Journal of Translational Medicine. 2006;4:48-.

91. Raza SM, Lang FF, Aggarwal BB, Fuller GN, Wildrick DM, Sawaya R. Necrosis and glioblastoma: a friend or a foe? A review and a hypothesis. Neurosurgery. 2002;51(1):2-12; discussion -3. 92. Das A, McDonald DG, Dixon-Mah YN, Jacqmin DJ, Samant VN, Vandergrift WA, et al. RIP1 and RIP3 complex regulates radiation-induced programmed necrosis in glioblastoma. Tumor Biology. 2016;37(6):7525-34.

93. Aksoy E, Taboubi S, Torres D, Delbauve S, Hachani A, Whitehead MA, et al. The p110[delta] isoform of the kinase $\mathrm{PI}(3) \mathrm{K}$ controls the subcellular compartmentalization of TLR4 signaling and protects from endotoxic shock. Nat Immunol. 2012;13(11):1045-54.

94. Yin H, Tan Y, Wu X, Yan H, Liu F, Yao Y, et al. Association between TLR4 and PTEN Involved in LPS-TLR4 Signaling Response. Biomed Res Int. 2016;2016:6083178.

95. Song MS, Salmena L, Pandolfi PP. The functions and regulation of the PTEN tumour suppressor. Nat Rev Mol Cell Biol. 2012;13(5):283-96.

96. Fenton TR, Nathanson D, Ponte de Albuquerque C, Kuga D, Iwanami A, Dang J, et al. Resistance to EGF receptor inhibitors in glioblastoma mediated by phosphorylation of the PTEN tumor suppressor at tyrosine 240. Proc Natl Acad Sci U S A. 2012;109(35):14164-9.

97. Singh AR, Peirce SK, Joshi S, Durden DL. PTEN and PI-3 kinase inhibitors control LPS signaling and the lymphoproliferative response in the CD19+ B cell compartment. Exp Cell Res. 2014;327(1):78-90.

98. Hai Ping P, Feng Bo T, Li L, Nan Hui Y, Hong Z. IL-1beta/NF-kb signaling promotes colorectal cancer cell growth through miR-181a/PTEN axis. Arch Biochem Biophys. 2016;604:20-6.

99. Oliva-Gonzalez C, Uresti-Rivera EE, Galicia-Cruz OG, Jasso-Robles FI, Gandolfi AJ, EscuderoLourdes C. The tumor suppressor phosphatase and tensin homolog protein (PTEN) is negatively regulated by NF-kappab p50 homodimers and involves histone 3 methylation/deacetylation in UROtsa cells chronically exposed to monomethylarsonous acid. Toxicol Lett. 2017;280:92-8.

100. Kawai T, Akira S. Signaling to NF-kappaB by Toll-like receptors. Trends Mol Med. 2007;13(11):460-9.

101. Xia W, Fu W, Cai X, Wang M, Chen H, Xing W, et al. Angiogenin Promotes U87MG Cell

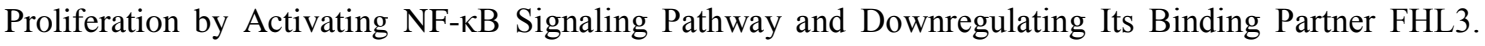
PLoS ONE. 2015;10(2):e0116983.

102. Cho HH, Song JS, Yu JM, Yu SS, Choi SJ, Kim DH, et al. Differential effect of NF- $\kappa$ B activity on $\beta$-catenin/Tcf pathway in various cancer cells. FEBS Letters. 2008;582(5):616-22.

103. Zu Y, Ping W, Deng T, Zhang N, Fu X, Sun W. Lipopolysaccharide-induced toll-like receptor 4 signaling in esophageal squamous cell carcinoma promotes tumor proliferation and regulates inflammatory cytokines expression. Dis Esophagus. 2016.

104. Cai G, Ma X, Chen B, Huang Y, Liu S, Yang H, et al. Galectin-3 induces ovarian cancer cell survival and chemoresistance via TLR4 signaling activation. Tumour Biol. 2016.

105. Lopes JA, Borges-Canha M, Pimentel-Nunes P. Innate immunity and hepatocarcinoma: Can tolllike receptors open the door to oncogenesis? World J Hepatol. 2016;8(3):162-82.

106. Dong YQ, Lu CW, Zhang L, Yang J, Hameed W, Chen W. Toll-like receptor 4 signaling promotes invasion of hepatocellular carcinoma cells through MKK4/JNK pathway. Mol Immunol. 2015;68(2 Pt C):671-83.

107. Goto Y, Arigami T, Kitago M, Nguyen SL, Narita N, Ferrone S, et al. Activation of Toll-like receptors 2, 3, and 4 on human melanoma cells induces inflammatory factors. Mol Cancer Ther. 2008;7(11):3642-53.

108. Huang B, Zhao J, Li HX, He KL, Chen YB, Mayer L, et al. Toll-like receptors on tumor cells facilitate evasion of immune surveillance. Cancer Research. 2005;65(12):5009-14.

109. Ran S. The Role of TLR4 in Chemotherapy-Driven Metastasis. Cancer Research. 2015.

110. Stojanovic I, Cuzzocrea S, Mangano K, Mazzon E, Miljkovic D, Wang M, et al. In vitro, ex vivo and in vivo immunopharmacological activities of the isoxazoline compound VGX-1027: modulation of cytokine synthesis and prevention of both organ-specific and systemic autoimmune diseases in murine models. Clin Immunol. 2007;123(3):311-23.

111. Lee JC, Menacherry S, Diehl MC, Giffear MD, White CJ, Juba R, et al. Safety, bioavailability, and pharmacokinetics of VGX-1027-A novel oral anti-inflammatory drug in healthy human subjects. Clin Pharmacol Drug Dev. 2016;5(2):91-101.

112. Liu B, Sun R, Luo H, Liu X, Jiang M, Yuan C, et al. Both intrinsic and extrinsic apoptotic 
pathways are involved in Toll-like receptor 4 (TLR4)-induced cell death in monocytic THP-1 cells. Immunobiology. 2017;222(2):198-205.

113. Salvesen GS, Walsh CM. Functions of Caspase 8: the Identified and the Mysterious. Seminars in immunology. 2014;26(3):246-52.

114. Deng S, Zhu S, Qiao Y, Liu YJ, Chen W, Zhao G, et al. Recent advances in the role of toll-like receptors and TLR agonists in immunotherapy for human glioma. Protein Cell. 2014;5(12):899-911.

115. Alvarado AG, Thiagarajan PS, Mulkearns-Hubert EE, Silver DJ, Hale JS, Alban TJ, et al. Glioblastoma Cancer Stem Cells Evade Innate Immune Suppression of Self-Renewal through Reduced TLR4 Expression. Cell Stem Cell. 2017;20(4):450-61.e4.

116. Uthaya Kumar DB, Chen CL, Liu JC, Feldman DE, Sher LS, French S, et al. TLR4 Signaling via NANOG Cooperates With STAT3 to Activate Twist1 and Promote Formation of Tumor-Initiating StemLike Cells in Livers of Mice. Gastroenterology. 2016;150(3):707-19.

117. Zeuner M-T, Krüger CL, Volk K, Bieback K, Cottrell GS, Heilemann M, et al. Biased signalling is an essential feature of TLR4 in glioma cells. Biochimica et Biophysica Acta (BBA) - Molecular Cell Research. 2016;1863(12):3084-95.

118. Gnjatic S, Sawhney NB, Bhardwaj N. Toll-like receptor agonists: are they good adjuvants? Cancer J. 2010;16(4):382-91.

119. Gabrusiewicz K, Ellert-Miklaszewska A, Lipko M, Sielska M, Frankowska M, Kaminska B. Characteristics of the alternative phenotype of microglia/macrophages and its modulation in experimental gliomas. PLoS One. 2011;6(8):e23902.

120. Gieryng A, Pszczolkowska D, Bocian K, Dabrowski M, Rajan WD, Kloss M, et al. Immune microenvironment of experimental rat C6 gliomas resembles human glioblastomas. Sci Rep. 2017;7(1):17556.

121. Garofalo S, D'Alessandro G, Chece G, Brau F, Maggi L, Rosa A, et al. Enriched environment reduces glioma growth through immune and non-immune mechanisms in mice. Nat Commun. 2015;6:6623.

122. Muller A, Brandenburg S, Turkowski K, Muller S, Vajkoczy P. Resident microglia, and not peripheral macrophages, are the main source of brain tumor mononuclear cells. Int $\mathrm{J}$ Cancer. 2015;137(2):278-88.

123. Zhu W, Carney KE, Pigott VM, Falgoust LM, Clark PA, Kuo JS, et al. Glioma-mediated microglial activation promotes glioma proliferation and migration: roles of $\mathrm{Na}+\mathrm{H}+$ exchanger isoform 1 . Carcinogenesis. 2016;37(9):839-51.

124. a Dzaye OD, Hu F, Derkow K, Haage V, Euskirchen P, Harms C, et al. Glioma Stem Cells but Not Bulk Glioma Cells Upregulate IL-6 Secretion in Microglia/Brain Macrophages via Toll-like Receptor 4 Signaling. J Neuropathol Exp Neurol. 2016;75(5):429-40.

125. Kostianovsky AM, Maier LM, Anderson RC, Bruce JN, Anderson DE. Astrocytic regulation of human monocytic/microglial activation. J Immunol. 2008;181(8):5425-32.

126. Qian J, Luo F, Yang J, Liu J, Liu R, Wang L, et al. TLR2 Promotes Glioma Immune Evasion by Downregulating MHC Class II Molecules in Microglia. Cancer Immunol Res. 2018;6(10):1220-33.

127. Hu F, Ku MC, Markovic D, a Dzaye OD, Lehnardt S, Synowitz M, et al. Glioma-associated microglial MMP9 expression is upregulated by TLR2 signaling and sensitive to minocycline. Int J Cancer. 2014;135(11):2569-78.

128. Annovazzi L, Mellai M, Bovio E, Mazzetti S, Pollo B, Schiffer D. Microglia immunophenotyping in gliomas. Oncology letters. 2018;15(1):998-1006.

129. Osterberg N, Ferrara N, Vacher J, Gaedicke S, Niedermann G, Weyerbrock A, et al. Decrease of VEGF-A in myeloid cells attenuates glioma progression and prolongs survival in an experimental glioma model. Neuro Oncol. 2016;18(7):939-49.

130. Nijaguna MB, Patil V, Urbach S, Shwetha SD, Sravani K, Hegde AS, et al. Glioblastomaderived Macrophage Colony-stimulating Factor (MCSF) Induces Microglial Release of Insulin-like Growth Factor-binding Protein 1 (IGFBP1) to Promote Angiogenesis. J Biol Chem. 2015;290(38):23401 15.

131. Mangani D, Weller M, Seyed Sadr E, Willscher E, Seystahl K, Reifenberger G, et al. Limited role for transforming growth factor-beta pathway activation-mediated escape from VEGF inhibition in murine glioma models. Neuro Oncol. 2016;18(12):1610-21.

132. Furuse M, Nonoguchi N, Kawabata S, Miyatake S, Kuroiwa T. Delayed brain radiation necrosis: pathological review and new molecular targets for treatment. Med Mol Morphol. 2015;48(4):183-90.

133. Markovic DS, Vinnakota K, Chirasani S, Synowitz M, Raguet H, Stock K, et al. Gliomas induce 
and exploit microglial MT1-MMP expression for tumor expansion. Proceedings of the National Academy of Sciences. 2009;106(30):12530-5. 


\section{Attachment}

\section{1. - Supporting information figure}

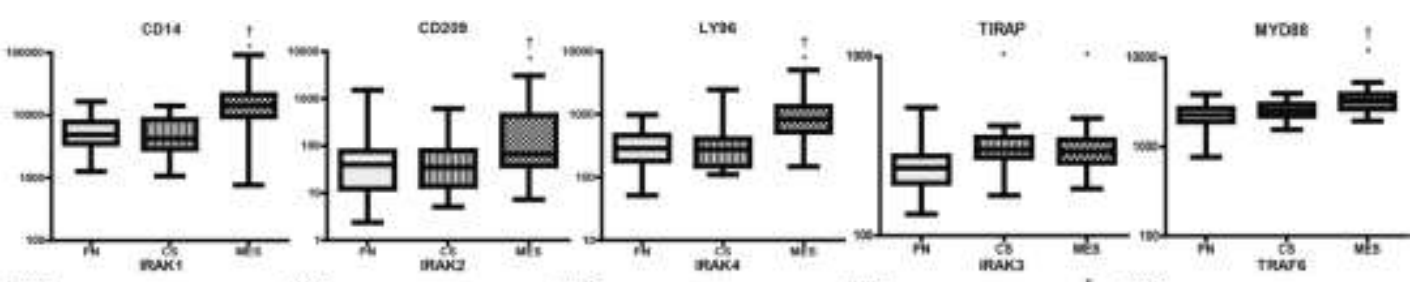

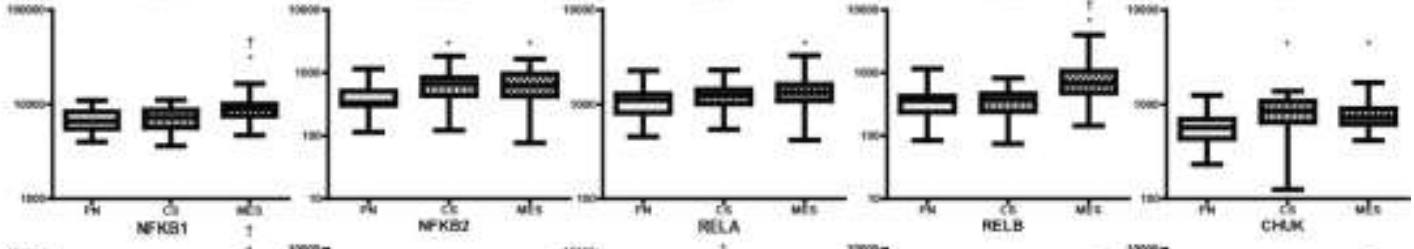

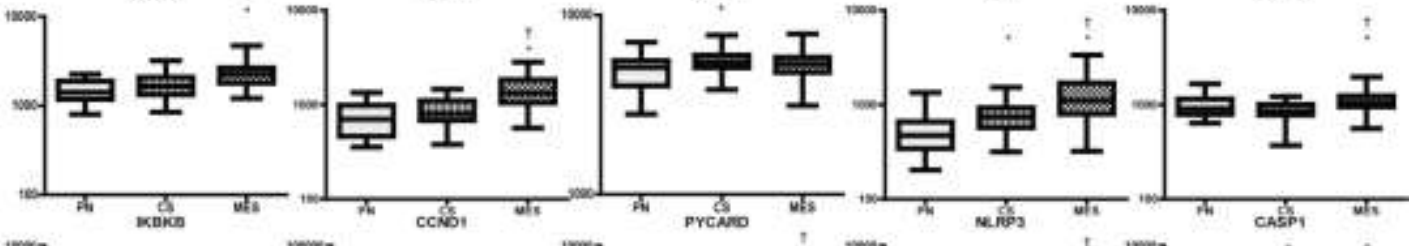

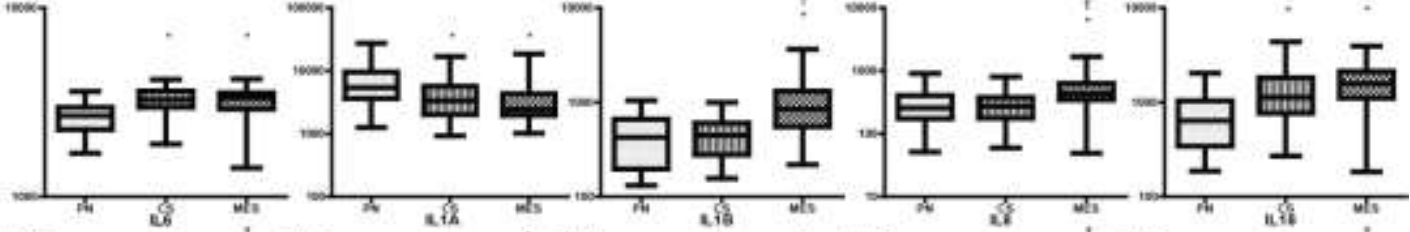

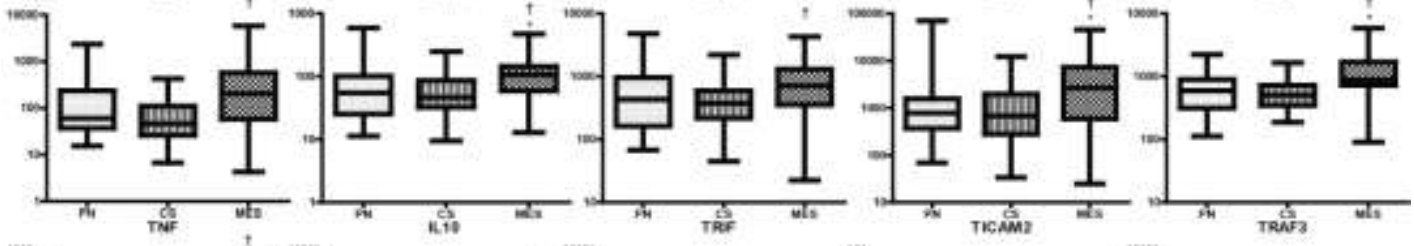

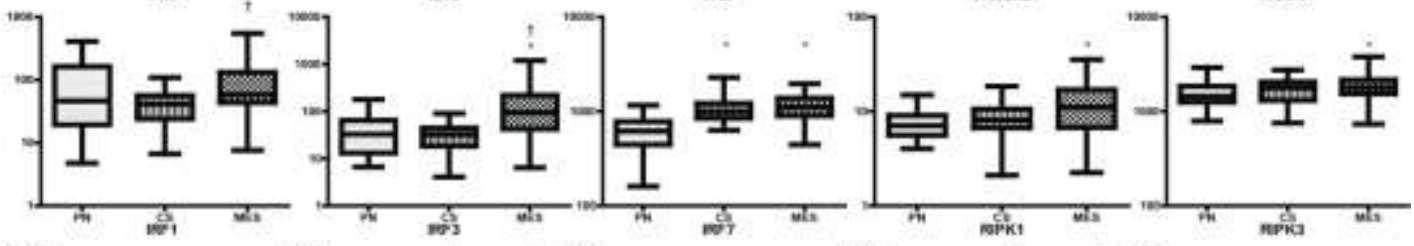

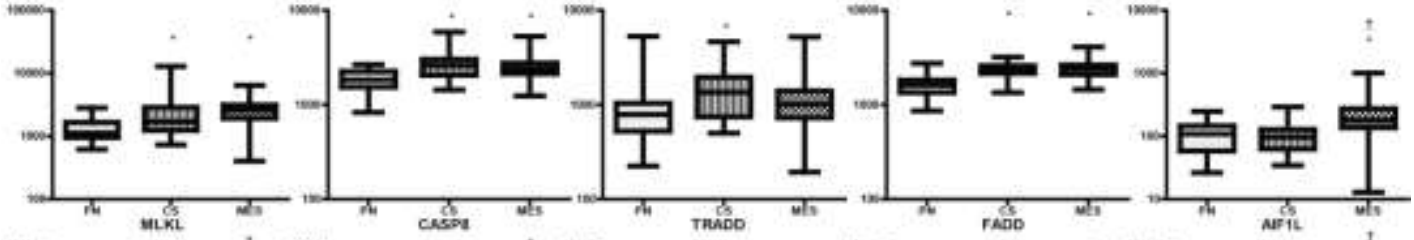

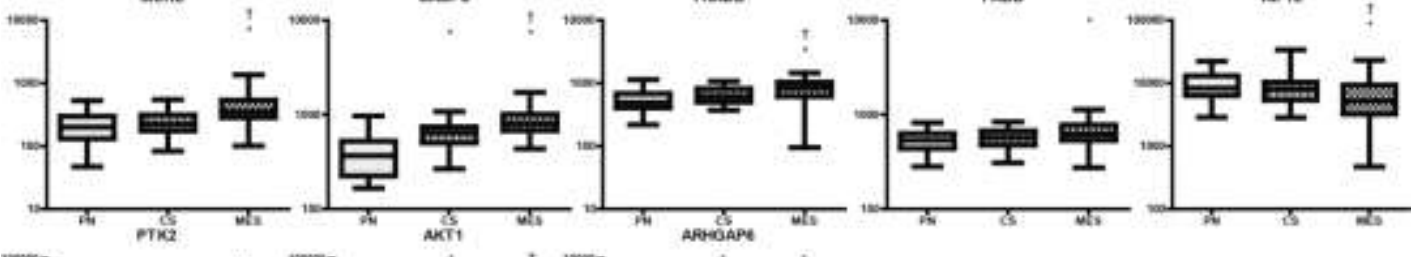

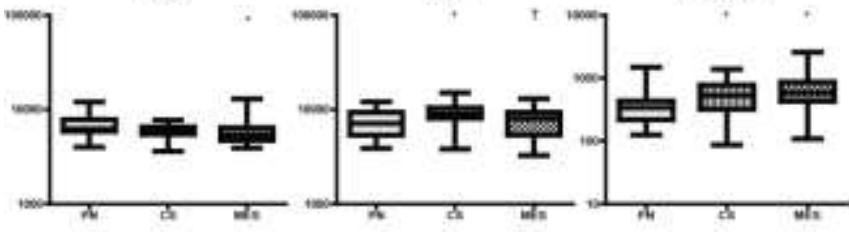


Supporting information Figure. Expression levels of the genes participating in the TLR signaling pathways categorized by GBM molecular subtypes: proneural, classical, and mesenchymal from the TCGA RNASeq dataset. The dataset is composed of 37 proneural (PN), 40 classical (CS), and 55 mesenchymal (MES) subtype cases, wherein $\left({ }^{*}\right) p<0.05$ when compared to proneural cases and $(\dagger) p<0.05$ when compared to classical cases by Kruskal-Wallis and Dunn's test. The values were normalized in DEseq. 


\title{
8.2. Attachment 2: Cep Feedback
}

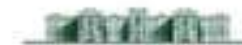 \\ MEDICINA \\ [ST) \\ COMITÊ DE ÉTICA EM PESQUISA
}

\begin{abstract}
APROVAC̣ÃO
O Comitê de Ética em Pesquisa da Faculdade de Medicina da Universidade de São Paulo, en sessìo de 04/03/2015, APROVOU o Protocolo de Pesquisa $n^{\circ}$ 059/15 intitulado: "EXPRESSŌES DOS RECEPTORES DO TIPO TOLL EM ASTROCTTOMAS HUMANOS DE DIFERENTES GRAUS DE MALIGNIDADE" apresentado pelo Departamento de NEUROLOGLA.

Cabe ao pesquisador elaborar e apresentar ao CEP. FMUSP, os relutórios pareiais e final sobre a pesquisa (Resolução do Conselho Nacional de Saúde $n^{\circ} 466 / 12$, inciso IX.2, letrn " $e "$ ).

Pesquisador (a) Responsível: Suely Kazue Nagahashi Marie

Pesquisador (a) Executante: Isabele Fattori Moretti
\end{abstract}

CEP-FMIUSP, o6 de Março de 2015.

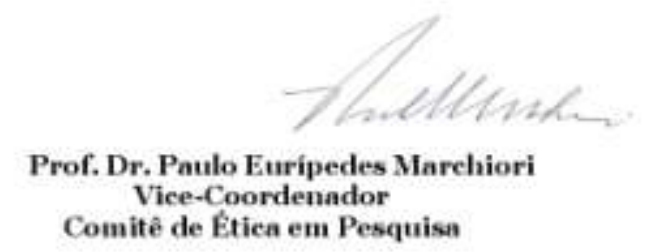

Camite de Etica em Perquisa da Faculdade de Modicina

emali: crefmefuse. 


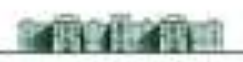 \\ MEDICINA \\ TSSP \\ COMITÊ DE ÉTICA EM PESQUISA}

\section{APROVAÇÃO}

- Comitê de Ética em Pesquisa da Faculdade de Medicina da Universidade de Săo Paulo, em sessào de 12/08/2015, APROvOU o Protocolo de Pesquisa no $\mathbf{2 7 8 / 1 5}$ intitulado: "PAPEL DO FATOR DE TRANSCRIÇÃo MITOCONDRIAL A COMO AGONISTA DE RECEPTORES TIPO TOLI EM LINHAGENS CELULARES DE GLIOBLASTOMAS" apresentado pelo Departamento de NEUROLOGLA

Cabe ao pesquisador elaborar e apresentar ao CEPFMUSP, os relatórios parciais e final sobre a pesquisa (Resoluçào do Conselho Nacional de Saude $n^{\circ} 466 / 12$, inciso $\mathrm{Lx} .2$, letra " $c$ ").

Pesquisador (a) Responsável: Suely Kazue Nagahashi Marie Pesquisador (a) Executante: Katia Guimarães Benigmo

CEP-FMUSP, 12 de Agosto de 2015 .

$$
\text { Zlenision. }
$$

Prof, Dr. Roger Chammas Coordenador Comitê de Ética em Pesquisa 


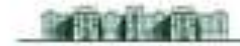 \\ MEDICINA \\ [LS] \\ COMITÊ DE ÉTICA EM PESQUISA}

\section{CIÊNCIA}

- comite de Ética em Pesquisa da facurdade de Medicina da Universidade de sáo Pavio, em sessáo de 09 de Março de 2016, TOMOU CIÊNCIA do(s) documento(s) abaixo mencionado(s) no Protocolo de Pesquisa $n^{0}$ 278/15, intituado: "Papel do Fotor de Transcriçâo Mitocondrial A como Agonista de Receptores Tipo Toll em Linhagens Celulares de Glioblastomas" apresentado peio NEUROLOGIA.

- Mudança de Pesquisador Executante para Isabele fattori Morelti

Pesquisador (a) Responsável: Suely Kazue Nagahoshi Marie

CEP-FMUSP, 09 de Março de 2016

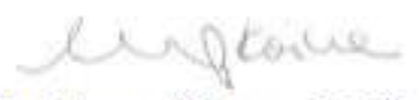

Profa. Dra. Maria Aparecida Azevedo Koilke Folgueira Coordenador

Comitê de Ética em Pesquisa 


\subsection{Attachment 3: qRT-PCR data}

\begin{tabular}{|c|c|c|c|c|c|c|c|c|c|c|c|c|c|c|c|c|c|c|c|c|c|c|c|c|c|c|c|c|}
\hline Diagnosis & Cases & Ct TLR1 & $\begin{array}{c}\text { mean } \\
\text { Ct } \\
\text { TLR1 }\end{array}$ & Ct TLR2 & $\begin{array}{c}\text { mean Ct } \\
\text { TLR2 }\end{array}$ & Ct TLR4 & $\begin{array}{c}\text { mean } \\
\text { Ct } \\
\text { TLR4 }\end{array}$ & Ct TLR5 & $\begin{array}{c}\text { mean } \\
\text { Ct } \\
\text { TLR5 }\end{array}$ & Ct TLR6 & $\begin{array}{c}\text { mean } \\
\text { Ct } \\
\text { TLR6 }\end{array}$ & Ct TBP & $\begin{array}{l}\text { mean } \\
\text { Ct TBP }\end{array}$ & Ct HPRT & $\begin{array}{c}\text { mean } \\
\text { Ct } \\
\text { HPRT }\end{array}$ & $\begin{array}{c}\text { Ct GUS- } \\
\text { b }\end{array}$ & $\begin{array}{l}\text { mean } \\
\text { Ct } \\
\text { GUS-b }\end{array}$ & $\begin{array}{c}\begin{array}{c}\text { Geometric } \\
\text { mean } \\
\text { Housekeeping }\end{array} \\
\end{array}$ & $\begin{array}{c}\text { TLR1 } \\
\Delta \mathrm{Ct}\end{array}$ & $\begin{array}{l}\text { TLR1 } \\
2^{-\Delta C T}\end{array}$ & $\begin{array}{l}\text { TLR2 } \\
\Delta C \mathrm{Ct}\end{array}$ & \begin{tabular}{|l|} 
TLR2 \\
$\mathbf{2}^{-\Delta C T}$
\end{tabular} & \begin{tabular}{c|} 
TLR4 \\
$\Delta C \mathrm{t}$
\end{tabular} & \begin{tabular}{|l|} 
TLR4 \\
$2^{-\Delta C T}$
\end{tabular} & \begin{tabular}{|c|} 
TLR5 \\
$\Delta C t$
\end{tabular} & \begin{tabular}{|l|} 
TLR5 \\
$2^{-\Delta C T}$
\end{tabular} & $\begin{array}{l}\text { TLR6 } \\
\Delta \mathrm{Ct}\end{array}$ & $\begin{array}{l}\text { TLR6 } \\
2^{-\triangle C T}\end{array}$ \\
\hline $\mathrm{NN}$ & 108 & 29.72 & 29.71 & 30.61 & 30.55 & 28.99 & 28.79 & 30.81 & 30.61 & 29.90 & 30.05 & 28.36 & 28.42 & 22.68 & 22.58 & 24.48 & 24.30 & 24.98 & 4.73 & 0.04 & 5.57 & 0.02 & 3.81 & 0.07 & 5.63 & 0.02 & 5.07 & 0.03 \\
\hline NN & 108 & 29.7 & & 30.49 & & 28.58 & & 30.41 & & 30.20 & & 28.48 & & 22.47 & & 24.11 & & & & & & & & & & & & \\
\hline NN & 132 & 29.28 & .25 & 28.17 & 28.11 & 27.40 & 27.52 & 29.24 & 29.20 & 32.66 & 32.80 & 27.66 & 27.69 & 23.93 & 23.99 & 25.02 & 25.17 & 5.57 & 3.68 & 0.08 & 2.54 & 0.17 & 1.95 & 0.26 & 3.63 & 0.08 & .23 & 0.01 \\
\hline NN & 132 & 29.21 & & 28.05 & & 27.63 & & 29.15 & & 32.94 & & 27.71 & & 24.05 & & 25.31 & & & & & & & & & & & & \\
\hline $\mathrm{NN}$ & 167 & 32.33 & 32.28 & Ind. & Ind. & 28.90 & 29.05 & 31.00 & 31.14 & Ind. & Ind. & 25.37 & 25.58 & 21.75 & 21.84 & 24.39 & 24.59 & 3.95 & 8.33 & 0.00 & Ind. & Ind. & 5.10 & 0.03 & 7.19 & 0.01 & Ind. & Ind. \\
\hline NN & 167 & 32.23 & & Ind. & & 29.19 & & 31.27 & & Ind. & & 25.79 & & 21.93 & & 24.78 & & & & & & & & & & & & \\
\hline $\mathrm{NN}$ & 173 & Ind. & Ind. & 31.01 & 30.935 & 29.49 & 29.24 & 32.49 & 32.42 & Ind. & Ind. & 28.15 & 28.2 & 24.35 & 24.51 & 26.16 & 26.33 & 26.30 & Ind. & Ind. & 4.63 & 0.04 & 2.94 & 0.13 & 6.12 & 0.01 & Ind. & Ind. \\
\hline $\mathrm{NN}$ & 173 & Ind. & & 30.86 & & 28.99 & & 32.35 & & Ind. & & 28.25 & & 24.67 & & 26.49 & & & & & & & & & & & & \\
\hline NN & 179 & 28.04 & 28.01 & 28.88 & .895 & 26.01 & 26.01 & 28.58 & 28.80 & 28.40 & 28.23 & 25.97 & 26.12 & 21.44 & 21.55 & 22.39 & 22.65 & 3 & 4.65 & 0.04 & 5.54 & 0.02 & 2.65 & 0.16 & 5.44 & 0.02 & 4.87 & 0.03 \\
\hline NN & 179 & 27.97 & & 28.91 & & 26.00 & & 29.02 & & 28.06 & & 26.27 & & 21.65 & & 22.9 & & & & & & & & & & & & \\
\hline $\mathrm{NN}$ & 189 & 28.85 & 29 & 30.39 & 30.66 & 27.42 & 27.54 & 30.87 & 30.68 & 30.23 & 30.39 & 28.07 & 28.08 & 22.96 & 23.15 & 25.39 & 25.23 & 5.40 & 3.59 & 0.08 & 5.26 & 0.03 & 2.13 & 0.23 & 5.27 & 0.03 & 4.98 & 0.03 \\
\hline NN & 189 & 29.14 & & 30.93 & & 27.65 & & 30.48 & & 30.54 & & 28.08 & & 23.33 & & 25.07 & & & & & & & & & & & & \\
\hline $\mathrm{NN}$ & 196 & 32.17 & 32.12 & 30.75 & 30.665 & 28.65 & 28.60 & 31.88 & 31.38 & Ind. & Ind. & 27.91 & 27.78 & 24.45 & 24.49 & 25.61 & 25.74 & 25.9 & 6.16 & 0.01 & 4.70 & 0.04 & 2.63 & 0.16 & 5.42 & 0.02 & Ind. & Ind. \\
\hline NN & 196 & 32.07 & & 30.58 & & 28.54 & & 30.88 & & Ind. & & 27.64 & & 24.52 & & 25.87 & & & & & & & & & & & & \\
\hline $\mathrm{NN}$ & 226 & Ind. & Ind. & 30.31 & 30.105 & 27.16 & 27.11 & 30.72 & 30.37 & 30.32 & 30.24 & 25.78 & 26.07 & 21.99 & 22.06 & 24.35 & 24.46 & .14 & Ind. & Ind. & 5.97 & 0.02 & 2.97 & 0.13 & 6.23 & 0.01 & 6.10 & 0.01 \\
\hline $\mathrm{NN}$ & 226 & Ind. & & 29.9 & & 27.06 & & 30.02 & & 30.16 & & 26.36 & & 22.13 & & 24.56 & & & & & & & & & & & & \\
\hline $\mathrm{NN}$ & 232 & 30.69 & .96 & 29.81 & 065 & 28.42 & 28.44 & 30.01 & 30.08 & 31.20 & 31.24 & 27.11 & 7.07 & 22.57 & 2.80 & 24.73 & 24.81 & 24.83 & 6.13 & 0.01 & 5.24 & 0.03 & 3.61 & 0.08 & 5.25 & 0.03 & 6.41 & 0.01 \\
\hline NN & 232 & 31.22 & & 30.32 & & 28.46 & & 30.15 & & 31.28 & & 27.02 & & 23.02 & & 24.88 & & & & & & & & & & & & \\
\hline $\mathrm{NN}$ & 237 & 30.8 & 30.82 & 29.23 & 29.145 & 28.38 & 28.59 & 31.23 & 31.15 & 31.74 & 31.69 & 26.76 & 26.61 & 22.51 & 22.61 & 22.45 & 22.53 & 23.84 & 6.98 & 0.01 & 5.31 & 0.03 & 4.75 & 0.04 & 7.31 & 0.01 & 7.85 & 0.00 \\
\hline $\mathrm{NN}$ & 237 & 30.83 & & 29.06 & & 28.79 & & \begin{tabular}{|l|}
31.07 \\
\end{tabular} & & 31.63 & & 26.45 & & 22.7 & & 22.6 & & & & & & & & & & & & \\
\hline $\mathrm{NN}$ & 245 & 31.22 & 31.31 & 30.87 & 30.845 & 29.20 & 28.97 & 31.55 & 31.35 & Ind. & Ind. & 27.23 & 27.13 & 23.54 & 23.73 & 25.25 & 25.38 & 25.37 & 5.94 & 0.02 & 5.47 & 0.02 & 3.60 & 0.08 & 5.98 & 0.02 & Ind. & Ind. \\
\hline NN & 245 & 31.4 & & 30.82 & & 28.74 & & 31.15 & & Ind. & & 27.03 & & 23.91 & & 25.51 & & & & & & & & & & & & \\
\hline $\mathrm{NN}$ & 263 & Ind. & Ind. & 33.89 & 33.78 & 30.53 & 30.50 & 34.76 & 35.60 & Ind. & Ind. & 29.08 & 29.32 & 27.11 & 27.10 & 28.08 & 28.28 & 28.22 & Ind. & Ind. & 5.56 & 0.02 & 2.28 & 0.21 & 7.38 & 0.01 & Ind. & Ind. \\
\hline NN & 263 & Ind. & & 33.67 & & 30.47 & & \begin{tabular}{|l|}
36.44 \\
\end{tabular} & & Ind. & & 29.55 & & 27.09 & & 28.47 & & & & & & & & & & & & \\
\hline $\mathrm{NN}$ & 312 & Ind. & Ind. & 30.67 & 0.61 & 28.98 & 28.79 & 31.81 & 32.20 & Ind. & Ind. & 28.45 & 28.52 & 25.92 & 26.09 & 27.54 & 27.36 & 21.0 & Ind. & Ind. & 3.30 & 0.10 & 1.48 & 0.36 & 4.89 & 0.03 & Ind. & Ind. \\
\hline $\mathrm{NN}$ & 312 & Ind. & & 30.55 & & 28.59 & & 32.58 & & Ind. & & 28.59 & & 26.26 & & 27.18 & & & & & & & & & & & & \\
\hline $\mathrm{NN}$ & 330 & Ind. & Ind. & 30 & 29.745 & 27.72 & 27.67 & 30.59 & 30.58 & Ind. & Ind. & 27.22 & 27.33 & 24.11 & 24.30 & 24.66 & 24.67 & 25.40 & Ind. & Ind. & 4.35 & 0.05 & 2.27 & 0.21 & 5.18 & 0.03 & Ind. & Ind. \\
\hline NN & 330 & Ind. & & 29.49 & & 27.62 & & 30.57 & & Ind. & & 27.43 & & 24.49 & & 24.67 & & & & & & & & & & & & \\
\hline $\mathrm{NN}$ & 332 & 34.88 & 35.15 & 31.01 & 30.76 & 30.21 & 30.34 & 33.07 & 33.15 & Ind. & Ind. & 28.63 & 28.64 & 27.95 & 28.01 & 27.54 & 27.50 & 4 & 7.11 & 0.01 & 2.72 & 0.15 & 2.29 & 0.20 & 5.10 & 0.03 & Ind. & Ind. \\
\hline $\mathrm{NN}$ & 332 & 35.42 & & 30.51 & & 30.46 & & 33.22 & & Ind. & & 28.65 & & 28.06 & & 27.46 & & & & & & & & & & & & \\
\hline $\mathrm{NN}$ & 349 & 32.18 & 32.13 & 29.26 & 29.235 & 28.46 & 28.33 & Ind. & Ind. & Ind. & Ind. & 29.85 & 29.64 & 26.89 & 26.84 & 26.17 & 26.40 & 27.59 & 4.54 & 0.04 & 1.65 & 0.32 & 0.74 & 0.60 & Ind. & Ind. & Ind. & Ind. \\
\hline NN & 349 & 32.08 & & 29.21 & & 28.20 & & Ind. & & Ind. & & 29.43 & & 26.79 & & 26.62 & & & & & & & & & & & & \\
\hline $\mathrm{NN}$ & 714 & 31.43 & 30.96 & 29.39 & 9.47 & 28.17 & 28.19 & Ind. & Ind. & Ind. & Ind. & 27.42 & 27.56 & 25.01 & 24.84 & 25.34 & 25.46 & 93 & 5.03 & 0.03 & 3.54 & 0.09 & 2.26 & 0.21 & Ind. & Ind. & Ind. & Ind. \\
\hline $\mathrm{NN}$ & 714 & 30.49 & & 29.55 & & 28.21 & & Ind. & & Ind. & & 27.7 & & 24.67 & & 25.58 & & & & & & & & & & & & \\
\hline $\mathrm{NN}$ & 755 & 30.69 & 30.36 & 27.9 & 27.945 & 27.74 & 27.54 & Ind. & In & Ind. & Ind. & 26.99 & 27.11 & 24.5 & 24.41 & 24.92 & 25.13 & 25.52 & 4.83 & 0.04 & 2.42 & 0.19 & 2.01 & 0.25 & Ind. & Ind. & Ind. & Ind. \\
\hline $\mathrm{NN}$ & 755 & 30.02 & & 27.99 & & 27.33 & & In & & Ind & & 27.22 & & 24.31 & & 25.34 & & & & & & & & & & & & \\
\hline $\mathrm{NN}$ & 805 & Ind. & Ind. & 28.4 & 28.22 & 28.15 & 28.08 & 29.89 & 30.22 & Ind. & Ind. & 26.62 & 26.88 & 24.21 & 24.32 & 24.48 & 24.66 & 25.26 & Ind. & Ind. & 2.96 & 0.13 & 2.82 & 0.14 & 4.96 & 0.03 & Ind. & Ind. \\
\hline NN & 805 & Ind. & & 28.04 & & 28.01 & & 30.54 & & Ind. & & 27.13 & & 24.42 & & 24.83 & & & & & & & & & & & & \\
\hline $\mathrm{NN}$ & 861 & Ind. & Ind. & 28.79 & 28.56 & 28.03 & 28.05 & 26.37 & 26.28 & Ind. & Ind. & 26.43 & 26.53 & 24.74 & 24.66 & 25.35 & 25.24 & 25.46 & Ind. & Ind. & 3.10 & 0.12 & 2.58 & 0.17 & 0.81 & 0.57 & Ind. & Ind. \\
\hline $\mathrm{NN}$ & 861 & Ind. & & 28.33 & & 28.06 & & 26.18 & & Ind. & & 26.62 & & 24.57 & & 25.13 & & & & & & & & & & & & \\
\hline
\end{tabular}




\begin{tabular}{|c|c|c|c|c|c|c|c|c|c|c|c|c|c|c|c|c|c|c|c|c|c|c|c|c|c|c|c|c|}
\hline Diagnosis & Cases & Ct TLR1 & $\begin{array}{c}\text { mean } \\
C t \\
\text { TLR1 }\end{array}$ & Ct TLR2 & $\begin{array}{c}\text { mean } \mathrm{Ct} \\
\text { TLR2 }\end{array}$ & Ct TLR4 & $\begin{array}{c}\text { mean } \\
C t \\
\text { TLR4 }\end{array}$ & Ct TLR5 & $\begin{array}{l}\text { mean } \\
\text { Ct } \\
\text { TLR5 }\end{array}$ & Ct TLR6 & $\begin{array}{c}\text { mean } \\
\text { Ct } \\
\text { TLR6 }\end{array}$ & Ct TBP & $\begin{array}{l}\text { mean } \\
\mathrm{Ct} \text { TBP }\end{array}$ & Ct HPRT & $\begin{array}{c}\text { mean } \\
C t \\
\text { HPRT }\end{array}$ & $\begin{array}{c}\text { Ct GUS- } \\
\text { b }\end{array}$ & $\begin{array}{l}\text { mean } \\
\text { Ct } \\
\text { GUS-b }\end{array}$ & $\begin{array}{c}\begin{array}{c}\text { Geometric } \\
\text { mean }\end{array} \\
\text { Housekeeping }\end{array}$ & $\begin{array}{l}\text { TLR1 } \\
\Delta C \mathrm{Ct}\end{array}$ & $\begin{array}{l}\text { TLR1 } \\
2^{-\Delta C T}\end{array}$ & $\begin{array}{l}\text { TLR2 } \\
\Delta C \mathrm{Ct}\end{array}$ & $\begin{array}{l}\text { TLR2 } \\
2^{-\triangle C T}\end{array}$ & $\begin{array}{l}\text { TLR4 } \\
\Delta C \mathrm{t}\end{array}$ & \begin{tabular}{|c|} 
TLR4 \\
$2^{-A C T}$
\end{tabular} & $\begin{array}{l}\text { TLR5 } \\
\Delta \mathrm{Ct}\end{array}$ & $\begin{array}{l}\text { TLR5 } \\
2^{-\triangle C T}\end{array}$ & $\begin{array}{l}\text { TLR6 } \\
\Delta C \mathrm{Ct}\end{array}$ & $\begin{array}{l}\text { TLR6 } \\
2^{-\Delta C T}\end{array}$ \\
\hline $\mathrm{NN}$ & 929 & Ind. & Ind. & 28.73 & 28.825 & 27.47 & 27.53 & Ind. & Ind. & Ind. & Ind. & 27.48 & 27.55 & 25.54 & 25.69 & 25.36 & 25.32 & 26.16 & Ind. & Ind. & 2.66 & 0.16 & 1.36 & 0.39 & & & Ind. & nd. \\
\hline $\mathrm{NN}$ & 929 & Ind. & & 28.92 & & 27.58 & & Ind. & & Ind. & & 27.61 & & 25.83 & & 25.27 & & & & & & & & & & & & \\
\hline $\mathrm{NN}$ & 969 & Ind. & Ind. & 29.01 & 28.96 & 29.04 & 28.94 & 25.93 & 26.02 & Ind. & Ind. & 27.25 & 27.25 & 24.77 & 24.89 & 25.27 & 25.40 & 25.83 & Ind. & Ind. & 3.13 & 0.11 & 3.11 & 0.12 & 0.19 & 0.87 & Ind. & Ind. \\
\hline $\mathrm{NN}$ & 969 & Ind. & & 28.91 & & 28.84 & & 26.11 & & Ind. & & 27.25 & & 25.01 & & 25.53 & & & Ind. & & & & & & & & & \\
\hline AGII & 55 & 28.49 & 28.51 & 28.2 & 28.29 & 26.12 & 26.10 & 29.10 & 29.27 & 29.52 & 29.67 & 25.94 & 26.14 & 25.43 & 25.59 & 23.97 & 24.16 & 25.28 & 3.23 & 0.11 & 3.01 & 0.12 & 0.82 & 0.57 & 3.98 & 0.06 & 4.39 & 0.05 \\
\hline AGII & 55 & 28.53 & & 28.38 & & 26.08 & & 29.43 & & 9.82 & & 26.33 & & 25.75 & & 24.35 & & & & & & & & & & & & \\
\hline AGII & 76 & 29.54 & 29.36 & 29.48 & 29.285 & 27.12 & 27.29 & 30.51 & 30.42 & 31.64 & 31.50 & 26.25 & 26.4 & 26.87 & 26.87 & 25.27 & 25.39 & 26.21 & 3.15 & 0.11 & 3.08 & 0.12 & 1.08 & 0.47 & 4.21 & 0.05 & 5.29 & 0.03 \\
\hline AGII & 76 & 29.17 & & 29.09 & & 27.46 & & 30.32 & & 31.35 & & 26.55 & & 26.86 & & 25.5 & & & & & & & & & & & & \\
\hline AGII & 101 & 29.26 & 29.37 & 27.91 & 28.015 & 28.17 & 28.27 & 28.80 & 28.73 & Ind. & Ind. & 26.33 & 26.33 & 27.18 & 27.39 & 24.46 & 24.62 & 26.09 & 3.28 & 0.10 & 1.93 & 0.26 & 2.18 & 0.22 & 2.64 & 0.16 & Ind. & Ind. \\
\hline AGII & 101 & 29.47 & & 28.12 & & 28.36 & & 28.66 & & Ind. & & 26.33 & & 27.6 & & 24.77 & & & & & & & & & & & & \\
\hline AGII & 118 & Ind. & Ind. & 32.57 & 2.65 & 30.58 & 30.68 & 31.93 & 31.94 & Ind. & Ind. & 29.56 & 29.83 & 28.99 & 29.01 & 27.83 & 27.95 & 8.92 & Ind. & Ind. & 3.73 & 0.08 & 1.76 & 0.30 & 3.02 & 0.12 & Ind. & Ind. \\
\hline AGII & 118 & Ind. & & 32.73 & & 30.77 & & 31.94 & & Ind. & & 30.1 & & 29.02 & & 28.07 & & & & & & & & & & & & \\
\hline AGII & 239 & Ind. & Ind. & 29.42 & 29.6 & 26.84 & 26.83 & 30.70 & 30.53 & Ind. & Ind. & 26.2 & 26.31 & 26.97 & 27.12 & 24.91 & 24.85 & 6.07 & Ind. & Ind. & 3.53 & 0.09 & 0.75 & 0.59 & 4.46 & 0.05 & Ind. & Ind. \\
\hline AGII & 239 & Ind. & & 29.78 & & 26.81 & & 30.36 & & Ind. & & 26.41 & & 27.27 & & 24.79 & & & & & & & & & & & & \\
\hline AGII & 250 & 32.56 & 32.49 & 31.98 & 32.195 & 29.36 & 29.23 & .11 & 33.27 & Ind. & Ind. & 28.21 & 27.92 & 25.32 & 25.50 & 26.36 & 26.45 & 6.60 & 5.88 & 0.02 & 5.59 & 0.02 & 2.63 & 0.16 & 6.66 & 0.01 & Ind. & Ind. \\
\hline AGII & 250 & 32.41 & & 32.41 & & 29.10 & & 33.42 & & Ind. & & 27.63 & & 25.67 & & 26.54 & & & & & & & & & & & & \\
\hline AGII & 254 & 30.13 & 0.14 & Ind. & Ind. & 26.24 & 26.31 & 29.06 & 29.20 & 32.29 & 32.04 & 27.35 & 7.34 & 27.18 & 27.36 & 25.67 & 26.10 & & 3.21 & 0.11 & & & -0.62 & 1.54 & 2.27 & 0.21 & 5.11 & 0.03 \\
\hline AGII & 254 & 30.15 & & Ind. & & 26.37 & & 29.33 & & 31.78 & & 27.33 & & 27.54 & & 26.52 & & & & & & & & & & & & \\
\hline AGII & 267 & 30.16 & 30.29 & 30.89 & 30.61 & 26.74 & 26.97 & 29.95 & 29.73 & Ind. & Ind. & 26.11 & 26.25 & 25.3 & 25.35 & 25.79 & 25.78 & 5.79 & 4.50 & 0.04 & 4.82 & 0.04 & 1.18 & 0.44 & 3.94 & \begin{tabular}{|l|}
0.07 \\
\end{tabular} & Ind. & Ind. \\
\hline AGII & 267 & 30.42 & & 30.33 & & 27.19 & & 29.50 & & Ind. & & 26.39 & & 25.39 & & 25.76 & & & & & & & & & & & Ind. & \\
\hline AGII & 328 & 31.72 & 31.45 & 30.49 & 30.295 & 29.57 & 29.44 & 31.25 & 31.40 & Ind. & Ind. & 27.49 & 27.38 & 24.09 & 23.99 & 26.78 & 26.70 & 88 & 5.47 & 0.02 & \begin{tabular}{|l|}
4.32 \\
\end{tabular} & 0.05 & 3.46 & 0.09 & 5.42 & 0.02 & Ind. & Ind. \\
\hline AGII & 328 & 31.18 & & 30.1 & & 29.30 & & 31.54 & & Ind. & & 27.27 & & 23.89 & & 26.61 & & & & & & & & & & & Ind. & \\
\hline AGII & 341 & 30.37 & 30.66 & 31.57 & .42 & 26.78 & 26.83 & 29.55 & 29.67 & 30.58 & 30.64 & 26.62 & 26.55 & 26.51 & 26.60 & 25.32 & 25.26 & 26.13 & 4.53 & 0.04 & 5.29 & 0.03 & 0.70 & 0.62 & 3.54 & 0.09 & 4.51 & 0.04 \\
\hline AGII & 341 & 30.95 & & 31.27 & & 26.87 & & 29.79 & & 30.69 & & 26.47 & & 26.69 & & 25.19 & & & & & & & & & & & & \\
\hline AGII & 346 & 28.07 & 7.98 & 27.59 & 65 & 27.36 & 27.53 & 28.04 & 28.13 & 29.86 & 29.85 & 27.18 & \begin{tabular}{|l|}
27.12 \\
\end{tabular} & 25.57 & 25.55 & 24.75 & 24.73 & 5.78 & 2.20 & 0.22 & 1.87 & 0.27 & 1.75 & 0.30 & 2.35 & 0.20 & 4.07 & 0.06 \\
\hline AGII & 346 & 27.89 & & 27.71 & & 27.69 & & 28.22 & & 29.84 & & 27.05 & & 25.52 & & 24.7 & & & & & & & & & & & & \\
\hline AGII & 392 & 31.68 & 31.8 & 31.2 & 31.065 & 28.97 & 28.68 & 29.29 & 29.65 & Ind. & Ind. & 26.76 & 26.92 & 25.53 & 25.48 & 26 & 26.15 & 6.17 & 5.62 & 0.02 & 4.89 & 0.03 & 2.51 & 0.18 & 3.48 & 0.09 & Ind. & Ind. \\
\hline AGII & 392 & 31.91 & & 30.93 & & 28.39 & & 30.01 & & Ind. & & 27.07 & & 25.43 & & 26.29 & & & & & & & & & & & Ind. & \\
\hline AGII & 412 & 30.76 & \begin{tabular}{|l|}
31.01 \\
\end{tabular} & 29.84 & 30.09 & 29.10 & 29.10 & 30.02 & 30.30 & 32.08 & 31.96 & 32.23 & 32.43 & 29.02 & 29.10 & 26.64 & 26.62 & 9.28 & 1.73 & 0.30 & 0.81 & 0.57 & -0.18 & 1.13 & 1.01 & 0.50 & 2.68 & 0.16 \\
\hline AGII & 412 & 31.26 & & 30.34 & & 29.10 & & 30.57 & & 31.84 & & 32.62 & & 29.17 & & 26.59 & & & & & & & & & & & & \\
\hline AGII & 452 & 28.25 & 28.37 & 26.85 & 26.885 & 25.17 & 25.18 & 28.13 & 28.18 & 29.08 & 28.87 & 26.64 & 26.68 & 26.33 & 26.54 & 24.67 & 24.95 & 0.04 & 2.32 & 0.20 & 0.84 & 0.56 & -0.87 & 1.82 & 2.14 & 0.23 & 2.82 & 0.14 \\
\hline AGII & 452 & 28.48 & & 26.92 & & 25.18 & & 28.23 & & 28.65 & & 26.71 & & 26.75 & & 25.22 & & & & & & & & & & & & \\
\hline AGII & 453 & 30.13 & 30.22 & 29.83 & 29.665 & 28.82 & 29.01 & 28.72 & 28.75 & 28.59 & 28.58 & 27.77 & 27.86 & 28.75 & 28.95 & 27.42 & 27.37 & 8.05 & 2.16 & 0.22 & 1.61 & 0.33 & 0.95 & 0.52 & 0.69 & 0.62 & 0.53 & 0.69 \\
\hline AGII & 453 & 30.3 & & 29 & & 29.19 & & 77 & & 28.57 & & 27.95 & & 2 & & 32 & & & & & & & & & & & & \\
\hline AGII & 467 & 30.09 & 30.21 & 30.11 & 30.345 & 27.19 & 27.17 & 30.08 & 30.06 & 30.11 & 30.14 & 24.88 & 25.06 & 24.62 & 24.59 & 24.96 & 24.85 & 1.83 & 5.38 & 0.02 & 5.51 & 0.02 & 2.33 & 0.20 & 5.22 & 0.03 & 5.30 & 0.03 \\
\hline AGII & 467 & 30.33 & & 30.58 & & 27.14 & & 30.03 & & 30.16 & & 25.24 & & 24 & & 24.73 & & & & & & & & & & & & \\
\hline AGII & 490 & 28.61 & 28.43 & 29.21 & 29.315 & 25.76 & 25.67 & 28.55 & 28.59 & 29.26 & 29.26 & 27.51 & 27.54 & 26.45 & 26.50 & 24.47 & 24.49 & 6.14 & 2.29 & 0.20 & 3.17 & 0.11 & -0.48 & 1.39 & 2.44 & 0.18 & 3.12 & 0.12 \\
\hline AGII & 490 & 28.25 & & 29.42 & & 25.57 & & 28.62 & & 29.26 & & 27.56 & & 26.54 & & 24.5 & & & & & & & & & & & & \\
\hline AGII & 577 & 31.29 & 31.03 & 30.19 & 95 & 27.34 & 27.28 & 30.16 & 30.12 & 31.25 & 31.46 & 27.06 & 27.15 & 26.73 & 26.94 & 24.9 & 24.90 & 31 & 4.72 & 0.04 & 3.69 & 0.08 & 0.97 & 0.51 & 3.81 & 0.07 & 5.15 & 0.03 \\
\hline AGII & 577 & 30.77 & & 29.8 & & 27.21 & & 30.08 & & 31.67 & & 27.23 & & 27.14 & & 24.89 & & & & & & & & & & & & \\
\hline
\end{tabular}




\begin{tabular}{|c|c|c|c|c|c|c|c|c|c|c|c|c|c|c|c|c|c|c|c|c|c|c|c|c|c|c|c|c|}
\hline Diagnosis & Cases & Ct TLR1 & $\begin{array}{c}\text { mean } \\
C t \\
\text { TLR1 }\end{array}$ & Ct TLR2 & $\begin{array}{c}\text { mean Ct } \\
\text { TLR2 }\end{array}$ & Ct TLR4 & $\begin{array}{c}\text { mean } \\
C t \\
\text { TLR4 }\end{array}$ & Ct TLR5 & $\begin{array}{l}\text { mean } \\
\text { Ct } \\
\text { TLR5 }\end{array}$ & Ct TLR6 & $\begin{array}{c}\text { mean } \\
\text { Ct } \\
\text { TLR6 }\end{array}$ & Ct TBP & $\begin{array}{l}\text { mean } \\
\mathrm{Ct} \text { TBP }\end{array}$ & Ct HPRT & $\begin{array}{c}\text { mean } \\
C t \\
\text { HPRT }\end{array}$ & $\begin{array}{c}\text { Ct GUS- } \\
\text { b }\end{array}$ & $\begin{array}{l}\text { mean } \\
\text { Ct } \\
\text { GUS-b }\end{array}$ & $\begin{array}{c}\begin{array}{c}\text { Geometric } \\
\text { mean }\end{array} \\
\text { Housekeeping }\end{array}$ & $\begin{array}{l}\text { TLR1 } \\
\Delta C \mathrm{Ct}\end{array}$ & $\begin{array}{l}\text { TLR1 } \\
2^{-\triangle C T}\end{array}$ & $\begin{array}{c}\text { TLR2 } \\
\Delta \mathrm{Ct}\end{array}$ & $\begin{array}{l}T^{\text {TLR2 }} \\
2^{-\Delta C T}\end{array}$ & $\begin{array}{l}\text { TLR4 } \\
\Delta \mathrm{Ct}\end{array}$ & \begin{tabular}{|c|} 
TLR4 \\
$2^{-A C T}$
\end{tabular} & $\begin{array}{l}\text { TLR5 } \\
\Delta \mathrm{Ct}\end{array}$ & $\begin{array}{l}\text { TLR5 } \\
2^{-\triangle C T}\end{array}$ & $\begin{array}{l}\text { TLR6 } \\
\Delta C \mathrm{Ct}\end{array}$ & $\begin{array}{l}\text { TLR6 } \\
2^{-\Delta C T}\end{array}$ \\
\hline$\overline{A G \|}$ & 715 & Ind. & Ind. & 32.17 & 32.37 & Ind. & Ind. & 33.49 & 33.34 & Ind. & Ind. & 31.42 & 31.37 & 27.88 & 27.78 & 27.36 & 27.34 & 28.77 & Ind. & Ind. & 3.60 & 0.08 & & & 4.57 & 0.04 & Ind. & nd. \\
\hline AGII & 715 & Ind. & & 32.57 & & Ind. & & 33.19 & & Ind. & & 31.31 & & 27.67 & & 27.31 & & & Ind. & & & & & & & & Ind. & \\
\hline AGII & 806 & 34.5 & \begin{tabular}{|l|}
34.24 \\
\end{tabular} & 31.5 & 31.35 & 29.72 & 29.56 & 33.81 & 34.05 & Ind. & Ind. & 29.43 & 29.19 & 28.56 & 28.62 & 28.01 & 28.24 & 28.68 & 5.56 & 0.02 & 2.67 & 0.16 & 0.88 & 0.54 & 5.37 & 0.02 & Ind. & Ind. \\
\hline AGII & 806 & 33.97 & & 31.2 & & 29.40 & & 34.29 & & Ind. & & 28.95 & & 28.68 & & 28.46 & & & & & & & & & & & Ind. & \\
\hline AGII & 999 & 29.81 & 9.99 & 30.03 & 9.925 & 27.39 & 27.39 & 30.09 & 30.05 & 31.14 & 30.88 & 25.74 & 25.86 & 25.46 & 25.38 & 24.89 & 24.98 & 5.40 & 4.58 & 0.04 & 4.52 & 0.04 & 1.98 & 0.25 & 4.65 & 0.04 & 5.48 & 0.02 \\
\hline AGII & 999 & 30.16 & & 29.82 & & 27.38 & & 30.01 & & 30.62 & & 25.97 & & 25.3 & & 25.06 & & & & & & & & & & & & \\
\hline AGII & 1016 & 31.97 & 2.05 & 31.91 & .85 & 29.47 & 29.44 & 31.07 & 31.07 & 32.76 & 32.95 & 26.89 & 26.77 & 27.1 & 27.08 & 26.14 & 26.20 & 26.68 & 5.37 & 0.02 & 5.17 & 0.03 & 2.76 & 0.15 & 4.39 & 0.05 & 6.27 & 0.01 \\
\hline AGII & 1016 & 32.13 & & 31.79 & & 29.41 & & 31.07 & & 33.14 & & 26.64 & & 27.06 & & 26.26 & & & & & & & & & & & & \\
\hline AGII & 1095 & 28.31 & 28.59 & 28.23 & 28.3 & 26.35 & 26.62 & 28.38 & 28.33 & 28.91 & 28.78 & 25.75 & 25.71 & 26.94 & 27.13 & 25.48 & 25.66 & 6.15 & 2.44 & 0.18 & 2.15 & 0.23 & 0.47 & 0.72 & 2.18 & 0.22 & 2.62 & 0.16 \\
\hline AGII & 1095 & 28.87 & & 28.37 & & 26.89 & & 28.28 & & 28.64 & & 25.67 & & 27.31 & & 25.83 & & & & & & & & & & & & \\
\hline AGII & 1099 & 30.55 & .55 & 29.51 & .435 & 26.07 & 26.02 & 29.43 & 29.60 & 30.66 & 30.63 & 26.69 & 6.84 & 26.03 & 26.20 & 26.55 & 26.42 & 26.49 & 4.06 & 0.06 & 2.95 & 0.13 & -0.47 & 1.39 & 3.11 & 0.12 & 4.14 & 0.06 \\
\hline AGII & 1099 & 30.55 & & 29.36 & & 25.96 & & 29.77 & & 30.59 & & 26.99 & & 26.37 & & 26.29 & & & & & & & & & & & & \\
\hline AGII & 1113 & 28.61 & 28.68 & 28.12 & 3.07 & 25.18 & 25.14 & 27.26 & 27.42 & 29.61 & 29.57 & 26.06 & 26.26 & 26.01 & 26.13 & 24.53 & 24.64 & 5.66 & 3.02 & 0.12 & 2.41 & 0.19 & -0.53 & 1.44 & 1.76 & 0.30 & 3.91 & 0.07 \\
\hline AGII & 1113 & 28.75 & & 28.02 & & 25.09 & & 27.58 & & 29.53 & & 26.45 & & 26.25 & & 24.75 & & & & & & & & & & & & \\
\hline AGII & 1155 & 29.71 & 29.7 & 27.72 & 27.88 & 27.24 & 27.20 & 28.45 & 28.61 & 30.63 & 30.53 & 26.67 & 26.84 & 24.45 & 24.45 & 24.41 & 24.65 & 5.29 & 4.41 & 0.05 & 2.59 & 0.17 & 1.91 & 0.27 & 3.32 & 0.10 & 5.24 & 0.03 \\
\hline AGII & 1155 & 29.68 & & 28.04 & & 27.16 & & 28.76 & & 30.43 & & 27 & & 24.44 & & 24.89 & & & & & & & & & & & & \\
\hline AGIII & 28 & 29.84 & 29.68 & 27.66 & 27.8 & 26.03 & 26.03 & 29.49 & 29.40 & 31.48 & 31.45 & 28.32 & 28.45 & 27.37 & 27.22 & 26.04 & 26.23 & 27.28 & 2.39 & 0.19 & 0.52 & 0.70 & -1.26 & 2.39 & 2.12 & 0.23 & 4.16 & 0.06 \\
\hline AGIII & 28 & 29.51 & & 27.94 & & 26.02 & & 29.31 & & 31.41 & & 28.58 & & 27.06 & & 26.42 & & & & & & & & & & & & \\
\hline AGIII & 34 & 31.89 & 32.15 & 30.31 & 30.41 & 28.21 & 28.25 & 32.09 & 31.93 & 33.25 & 33.33 & 26.46 & 26.6 & 26.51 & 26.58 & 24.77 & 26.75 & 6.64 & 5.51 & 0.02 & 3.77 & 0.07 & 1.61 & 0.33 & 5.29 & 0.03 & 6.69 & 0.01 \\
\hline AGIII & 34 & 32.4 & & 30.51 & & 28.29 & & 31.77 & & 33.40 & & 26.73 & & 26.64 & & 28.73 & & & & & & & & & & & & \\
\hline AGIII & 73 & 31.07 & 30.93 & 28.91 & 28.945 & 29.66 & 29.86 & 30.19 & 30.26 & 32.70 & 32.42 & 30.32 & 30.45 & 27.44 & 27.31 & 25.51 & 25.44 & 56 & 3.27 & 0.10 & 1.29 & 0.41 & 2.20 & 0.22 & 2.60 & 0.16 & 4.76 & 0.04 \\
\hline AGIII & 73 & 30.79 & & 28.98 & & 30.05 & & 30.33 & & 32.14 & & 30.58 & & 27.18 & & 25.36 & & & & & & & & & & & & \\
\hline AGIII & 233 & Ind. & Ind. & 31.26 & 1.05 & 30.35 & 30.27 & 29.95 & 29.84 & Ind. & Ind. & 29.37 & 29.3 & 26.16 & 26.33 & 25.2 & 25.71 & 7.07 & nd. & Ind. & 3.98 & 0.06 & 3.20 & 0.11 & 2.77 & 0.15 & Ind. & Ind. \\
\hline AGIII & 233 & Ind. & & 30.84 & & 30.18 & & 29.73 & & Ind. & & 29.22 & & 26.49 & & 26.22 & & & & & & & & & & & & \\
\hline AGIII & 249 & 29.38 & 9.66 & 29.18 & .24 & 27.29 & 27.57 & 29.01 & 29.04 & 31.80 & 31.75 & 26.55 & 26.75 & 24.74 & 24.81 & 23.56 & 23.61 & 5.02 & 4.63 & 0.04 & 4.22 & 0.05 & 2.55 & 0.17 & 4.01 & 0.06 & 6.72 & 0.01 \\
\hline AGIII & 249 & 29.93 & & 29.3 & & 27.85 & & 29.06 & & 31.69 & & 26.94 & & 24.88 & & 23.66 & & & & & & & & & & & & \\
\hline AGIII & 338 & 31.09 & 31.31 & 29.95 & 29.965 & 28.51 & 28.51 & 30.62 & 30.88 & Ind. & Ind. & 31.28 & 31.17 & 28.38 & 28.29 & 26.95 & 26.65 & 8.64 & 2.67 & 0.16 & 1.33 & 0.40 & -0.13 & 1.10 & 2.24 & 0.21 & Ind. & Ind. \\
\hline AGIII & 338 & 31.52 & & 29.98 & & 28.50 & & 31.14 & & Ind. & & 31.06 & & 28.19 & & 26.34 & & & & & & & & & & & & \\
\hline AGIII & 347 & 34.11 & 34.06 & 30.55 & 30.525 & 32.54 & 32.74 & 33.80 & 33.01 & Ind. & Ind. & 31.42 & 31.37 & 30.5 & 30.37 & 28.03 & 28.20 & 9.95 & 4.11 & 0.06 & 0.58 & 0.67 & 2.79 & 0.14 & 3.06 & 0.12 & Ind. & Ind. \\
\hline AGIII & 347 & 34.01 & & 30.5 & & 32.93 & & 32.22 & & Ind. & & 31.31 & & 30.24 & & 28.37 & & & & & & & & & & & & \\
\hline AGIII & 360 & 30.04 & 30.06 & 29.97 & 29.795 & 27.20 & 27.24 & 29.72 & 29.76 & 31.06 & 31.04 & 27.58 & 27.46 & 26.03 & 26.07 & 28.83 & 27.14 & 0.00 & 3.17 & 0.11 & 2.91 & 0.13 & 0.36 & 0.78 & 2.87 & 0.14 & 4.15 & 0.06 \\
\hline AGIII & 360 & 30.07 & & 29.62 & & 27.28 & & 29.79 & & 31.01 & & 27.34 & & 26.1 & & 25.44 & & & & & & & & & & & & \\
\hline AGIII & 366 & 32.14 & 32.17 & 31.31 & 31.125 & 30.87 & 30.71 & 32.48 & 33.05 & Ind. & Ind. & 28.93 & 28.86 & 27.21 & 27.30 & 24.6 & 24.64 & 6.87 & 5.30 & 0.03 & 4.25 & 0.05 & 3.84 & 0.07 & 6.18 & 0.01 & Ind. & Ind. \\
\hline AGIII & 366 & 32.2 & & 30.94 & & 30.55 & & 62 & & Ind. & & 28.78 & & 27.38 & & 24.67 & & & & & & & & & & & & \\
\hline AGIII & 410 & Ind. & Ind. & 30.22 & 30.375 & 26.04 & 25.88 & 28.57 & 28.45 & 30.05 & 30.10 & 29.12 & 29.24 & 25.99 & 26.17 & 25.2 & 25.22 & 6.82 & Ind. & Ind. & 3.56 & 0.09 & -0.94 & 1.92 & 1.63 & 0.32 & 3.28 & 0.10 \\
\hline AGIII & 410 & Ind. & & 30.53 & & 25.72 & & 28.33 & & 30.15 & & 29.36 & & 26.34 & & 25.23 & & & & & & & & & & & & \\
\hline AGIII & 428 & 31.47 & 31.42 & 29.37 & 29.38 & 30.21 & 30.20 & 31.21 & 31.26 & Ind. & Ind. & 28.25 & 28.5 & 27 & 27.20 & 25.31 & 25.41 & 7.01 & 4.41 & 0.05 & 2.37 & 0.19 & 3.19 & 0.11 & 4.25 & 0.05 & Ind. & Ind. \\
\hline AGIII & 428 & 31.36 & & 29.39 & & 30.19 & & 31.31 & & Ind. & & 28.75 & & 27.1 & & 25.5 & & & & & & & & & & & & \\
\hline AGIII & 478 & 27.22 & 2 & 26.77 & 75 & 25.69 & 25.69 & 28.34 & 28.27 & 27.56 & 27.53 & 27.12 & 27.12 & 23.86 & 23.83 & 23.22 & 23.16 & 54 & 2.56 & 0.17 & 2.23 & 0.21 & 1.05 & 0.48 & 3.63 & 0.08 & 2.89 & 0.14 \\
\hline AGIII & 478 & 27.18 & & 26.98 & & 25.69 & & 28.20 & & 27.50 & & 27.12 & & 23.8 & & 23.09 & & & & & & & & & & & & \\
\hline
\end{tabular}




\begin{tabular}{|c|c|c|c|c|c|c|c|c|c|c|c|c|c|c|c|c|c|c|c|c|c|c|c|c|c|c|c|c|}
\hline Diagnosis & Cases & Ct TLR1 & $\begin{array}{c}\text { mean } \\
C t \\
\text { TLR1 }\end{array}$ & Ct TLR2 & $\begin{array}{c}\text { mean Ct } \\
\text { TLR2 }\end{array}$ & Ct TLR4 & $\begin{array}{c}\text { mean } \\
C t \\
\text { TLR4 }\end{array}$ & Ct TLR5 & $\begin{array}{l}\text { mean } \\
\text { Ct } \\
\text { TLR5 }\end{array}$ & Ct TLR6 & $\begin{array}{c}\text { mean } \\
\text { Ct } \\
\text { TLR6 }\end{array}$ & Ct TBP & $\begin{array}{l}\text { mean } \\
\mathrm{Ct} \text { TBP }\end{array}$ & Ct HPRT & $\begin{array}{c}\text { mean } \\
C t \\
\text { HPRT }\end{array}$ & $\begin{array}{c}\text { Ct GUS- } \\
\text { b }\end{array}$ & $\begin{array}{l}\text { mean } \\
\text { Ct } \\
\text { GUS-b }\end{array}$ & $\begin{array}{c}\begin{array}{c}\text { Geometric } \\
\text { mean }\end{array} \\
\text { Housekeeping }\end{array}$ & $\begin{array}{l}\text { TLR1 } \\
\Delta C \mathrm{Ct}\end{array}$ & $\begin{array}{l}\text { TLR1 } \\
2^{-\Delta C T}\end{array}$ & $\begin{array}{c}\text { TLR2 } \\
\Delta \mathrm{Ct}\end{array}$ & $\begin{array}{l}T^{\text {TLR2 }} \\
2^{-\Delta C T}\end{array}$ & $\begin{array}{l}\text { TLR4 } \\
\Delta C \mathrm{t}\end{array}$ & \begin{tabular}{|c|} 
TLR4 \\
$2^{-A C T}$
\end{tabular} & $\begin{array}{l}\text { TLR5 } \\
\Delta \mathrm{Ct}\end{array}$ & $\begin{array}{l}\text { TLR5 } \\
2^{-\triangle C T}\end{array}$ & $\begin{array}{l}\text { TLR6 } \\
\Delta C \mathrm{Ct}\end{array}$ & $\begin{array}{l}\text { TLR6 } \\
2^{-\Delta C T}\end{array}$ \\
\hline AGIII & 514 & 26.26 & 26.16 & 26.29 & 26.345 & 24.74 & 24.76 & 27.57 & 27.67 & 28.48 & 28.62 & 27.32 & 27.15 & 25.89 & 25.88 & 23.73 & 23.92 & 5.62 & 0.54 & 0.69 & 0.73 & 0.60 & \begin{tabular}{|c|}
-0.86 \\
\end{tabular} & 1.81 & 2.05 & 0.24 & 3.00 & 0.12 \\
\hline AGIII & 514 & 26.06 & & 26.4 & & 24.78 & & 27.76 & & 28.76 & & 26.98 & & 25.87 & & 24.11 & & & & & & & & & & & & \\
\hline AGIII & 734 & 29.05 & 29.11 & 27.84 & 7.795 & 30.36 & 30.10 & 31.54 & 31.81 & 33.17 & 33.03 & 30.17 & 30.19 & 28.1 & 28.20 & 26.02 & 25.99 & 28.07 & 1.04 & 0.49 & -0.28 & 1.21 & 2.03 & 0.24 & 3.73 & 0.08 & 4.95 & 0.03 \\
\hline AGIII & 734 & 29.17 & & 27.75 & & 29.84 & & 32.07 & & 32.88 & & 30.21 & & 28.29 & & 25.95 & & & & & & & & & & & & \\
\hline AGIII & 905 & Ind. & Ind. & 30.98 & 1.085 & 30.20 & 30.05 & 31.55 & 32.05 & Ind. & Ind. & 30.56 & 30.41 & 29.36 & 29.24 & 26.64 & 26.81 & 8.78 & Ind. & Ind. & 2.31 & 0.20 & $\mid 1.27$ & 0.41 & 3.27 & 0.10 & Ind. & Ind. \\
\hline AGIII & 905 & Ind. & & 31.19 & & 29.90 & & 32.55 & & Ind. & & 30.25 & & 29.12 & & 26.97 & & & & & & & & & & & & \\
\hline AGIII & 981 & 29.6 & 29.53 & 29.06 & .005 & 28.21 & 28.18 & 30.01 & 29.84 & 31.05 & 31.25 & 26.75 & 26.9 & 25.35 & 25.42 & 24.66 & 24.85 & 25.71 & 3.82 & 0.07 & 3.30 & 0.10 & 2.47 & 0.18 & 4.13 & 0.06 & 5.54 & 0.02 \\
\hline AGIII & 981 & 29.46 & & 28.95 & & 28.14 & & 29.66 & & 31.45 & & 27.05 & & 25.48 & & 25.04 & & & & & & & & & & & & \\
\hline AGIII & 1033 & 30.15 & 30.3 & 28.9 & 28.94 & 28.85 & 28.95 & 30.03 & 29.97 & Ind. & Ind. & 27.33 & 27.48 & 27 & 27.09 & 26.02 & 26.15 & 26.90 & 3.40 & 0.09 & 2.04 & 0.24 & 2.05 & 0.24 & 3.07 & 0.12 & Ind. & Ind. \\
\hline AGIII & 1033 & 30.45 & & 28.98 & & 29.04 & & 29.91 & & Ind. & & 27.63 & & 27.17 & & 26.28 & & & & & & & & & & & & \\
\hline AGIII & 1036 & 33.16 & .05 & 32.8 & .915 & 31.32 & 31.23 & 31.89 & 31.80 & Ind. & Ind. & 31.73 & 31.84 & 29.03 & 29.22 & 27.26 & 27.34 & 29.41 & 3.64 & 0.08 & 3.51 & 0.09 & 1.82 & 0.28 & 2.39 & 0.19 & Ind. & Ind. \\
\hline AGIII & 1036 & 32.93 & & 33.03 & & 31.13 & & 31.71 & & Ind. & & 31.94 & & 29.4 & & 27.42 & & & & & & & & & & & & \\
\hline GBM & 35 & 26.17 & 26.26 & 25.18 & 25.16 & 26.28 & 26.29 & 26.67 & 26.78 & 28.71 & 28.76 & 28.12 & 28.13 & 24.61 & 24.39 & 22.58 & 22.82 & 5.01 & 1.24 & 0.42 & 0.15 & 0.90 & 1.28 & 0.41 & 1.77 & 0.29 & 3.75 & 0.07 \\
\hline GBM & 35 & 26.34 & & 25.14 & & 26.30 & & 26.89 & & 28.81 & & 28.14 & & 24.16 & & 23.05 & & & & & & & & & & & & \\
\hline GBM & 74 & 28.73 & 28.93 & 26.04 & 26.045 & 27.09 & 27.09 & 3.79 & 28.93 & 29.45 & 29.48 & 27.05 & 27.13 & 19 & 26.43 & 20.43 & 20.52 & 4.50 & 4.42 & 0.05 & 1.54 & 0.34 & 2.58 & 0.17 & 4.43 & 0.05 & 4.98 & 0.03 \\
\hline GBM & 74 & 29.12 & & 26.05 & & 27.08 & & 29.07 & & 29.51 & & 27.21 & & 26.66 & & 20.6 & & & & & & & & & & & & \\
\hline GBM & 175 & 27.23 & .38 & 27.06 & 925 & 26.71 & 26.85 & 27.59 & 27.45 & 29.61 & 29.80 & 28.34 & 28.42 & 26.51 & 5.48 & 24.17 & 23.86 & 2618 & 1.19 & 0.44 & 0.74 & 0.60 & 0.67 & 0.63 & 1.27 & 0.42 & 3.61 & 0.08 \\
\hline GBM & 175 & 27.52 & & 26.79 & & 26.99 & & 27.31 & & 29.98 & & 28.5 & & 26.45 & & 23.54 & & & & & & & & & & & & \\
\hline GBM & 194 & 27.6 & 27.52 & 27.79 & 27.595 & 26.52 & 26.61 & 27.42 & 27.46 & 29.49 & 29.69 & 27.92 & 27.9 & 25.28 & 25.36 & 22.76 & 22.72 & 5.24 & 2.28 & 0.21 & 2.36 & 0.20 & 1.37 & 0.39 & 2.22 & 0.22 & 4.45 & 0.05 \\
\hline GBM & 194 & 27.44 & & 27.4 & & 26.69 & & 27.49 & & 29.88 & & 27.88 & & 25.44 & & 22.68 & & & & & & & & & & & & \\
\hline GBM & 204 & 28.42 & 28.45 & 27.44 & 27.35 & 27.74 & 27.61 & 27.74 & 27.83 & 31.13 & 31.15 & 27.49 & 27.72 & 24.93 & 24.90 & 22.87 & 23.10 & 25.16 & 3.29 & 0.10 & 2.19 & 0.22 & 2.45 & 0.18 & 2.66 & 0.16 & 5.99 & 0.02 \\
\hline GBM & 204 & 28.48 & & 27.26 & & 27.48 & & 27.91 & & 31.17 & & 27.94 & & 24.86 & & 23.32 & & & & & & & & & & & & \\
\hline GBM & 208 & 27.73 & 7.76 & 26 & 26.1 & 27.05 & 27.05 & 27.72 & 27.72 & 30.34 & 30.47 & 29.15 & 29.23 & 25.97 & 26.07 & 23.86 & 23.93 & 6.32 & 1.43 & 0.37 & -0.22 & 1.17 & 0.72 & 0.61 & 1.40 & 0.38 & 4.14 & 0.06 \\
\hline GBM & 208 & 27.78 & & 26.2 & & 27.04 & & 27.72 & & 30.59 & & 29.31 & & 26.17 & & 24 & & & & & & & & & & & & \\
\hline GBM & 256 & 26.91 & .82 & 25.87 & .875 & 27.73 & 7.92 & 28.72 & 28.83 & 30.03 & 30.03 & 28.51 & 28.52 & 26.03 & 6.01 & 24.1 & 4.09 & 5. & 0.68 & 0.63 & -0.27 & 1.21 & $\mid 1.77$ & 0.29 & 2.69 & 0.16 & 3.88 & 0.07 \\
\hline GBM & 256 & 26.73 & & 25.88 & & 28.10 & & 28.94 & & 30.02 & & 28.53 & & 25.99 & & 24.08 & & & & & & & & & & & & \\
\hline GBM & 269 & 31.04 & 31.33 & 31.62 & 31.625 & 29.63 & 29.63 & 29.76 & 29.79 & Ind. & Ind. & 27.05 & 27.17 & 26.35 & 26.19 & 23 & 23.23 & 17 & 5.85 & 0.02 & 6.15 & 0.01 & 4.15 & 0.06 & 4.31 & 0.05 & Ind. & Ind. \\
\hline GBM & 269 & 31.61 & & 31.63 & & 29.62 & & 29.81 & & Ind. & & 27.28 & & 26.03 & & 23.45 & & & & & & & & & & & & \\
\hline GBM & 274 & 27.98 & 27.98 & 26.97 & 26.875 & 28.83 & 28.96 & 29.43 & 29.38 & Ind. & Ind. & 27.12 & 27.26 & 25.39 & 25.57 & 23.47 & 23.46 & 5.38 & 2.60 & 0.16 & 1.50 & 0.35 & 3.58 & 0.08 & 4.00 & 0.06 & Ind. & Ind. \\
\hline GBM & 274 & 27.98 & & 26.78 & & 29.08 & & 29.33 & & Ind. & & 27.39 & & 25.74 & & 23.44 & & & & & & & & & & & & \\
\hline GBM & 297 & 26.31 & 26.39 & 26.15 & 5.24 & 27.27 & 27.12 & 28.90 & 28.91 & 30.40 & 30.36 & 26.03 & 26.09 & 24.62 & 24.74 & 22.11 & 22.15 & 11 & 2.12 & 0.23 & 1.97 & 0.26 & 2.85 & 0.14 & 4.64 & 0.04 & 6.09 & 0.01 \\
\hline GBM & 297 & 26.46 & & 26.33 & & 26.97 & & 28.91 & & 30.32 & & 26.15 & & 24.86 & & 22.18 & & & & & & & & & & & & \\
\hline GBM & 317 & 30.29 & 0.06 & 28.71 & 28.565 & 27.82 & 27.77 & .00 & 29.89 & Ind. & Ind. & 29.63 & 29.86 & 23.77 & 23.76 & 24.63 & 24.64 & 5.95 & 4.10 & 0.06 & 2.61 & 0.16 & 1.82 & 0.28 & 3.93 & 0.07 & Ind. & Ind. \\
\hline GBM & 317 & 29.82 & & 28.42 & & 27.72 & & 7 & & . & & 30.09 & & 2 & & 24.64 & & & & & & & & & & & & \\
\hline GBM & 356 & 28.07 & 28.04 & 27.27 & 27.245 & 27.77 & 27.71 & 31.51 & 31.46 & 30.19 & 30.35 & 28.27 & 28.16 & 25.53 & 25.46 & 23.81 & 23.98 & 1 & 2.23 & 0.21 & 1.44 & 0.37 & 1.90 & 0.27 & 5.65 & 0.02 & 4.54 & 0.04 \\
\hline GBM & 356 & 28.01 & & 27.22 & & 27.64 & & 31.41 & & 30.50 & & 28.04 & & 25 & & 24.14 & & & & & & & & & & & & \\
\hline GBM & 370 & 28.98 & 29.07 & 28.14 & 28.085 & 27.18 & 27.16 & 28.65 & 28.74 & 30.57 & 30.57 & 28.51 & 28.55 & 25.61 & 25.78 & 22.77 & 22.90 & 5.64 & 3.43 & 0.09 & 2.45 & 0.18 & 1.52 & 0.35 & 3.10 & 0.12 & 4.93 & 0.03 \\
\hline GBM & 370 & 29.15 & & 28.03 & & 27.14 & & 28.83 & & 30.56 & & 28.59 & & 25.95 & & 23.02 & & & & & & & & & & & & \\
\hline GBM & 384 & 30.53 & 30.41 & 28.29 & 15 & 29.06 & 28.98 & 29.22 & 29.39 & Ind. & Ind. & 27.15 & 27.17 & 25.05 & 25.04 & 23.04 & 23.10 & .04 & 5.37 & 0.02 & 3.27 & 0.10 & 3.94 & 0.07 & 4.34 & 0.05 & Ind. & Ind. \\
\hline GBM & 384 & 30.29 & & 28.34 & & 28.90 & & 29.55 & & Ind. & & 27.19 & & 25.02 & & 23.15 & & & & & & & & & & & Ind. & \\
\hline
\end{tabular}




\begin{tabular}{|c|c|c|c|c|c|c|c|c|c|c|c|c|c|c|c|c|c|c|c|c|c|c|c|c|c|c|c|c|}
\hline Diagnosis & Cases & Ct TLR1 & $\begin{array}{c}\text { mean } \\
\text { Ct } \\
\text { TLR1 }\end{array}$ & Ct TLR2 & $\begin{array}{c}\text { mean } \mathrm{Ct} \\
\text { TLR2 }\end{array}$ & Ct TLR4 & $\begin{array}{c}\text { mean } \\
\text { Ct } \\
\text { TLR4 }\end{array}$ & Ct TLR5 & $\begin{array}{l}\text { mean } \\
\text { Ct } \\
\text { TLR5 }\end{array}$ & Ct TLR6 & $\begin{array}{c}\text { mean } \\
\text { Ct } \\
\text { TLR6 }\end{array}$ & Ct TBP & $\begin{array}{l}\text { mean } \\
\text { Ct TBP }\end{array}$ & Ct HPRT & $\begin{array}{c}\text { mean } \\
\text { Ct } \\
\text { HPRT }\end{array}$ & $\begin{array}{c}\text { Ct GUS- } \\
\text { b }\end{array}$ & $\begin{array}{c}\text { mean } \\
\text { Ct } \\
\text { GUS-b }\end{array}$ & $\begin{array}{c}\text { Geometric } \\
\text { mean } \\
\text { Housekeeping }\end{array}$ & $\begin{array}{l}\text { TLR1 } \\
\Delta \mathrm{Ct}\end{array}$ & \begin{tabular}{|l|} 
TLR1 \\
$\mathbf{2}^{-\Delta C T}$
\end{tabular} & $\begin{array}{l}\text { TLR2 } \\
\Delta \mathrm{Ct}\end{array}$ & $\begin{array}{l}\text { TLR2 } \\
2^{-\Delta C T}\end{array}$ & $\begin{array}{l}\text { TLR4 } \\
\Delta C \mathrm{t}\end{array}$ & $\begin{array}{c}\text { TLR4 } \\
2^{-A C T}\end{array}$ & $\begin{array}{l}\text { TLR5 } \\
\Delta \mathrm{Ct}\end{array}$ & $\begin{array}{l}\text { TLR5 } \\
2^{-\Delta C T}\end{array}$ & $\begin{array}{l}\text { TLR6 } \\
\Delta C t\end{array}$ & $\begin{array}{l}\text { TLR6 } \\
2^{-\Delta C T}\end{array}$ \\
\hline GBM & 391 & 30.26 & 30.3 & 28.75 & 28.845 & 27.54 & 27.53 & 31.29 & 31.40 & 29.15 & 29.15 & 30.27 & 30.23 & 25.86 & 25.94 & 24.11 & 23.94 & 6.58 & 3.72 & 0.08 & 2.27 & 0.21 & 0.95 & 0.52 & 4.82 & 0.04 & 2.57 & 0.17 \\
\hline GBM & 391 & 30.34 & & 28.94 & & 27.52 & & 31.50 & & 29.15 & & 30.19 & & 26.02 & & 23.76 & & & & & & & & & & & & \\
\hline GBM & 397 & 29.41 & 29.46 & 29.55 & 29.825 & 29.90 & 30.17 & 31.19 & 31.40 & 32.42 & 32.47 & 28.01 & 28.18 & 25.09 & 24.97 & 23.61 & 23.64 & 25.53 & 3.93 & 0.07 & 4.30 & 0.05 & 4.64 & 0.04 & 5.87 & 0.02 & 6.94 & 0.01 \\
\hline GBM & 397 & 29.51 & & 30.1 & & 30.43 & & 31.60 & & 32.51 & & 28.35 & & 24.84 & & 23.67 & & & & & & & & & & & & \\
\hline GBM & 405 & 29.29 & 29.22 & 28.64 & 8.815 & 27.08 & 27.14 & 29.16 & 29.17 & 29.42 & 29.53 & 25.55 & 25.29 & 23.75 & 23.68 & 22.9 & 22.83 & 3.9 & 5.31 & 0.03 & 4.91 & 0.03 & 3.23 & 0.11 & 5.26 & 0.03 & 5.62 & 0.02 \\
\hline GBM & 405 & 29.15 & & 28.99 & & 27.20 & & 29.17 & & 29.64 & & 25.03 & & 23.6 & & 22.75 & & & & & & & & & & & & \\
\hline GBM & 427 & 28.38 & 28.21 & 27.23 & .145 & 27.25 & 27.36 & 27.71 & 27.64 & 28.30 & 28.25 & 25.82 & 25.85 & 25.37 & 25.33 & 24.19 & 24.28 & 25.14 & 3.06 & 0.12 & 2.00 & 0.25 & 2.22 & 0.22 & 2.49 & 0.18 & 3.10 & 0.12 \\
\hline GBM & 427 & 28.03 & & 27.06 & & 27.47 & & 27.56 & & 28.19 & & 25.88 & & 25.29 & & 24.36 & & & & & & & & & & & & \\
\hline GBM & 442 & 28.49 & 28.62 & 27.12 & 27.125 & 28.69 & 28.91 & 27.83 & 27.70 & 29.26 & 29.29 & 27.08 & 27.19 & 24.88 & 24.83 & 22.12 & 22.22 & 4.66 & 3.96 & 0.06 & 2.47 & 0.18 & 4.25 & 0.05 & 3.04 & 0.12 & 4.63 & 0.04 \\
\hline GBM & 442 & 28.75 & & 27.13 & & 29.13 & & 27.57 & & 29.31 & & 27.3 & & 24.77 & & 22.31 & & & & & & & & & & & & \\
\hline GBM & 450 & 30.77 & 0.65 & 27.85 & .79 & 29.33 & 29.52 & 29.30 & 29.21 & 29.39 & 29.27 & 27.6 & 27.8 & 25.25 & 25.29 & 23.24 & 23.43 & 25.44 & 5.21 & 0.03 & 2.35 & 0.20 & 4.08 & 0.06 & 3.77 & 0.07 & 3.83 & 0.07 \\
\hline GBM & 450 & 30.52 & & 27.73 & & 29.70 & & 29.11 & & 29.14 & & 27.99 & & 25.32 & & 23.61 & & & & & & & & & & & & \\
\hline GBM & 458 & 29.06 & 29.04 & 28.24 & 28.26 & 29.06 & 29.06 & 28.00 & 27.88 & 29.57 & 29.81 & 28.32 & 28.31 & 25.3 & 25.36 & 23.25 & 23.36 & 5.6 & 3.44 & 0.09 & 2.66 & 0.16 & 3.46 & 0.09 & 2.28 & 0.21 & 4.21 & 0.05 \\
\hline GBM & 458 & 29.02 & & 28.28 & & 29.05 & & 27.75 & & 30.04 & & 28.3 & & 25.41 & & 23.47 & & & & & & & & & & & & \\
\hline GBM & 485 & 26.33 & 26.54 & 27.09 & 27.11 & 26.67 & 26.90 & 28.02 & 27.87 & 28.00 & 27.90 & 28.89 & 28.96 & 24.45 & 24.49 & 23.46 & 23.64 & 5.59 & 0.95 & 0.52 & 1.52 & 0.35 & 1.31 & 0.40 & 2.28 & 0.21 & 2.31 & 0.20 \\
\hline GBM & 485 & 26.74 & & 27.13 & & 27.12 & & 27.72 & & 27.79 & & 29.02 & & 24.52 & & 23.81 & & & & & & & & & & & & \\
\hline GBM & 496 & 28.47 & 28.6 & 28.58 & 28.42 & 28.20 & 28.14 & 27.07 & 27.08 & 29.56 & 9.84 & 29.1 & 9.25 & 24.98 & 25.24 & 25.92 & 25.74 & 26. & 1.92 & 0.26 & 1.74 & 0.30 & 1.46 & 0.36 & 0.40 & 0.76 & 3.16 & 0.11 \\
\hline GBM & 496 & 28.73 & & 28.26 & & 28.08 & & 27.09 & & 30.12 & & 29.39 & & 25.49 & & 25.56 & & & & & & & & & & & & \\
\hline GBM & 498 & 27.83 & 7.65 & 27.18 & .18 & 26.68 & 6.97 & 27.09 & 27.08 & 28.14 & 8.21 & 26.97 & 7.19 & 22.98 & 3.04 & 22.14 & 22.35 & & 3.55 & 0.09 & 3.08 & 0.12 & 2.86 & 0.14 & 2.98 & 0.13 & 4.10 & 0.06 \\
\hline GBM & 498 & 27.47 & & 27.18 & & 27.25 & & 27.07 & & 28.27 & & 27.4 & & 23.1 & & 22.56 & & & & & & & & & & & & \\
\hline GBM & 503 & 28.12 & 28.18 & 27.49 & 27.47 & 27.19 & 27.45 & 28.27 & 28.28 & Ind. & Ind. & 28.56 & 28.39 & 25 & 25.15 & 23.66 & 23.61 & 5.64 & 2.54 & 0.17 & 1.83 & 0.28 & 1.81 & 0.29 & 2.64 & 0.16 & Ind. & Ind. \\
\hline GBM & 503 & 28.24 & & 27.45 & & 27.70 & & 28.28 & & Ind. & & 28.22 & & 25.29 & & 23.55 & & & & & & & & & & & Ind. & \\
\hline GBM & 510 & 27.45 & 27.39 & 26.24 & 26.105 & 27.08 & 27.18 & 27.96 & 27.94 & 27.79 & 27.66 & 27.14 & 27.15 & 24.55 & 24.30 & 22.32 & 22.35 & 24.52 & 2.87 & 0.14 & 1.58 & 0.33 & 2.65 & 0.16 & 3.41 & 0.09 & 3.14 & 0.11 \\
\hline GBM & 510 & 27.33 & & 25.97 & & 27.27 & & 27.91 & & 27.53 & & 27.16 & & 24.04 & & 22.38 & & & & & & & & & & & & \\
\hline GBM & 522 & 28.01 & 28.04 & 25.36 & 25.31 & 25.90 & 25.78 & 26.74 & 26.81 & 27.15 & 6.98 & 28.57 & 28.65 & 25.52 & 25.36 & 22.33 & 21.94 & 25.16 & 2.87 & 0.14 & 0.15 & 0.90 & 0.61 & 0.65 & 1.64 & 0.32 & 1.82 & 0.28 \\
\hline GBM & 522 & 28.06 & & 25.26 & & 25.65 & & 26.87 & & 26.81 & & 28.72 & & 25.19 & & 21.55 & & & & & & & & & & & & \\
\hline GBM & 524 & 27.76 & 27.91 & 25.29 & 25.295 & 26.27 & 26.56 & 27.36 & 27.16 & 27.75 & 27.77 & 27.59 & 27.77 & 24.67 & 24.69 & 23 & 22.80 & 5.00 & 2.90 & 0.13 & 0.29 & 0.82 & 1.55 & 0.34 & 2.16 & 0.22 & 2.77 & 0.15 \\
\hline GBM & 524 & 28.05 & & 25.3 & & 26.84 & & 26.96 & & 27.79 & & 27.94 & & 24.7 & & 22.6 & & & & & & & & & & & & \\
\hline GBM & 547 & 30.41 & 30.19 & 28.24 & 28.305 & 29.25 & 29.30 & 33.28 & 32.74 & 31.11 & 30.91 & 28.11 & 28.08 & 26.3 & 26.21 & 24.93 & 25.11 & 26.44 & 3.75 & 0.07 & 1.87 & 0.27 & 2.86 & 0.14 & 6.30 & 0.01 & 4.47 & 0.05 \\
\hline GBM & 547 & 29.97 & & 28.37 & & 29.34 & & 32.19 & & 30.70 & & 28.05 & & 26.11 & & 25.28 & & & & & & & & & & & & \\
\hline GBM & 555 & 27.6 & 27.53 & 26.72 & 26.785 & 27.24 & 27.21 & 27.00 & 27.06 & 28.10 & 28.35 & 27.89 & 28.07 & 25.32 & 25.35 & 22.87 & 22.81 & 25.31 & 2.21 & 0.22 & 1.47 & 0.36 & 1.90 & 0.27 & 1.74 & 0.30 & 3.04 & 0.12 \\
\hline GBM & 555 & 27.45 & & 26.85 & & 27.18 & & 27.11 & & 28.60 & & 28.24 & & 25.37 & & 22.74 & & & & & & & & & & & & \\
\hline GBM & 573 & 31.31 & 3 & 30.5 & 455 & 31.19 & 31.31 & 32.01 & 31.66 & Ind. & Ir & 33.46 & 3.67 & 29.58 & 29.43 & 27.61 & 27.40 & 3 & 1.04 & 0.49 & 0.40 & 0.76 & 1.25 & 0.42 & 1.61 & 0.33 & Ind. & Ind. \\
\hline GBM & 573 & 30.88 & & 30.41 & & 31.42 & & 31.31 & & Ind. & & 33.88 & & 29.27 & & 27.18 & & & & & & & & & & & Ind. & \\
\hline GBM & 592 & Ind. & In & 31.32 & 31.45 & Ind. & Ind. & 34.12 & 33.92 & Ind. & Ind. & 31 & 31.11 & 30 & 29.69 & 27.09 & 27.32 & 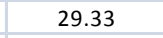 & nd. & Ind. & 2.12 & 0.23 & & & 4.59 & 0.04 & nd. & Ind. \\
\hline GBM & 592 & Ind. & & 31.58 & & III & & & & mu. & & 31.22 & & 29.37 & & 27.55 & & & tu. & & & & & & & & Ind. & \\
\hline GBM & 629 & 28.79 & 29.04 & 27.58 & 27.655 & 27.87 & 28.04 & 29.78 & 29.67 & 30.00 & 30.09 & 30.02 & 30.21 & 26.39 & 26.62 & 24.02 & 24.22 & 26.90 & 2.13 & 0.23 & 0.75 & 0.59 & 1.13 & 0.46 & 2.77 & 0.15 & 3.18 & 0.11 \\
\hline GBM & 629 & 29.28 & & 27.73 & & 28.20 & & 29.56 & & 30.17 & & 30.39 & & 26.85 & & 24.42 & & & & & & & & & & & & \\
\hline GBM & 632 & 26.96 & 26.98 & 26.58 & 26.59 & 28.05 & 28.07 & 26.70 & 26.75 & 27.46 & 27.52 & 26.45 & 26.67 & 24.19 & 24.28 & 23.1 & 23.14 & 4.65 & 2.33 & 0.20 & 1.94 & 0.26 & 3.42 & 0.09 & 2.10 & 0.23 & 2.87 & 0.14 \\
\hline GBM & 632 & 27 & & 26.6 & & 28.09 & & 26.80 & & 27.58 & & 26.88 & & 24.37 & & 23.17 & & & & & & & & & & & & \\
\hline
\end{tabular}




\begin{tabular}{|c|c|c|c|c|c|c|c|c|c|c|c|c|c|c|c|c|c|c|c|c|c|c|c|c|c|c|c|c|}
\hline $\begin{array}{l}\text { Diagnosis } \\
\end{array}$ & Cases & Ct TLR1 & $\begin{array}{c}\text { mean } \\
\text { Ct } \\
\text { TLR1 }\end{array}$ & Ct TLR2 & $\begin{array}{c}\text { mean Ct } \\
\text { TLR2 }\end{array}$ & Ct TLR4 & $\begin{array}{c}\text { mean } \\
\text { Ct } \\
\text { TLR4 }\end{array}$ & $\begin{array}{ll}\text { Ct TLR5 } \\
\end{array}$ & $\begin{array}{c}\text { mean } \\
\text { Ct } \\
\text { TLR5 }\end{array}$ & Ct TLR6 & $\begin{array}{c}\text { mean } \\
\mathrm{Ct} \\
\text { TLR6 }\end{array}$ & Ct TBP & $\begin{array}{l}\text { mean } \\
\mathrm{Ct} \text { TBP }\end{array}$ & Ct HPRT & $\begin{array}{c}\text { mean } \\
C t \\
\text { HPRT }\end{array}$ & $\begin{array}{c}\text { Ct GUS- } \\
\text { b }\end{array}$ & $\begin{array}{l}\text { mean } \\
\text { Ct } \\
\text { GUS-b }\end{array}$ & $\begin{array}{c}\text { Geometric } \\
\text { mean } \\
\text { Housekeeping }\end{array}$ & \begin{tabular}{|l|} 
TLR1 \\
$\Delta \mathrm{Ct}$
\end{tabular} & \begin{tabular}{|l|} 
TLR1 \\
$2^{-\Delta C T}$
\end{tabular} & $\begin{array}{l}\text { TLR2 } \\
\Delta \mathrm{Ct}\end{array}$ & \begin{tabular}{l|} 
TLR2 \\
$2^{-\Delta C T}$
\end{tabular} & \begin{tabular}{|c|} 
TLR4 \\
$\Delta \mathrm{Ct}$
\end{tabular} & $\begin{array}{c}\text { TLR4 } \\
2^{-A C T}\end{array}$ & \begin{tabular}{|c|} 
TLR5 \\
$\Delta \mathrm{Ct}$
\end{tabular} & \begin{tabular}{|l|} 
TLR5 \\
$\mathbf{2}^{- \text {LCT }}$
\end{tabular} & \begin{tabular}{|l|} 
TLR6 \\
$\Delta C \mathrm{Ct}$
\end{tabular} & $\begin{array}{c}\text { TLR6 } \\
2^{-\Delta C T}\end{array}$ \\
\hline GBM & 638 & 28.5 & 28.78 & 28 & 28.055 & 28.81 & 28.56 & 28.93 & 28.94 & Ind. & Ind. & 30.69 & 30.92 & 26.16 & 6.38 & 23.32 & 23.42 & 5.73 & 2.04 & 0.24 & 1.32 & 0.40 & 1.83 & 0.28 & 2.21 & 0.22 & Ind. & Ind. \\
\hline GBM & 638 & 29.05 & & 28.11 & & 28.31 & & 28.95 & & Ind. & & 31.15 & & 26.6 & & 23.52 & & & & & & & & & & & Ind. & \\
\hline GBM & 640 & 28.87 & 28.63 & 28.02 & 27.84 & 27.09 & 27.06 & 27.29 & 27.29 & 29.04 & 29.00 & 31.53 & 31.39 & 26.62 & 26.47 & 26.08 & 25.84 & 27.79 & 0.83 & 0.56 & 0.05 & 0.97 & -0.73 & 1.66 & -0.51 & 1.42 & 1.21 & 0.43 \\
\hline GBM & 640 & 28.38 & & 27.66 & & 27.03 & & 27.28 & & 28.96 & & 31.25 & & 26.32 & & 25.6 & & & & & & & & & & & & \\
\hline GBM & 642 & 29.25 & 9.27 & 29.42 & .195 & 27.48 & 27.53 & 30.45 & 30.41 & 30.21 & 30.30 & 28.37 & 28.37 & 25.65 & 25.49 & 23.47 & 23.39 & 5.67 & 3.60 & 0.08 & 3.53 & 0.09 & 1.86 & 0.28 & 4.74 & 0.04 & 4.63 & 0.04 \\
\hline GBM & 642 & 29.28 & & 28.97 & & 27.57 & & 30.37 & & 30.38 & & 28.37 & & 25.33 & & 23.3 & & & & & & & & & & & & \\
\hline GBM & 663 & Ind. & Ind. & 29.32 & .37 & 30.71 & 30.59 & 35.47 & 34.61 & Ind. & Ind. & 32.03 & 32.07 & 30.83 & 1.16 & 28.44 & 28.25 & 0.45 & Ind. & Ind. & -1.08 & 2.11 & 0.14 & 0.91 & 4.16 & 0.06 & Ind. & Ind. \\
\hline GBM & 663 & Ind. & & 29.42 & & 30.46 & & 33.75 & & Ind. & & 32.11 & & 31.48 & & 28.06 & & & Ind. & & & & & & & & Ind. & \\
\hline GBM & 684 & 29.42 & 29.41 & 28.43 & 28.405 & 27.96 & 27.85 & 28.23 & 28.46 & 29.06 & 28.94 & 29.68 & 29.89 & 24.92 & 24.74 & 22.43 & 22.69 & 5.60 & 3.81 & 0.07 & 2.81 & 0.14 & 2.25 & 0.21 & 2.86 & 0.14 & 3.34 & 0.10 \\
\hline GBM & 684 & 29.4 & & 28.38 & & 27.74 & & 28.69 & & 28.82 & & 30.09 & & 24.55 & & 22.95 & & & & & & & & & & & & \\
\hline GBM & 687 & 29.03 & .08 & 29.01 & 93 & 28.55 & 28.46 & 29.20 & .27 & Ind. & Ind. & 27.78 & 27.69 & 25.56 & 25.59 & 23.82 & 23.91 & 25.68 & 3.40 & 0.09 & 3.25 & 0.11 & 2.77 & 0.15 & 3.58 & 0.08 & Ind. & Ind. \\
\hline GBM & 687 & 29.13 & & 28.85 & & 28.36 & & 29.33 & & Ind. & & 27.6 & & 25.61 & & 23.99 & & & & & & & & & & & Ind. & \\
\hline GBM & 698 & 28.82 & 8.84 & 28.11 & 7.99 & 28.50 & 28.77 & 29.26 & 29.17 & Ind. & Ind. & 28.86 & 28.86 & 23.51 & 23.59 & 22.43 & 22.33 & 4.77 & 4.07 & 0.06 & 3.22 & 0.11 & 4.00 & 0.06 & 4.40 & 0.05 & Ind. & Ind. \\
\hline GBM & 698 & 28.85 & & 27.87 & & 29.03 & & 29.07 & & Ind. & & 28.85 & & 23.66 & & 22.22 & & & & & & & & & & & Ind. & \\
\hline GBM & 724 & Ind. & Ind. & 28.11 & 27.84 & 28.32 & 28.28 & 28.34 & 28.22 & 29.76 & 29.85 & 29.17 & 29.12 & 25.64 & 25.77 & 23.54 & 23.50 & 6.03 & Ind. & Ind. & 1.81 & 0.28 & 2.25 & 0.21 & 2.19 & 0.22 & 3.82 & 0.07 \\
\hline GBM & 724 & Ind. & & 27.57 & & 28.23 & & 28.10 & & 29.94 & & 29.07 & & 25.9 & & 23.45 & & & Ind. & & & & & & & & & \\
\hline GBM & 743 & 29.04 & 9.25 & 26.73 & 77 & 27.66 & 27.65 & 28.93 & .00 & 29.85 & 29.78 & 29.63 & 29.63 & 27.68 & .65 & 25.21 & 25.39 & 27.50 & 1.75 & 0.30 & -0.73 & 1.66 & 0.15 & 0.90 & 1.50 & 0.35 & 2.28 & 0.21 \\
\hline GBM & 743 & 29.46 & & 26.81 & & 27.64 & & 29.06 & & 29.70 & & 29.63 & & 27.61 & & 25.56 & & & & & & & & & & & & \\
\hline GBM & 750 & 27.38 & .32 & 26.08 & 07 & 27.04 & 26.84 & 28.09 & 26 & 29.06 & 28.84 & 29.14 & 29.14 & 25.12 & .30 & 22.35 & 22.38 & & 1.87 & 0.27 & 0.62 & 0.65 & 1.38 & 0.38 & 2.80 & 0.14 & 3.39 & 0.10 \\
\hline GBM & 750 & 27.26 & & 26.06 & & 26.63 & & 28.42 & & 28.62 & & 29.13 & & 25.47 & & 22.4 & & & & & & & & & & & & \\
\hline GBM & 792 & 26.57 & 26.8 & 26.88 & 26.935 & 29.32 & 29.23 & 31.14 & 31.44 & 31.65 & 31.68 & 28.52 & 28.46 & 25.56 & 25.78 & 24.2 & 24.25 & 5.10 & 0.70 & 0.62 & 0.83 & 0.56 & 3.12 & 0.11 & 5.34 & 0.02 & 5.57 & 0.02 \\
\hline GBM & 792 & 27.03 & & 26.99 & & 29.13 & & 31.74 & & 31.70 & & 28.4 & & 25.99 & & 24.29 & & & & & & & & & & & & \\
\hline GBM & 795 & 29.99 & 30.14 & 28.5 & 28.485 & 28.31 & 28.37 & 27.72 & 27.89 & 31.09 & 31.13 & 30.55 & 30.82 & 26.88 & 7.12 & 24.2 & 24.22 & 2725 & 89 & 0.14 & 1.23 & 0.43 & 1.11 & 0.46 & 0.63 & 0.65 & 3.87 & 0.07 \\
\hline GBM & 795 & 30.29 & & 28.47 & & 28.42 & & 28.05 & & 31.16 & & 31.09 & & 27.35 & & 24.24 & & & & & & & & & & & & \\
\hline GBM & 852 & 27.61 & 66 & 27.23 & 2 & 27.41 & 27.67 & 27.89 & .79 & 29.70 & 29.82 & 29.05 & 28.91 & 26.59 & 26.62 & 23.66 & 23.71 & 20.02 & 1.34 & 0.40 & 0.88 & 0.54 & 1.35 & 0.39 & 1.47 & 0.36 & 3.49 & 0.09 \\
\hline GBM & 852 & 27.71 & & 27.17 & & 27.93 & & 27.69 & & 29.93 & & 28.76 & & 26.64 & & 23.76 & & & & & & & & & & & & \\
\hline GBM & 854 & 27.54 & 27.65 & 26.67 & 26.62 & 27.89 & 27.83 & 29.19 & 29.20 & 29.42 & 29.32 & 29.2 & 29.36 & 26.35 & 26.60 & 24.14 & 24.24 & 26.65 & 1.00 & 0.50 & -0.03 & 1.02 & 1.18 & 0.44 & 2.55 & 0.17 & 2.67 & 0.16 \\
\hline GBM & 854 & 27.76 & & 26.57 & & 27.76 & & 29.21 & & 29.21 & & 29.52 & & 26.84 & & 24.33 & & & & & & & & & & & & \\
\hline GBM & 875 & 29.51 & 29.55 & 29.3 & 29.48 & 28.97 & 28.71 & 31.69 & 31.52 & Ind. & Ind. & 29.37 & 29.55 & 26.17 & 26.30 & 23.86 & 24.06 & 54 & 3.01 & 0.12 & 2.94 & 0.13 & 2.17 & 0.22 & 4.97 & 0.03 & Ind. & Ind. \\
\hline GBM & 875 & 29.59 & & 29.66 & & 28.45 & & 31.34 & & Ind. & & 29.73 & & 26.42 & & 24.26 & & & & & & & & & & & Ind. & \\
\hline GBM & 879 & 27.22 & 27.33 & 26.41 & 26.405 & 27.44 & 27.48 & 27.61 & 27.68 & 27.65 & 27.77 & 25.53 & 25.37 & 22.86 & 23.13 & 21.54 & 21.64 & 23.33 & 4.00 & 0.06 & 3.08 & 0.12 & 4.15 & 0.06 & 4.35 & 0.05 & 4.44 & 0.05 \\
\hline GBM & 879 & 27.44 & & 26.4 & & 27.51 & & \begin{tabular}{|l|}
27.74 \\
\end{tabular} & & 27.89 & & 25.21 & & 23.4 & & 21.73 & & & & & & & & & & & & \\
\hline GBM & 881 & 31.48 & 49 & 31.63 & 3 & 31.99 & 31.89 & 33.81 & 87 & Ind. & Ind. & 29.39 & 29.36 & 26.99 & .07 & 25.43 & 25.47 & & 4.24 & 0.05 & 4.20 & 0.05 & 4.64 & 0.04 & 6.62 & 0.01 & Ind. & Ind. \\
\hline GBM & 881 & 31.49 & & 31.27 & & 31.78 & & 33.93 & & Ind. & & 29.32 & & 27.14 & & 25.5 & & & & & & & & & & & Ind. & \\
\hline GBM & 884 & 28.7 & 28.52 & 26.82 & 26.915 & 28.46 & 28.18 & 30.51 & 30.40 & 28.92 & 28.78 & 27.42 & 27.57 & 25.4 & 25.51 & 23.09 & 23.24 & 25.37 & 3.14 & 0.11 & 1.54 & 0.34 & 2.81 & 0.14 & 5.03 & 0.03 & 3.40 & .09 \\
\hline GBM & 884 & 28.33 & & & & & & 30 & & & & 72 & & & & 23.38 & & & & & & & & & & & & \\
\hline GBM & 885 & 28.51 & 28.37 & 26.97 & 26.985 & 25.80 & 25.90 & 27.51 & 27.55 & 29.37 & 29.38 & 27.54 & 27.58 & 25.27 & 25.42 & 22.11 & 22.21 & 24.97 & 3.40 & 0.09 & 2.02 & 0.25 & 0.93 & 0.52 & 2.58 & 0.17 & 4.41 & 0.05 \\
\hline GBM & 885 & 28.23 & & 27 & & 26.00 & & 27.58 & & 29.38 & & 27.62 & & 25.56 & & 22.31 & & & & & & & & & & & & \\
\hline GBM & 891 & 28.09 & 28.3 & 28.99 & 28.895 & 27.66 & 27.61 & 29.81 & 29.93 & 30.48 & 30.37 & 26.63 & 26.71 & 24.14 & 24.22 & 23.05 & 23.16 & 24.65 & 3.64 & 0.08 & 4.24 & 0.05 & 2.96 & 0.13 & 5.27 & 0.03 & 5.71 & 0.02 \\
\hline GBM & 891 & 28.5 & & 28.8 & & 27.56 & & 30.04 & & 30.25 & & 26.79 & & 24.3 & & 23.26 & & & & & & & & & & & & \\
\hline
\end{tabular}




\begin{tabular}{|c|c|c|c|c|c|c|c|c|c|c|c|c|c|c|c|c|c|c|c|c|c|c|c|c|c|c|c|c|}
\hline Diagnosis & Cases & Ct TLR1 & $\begin{array}{c}\text { mean } \\
\text { Ct } \\
\text { TLR1 }\end{array}$ & Ct TLR2 & $\begin{array}{c}\text { mean } \mathrm{Ct} \\
\text { TLR2 }\end{array}$ & Ct TLR4 & $\begin{array}{c}\text { mean } \\
\text { Ct } \\
\text { TLR4 }\end{array}$ & Ct TLR5 & $\begin{array}{l}\text { mean } \\
\text { Ct } \\
\text { TLR5 }\end{array}$ & Ct TLR6 & $\begin{array}{c}\text { mean } \\
\text { Ct } \\
\text { TLR6 }\end{array}$ & Ct TBP & $\begin{array}{l}\text { mean } \\
\text { Ct TBP }\end{array}$ & Ct HPRT & $\begin{array}{c}\text { mean } \\
\text { Ct } \\
\text { HPRT }\end{array}$ & $\begin{array}{c}\text { Ct GUS- } \\
\text { b }\end{array}$ & $\begin{array}{c}\text { mean } \\
\text { Ct } \\
\text { GUS-b }\end{array}$ & $\begin{array}{c}\text { Geometric } \\
\text { mean } \\
\text { Housekeeping }\end{array}$ & $\begin{array}{l}\text { TLR1 } \\
\Delta \mathrm{Ct}\end{array}$ & \begin{tabular}{|l|} 
TLR1 \\
$\mathbf{2}^{-\Delta C T}$
\end{tabular} & $\begin{array}{l}\text { TLR2 } \\
\Delta \mathrm{Ct}\end{array}$ & $\begin{array}{l}\text { TLR2 } \\
2^{-\Delta C T}\end{array}$ & $\begin{array}{l}\text { TLR4 } \\
\Delta C \mathrm{t}\end{array}$ & $\begin{array}{c}\text { TLR4 } \\
2^{-A C T}\end{array}$ & $\begin{array}{l}\text { TLR5 } \\
\Delta \mathrm{Ct}\end{array}$ & $\begin{array}{l}\text { TLR5 } \\
2^{-\triangle C T}\end{array}$ & $\begin{array}{l}\text { TLR6 } \\
\Delta C \mathrm{Ct}\end{array}$ & $\begin{array}{l}\text { TLR6 } \\
\text { 2 }^{-\Delta C T}\end{array}$ \\
\hline GBM & 901 & Ind. & Ind. & 27.62 & 27.54 & 28.82 & 28.75 & 29.83 & 29.67 & 31.40 & 31.23 & 27.09 & 27.2 & 26.27 & 26.36 & 24.84 & 24.72 & 6.07 & Ind. & Ind. & .47 & 0.36 & 2.68 & 0.16 & 3.59 & 0.08 & 5.16 & 0.03 \\
\hline GBM & 901 & Ind. & & 27.46 & & 28.68 & & 29.50 & & 31.06 & & 27.31 & & 26.45 & & 24.6 & & & Ind. & & & & & & & & & \\
\hline GBM & 903 & 27.1 & 27.07 & 26.18 & 26.09 & 27.11 & 26.90 & 29.92 & 29.99 & 28.33 & 28.22 & 26.96 & 27.21 & 26.71 & 26.72 & 24.01 & 24.22 & 26.01 & 1.05 & 0.48 & 0.08 & 0.95 & 0.88 & 0.54 & 3.98 & 0.06 & 2.20 & 0.22 \\
\hline GBM & 903 & 27.03 & & 26 & & 26.68 & & 30.06 & & 28.10 & & 27.45 & & 26.73 & & 24.43 & & & & & & & & & & & & \\
\hline GBM & 925 & 27.36 & 7.24 & 26.91 & 26.91 & 27.40 & 27.57 & 28.21 & 28.36 & 28.58 & 28.61 & 28.87 & 28.91 & 27.13 & 27.39 & 25.1 & 25.06 & 7.07 & 0.17 & 0.89 & -0.16 & 1.12 & 0.50 & 0.71 & 1.29 & 0.41 & 1.54 & 0.34 \\
\hline GBM & 925 & 27.12 & & 26.91 & & 27.73 & & 28.50 & & 28.63 & & 28.94 & & 27.64 & & 25.01 & & & & & & & & & & & & \\
\hline GBM & 930 & 28.82 & 3.91 & 27.51 & .535 & 28.40 & 28.26 & 29.71 & 29.52 & 31.74 & 31.65 & 28.61 & 28.58 & 26.95 & 26.92 & 26.2 & 26.08 & 27.17 & 1.74 & 0.30 & 0.36 & 0.78 & 1.08 & 0.47 & 2.34 & 0.20 & 4.47 & 0.05 \\
\hline GBM & 930 & 29 & & 27.56 & & 28.11 & & 29.32 & & 31.55 & & 28.55 & & 26.89 & & 25.96 & & & & & & & & & & & & \\
\hline GBM & 1002 & 27.62 & 27.35 & 26.63 & 26.84 & 26.04 & 25.78 & 29.71 & 29.50 & 26.21 & 26.35 & 29.53 & 29.59 & 26.05 & 26.18 & 23.05 & 23.13 & 6.17 & 1.18 & 0.44 & 0.67 & 0.63 & -0.39 & 1.31 & 3.33 & 0.10 & 0.18 & 0.88 \\
\hline GBM & 1002 & 27.07 & & 27.05 & & 25.52 & & 29.28 & & 26.48 & & 29.65 & & 26.31 & & 23.2 & & & & & & & & & & & & \\
\hline GBM & 1003 & 28.66 & 28.7 & 27.75 & 475 & 27.57 & 7.65 & 28.25 & 28.29 & 29.71 & 9.53 & 28.18 & 8.19 & 25.77 & 25.65 & 24.5 & 24.51 & 26.07 & 2.63 & 0.16 & 1.40 & 0.38 & 1.57 & 0.34 & 2.22 & 0.21 & 3.46 & 0.09 \\
\hline GBM & 1003 & 28.74 & & 27.2 & & 27.72 & & 28.33 & & 29.35 & & 28.2 & & 25.53 & & 24.52 & & & & & & & & & & & & \\
\hline GBM & 1007 & 29.96 & 30 & 29.14 & 9.105 & 27.23 & 27.17 & 30.38 & 30.80 & 31.07 & 31.28 & 25.51 & 25.48 & 22.81 & 22.86 & 23.08 & 23.27 & 3.84 & 6.16 & 0.01 & 5.26 & 0.03 & 3.32 & 0.10 & 6.95 & 0.01 & 7.44 & 0.01 \\
\hline GBM & 1007 & 30.04 & & 29.07 & & 27.10 & & 31.21 & & 31.49 & & 25.45 & & 22.91 & & 23.46 & & & & & & & & & & & & \\
\hline GBM & 1009 & 30.3 & 30.22 & 27.8 & 27.695 & 27.83 & 27.87 & 29.55 & 29.27 & 31.19 & 31.30 & 27.39 & 27.42 & 24.01 & 24.03 & 22.08 & 22.23 & 4.47 & 5.75 & 0.02 & 3.23 & 0.11 & 3.40 & 0.09 & 4.80 & 0.04 & 6.83 & 0.01 \\
\hline GBM & 1009 & 30.13 & & 27.59 & & 27.91 & & 28.99 & & 31.41 & & 27.45 & & 24.05 & & 22.37 & & & & & & & & & & & & \\
\hline GBM & 1018 & Ind. & In & 31.68 & .78 & 33.64 & 33.56 & 32.18 & 32.10 & 33.11 & 3.15 & 31.38 & 1.39 & 30.49 & 30.71 & 29.37 & 29.36 & 30.47 & nd. & Ind. & 1.31 & 0.40 & 3.09 & 0.12 & 1.63 & 0.32 & 2.68 & 0.16 \\
\hline GBM & 1018 & Ind. & & 31.88 & & 33.47 & & 32.01 & & 33.18 & & 31.39 & & 30.92 & & 29.34 & & & nd. & & & & & & & & & \\
\hline GBM & 1070 & 29.52 & 9.37 & 27.81 & 925 & 27.26 & 7.18 & 28.17 & 28.16 & 30.94 & 1.18 & 26.09 & 5.13 & 25.05 & 5.17 & 22.49 & 22.66 & & 4.77 & 0.04 & 3.32 & 0.10 & 2.58 & 0.17 & 3.55 & 0.09 & 6.58 & 0.01 \\
\hline GBM & 1070 & 29.22 & & 28.04 & & 27.10 & & 28.14 & & 31.42 & & 26.16 & & 25.28 & & 22.82 & & & & & & & & & & & & \\
\hline GBM & 1074 & 28.85 & 28.75 & 28.09 & 27.845 & 26.17 & 26.44 & 28.03 & 28.14 & 28.16 & 28.05 & 28.78 & 28.71 & 25.26 & 25.25 & 23.35 & 23.32 & 56 & 3.08 & 0.12 & 2.18 & 0.22 & 0.78 & 0.58 & 2.47 & 0.18 & 2.38 & 0.19 \\
\hline GBM & 1074 & 28.64 & & 27.6 & & 26.71 & & 28.24 & & 27.93 & & 28.64 & & 25.24 & & 23.28 & & & & & & & & & & & & \\
\hline GBM & \begin{tabular}{|l|l|} 
& 1077 \\
\end{tabular} & 28.93 & 28.75 & 27.26 & .155 & 27.29 & 27.01 & 26.63 & 26.59 & 29.13 & 29.13 & 27.51 & 27.4 & 25.46 & 25.69 & 21.51 & 21.55 & 2475 & 3.99 & 0.06 & 2.40 & 0.19 & 2.26 & 0.21 & 1.84 & 0.28 & 4.38 & 0.05 \\
\hline GBM & 1077 & 28.56 & & 27.05 & & 26.73 & & 26.55 & & 29.13 & & 27.29 & & 25.92 & & 21.59 & & & & & & & & & & & & \\
\hline GBM & 1084 & 29.11 & 9.31 & 27.41 & 7.43 & 28.23 & 28.32 & 30.46 & 30.26 & Ind. & mu. & 29.77 & 29.85 & 26.94 & 26.89 & 25.27 & 25.32 & 27.29 & 2.02 & 0.25 & 0.14 & 0.91 & 1.03 & 0.49 & 2.97 & 0.13 & Ind. & Ind. \\
\hline GBM & 1084 & 29.51 & & 27.45 & & 28.41 & & 30.06 & & Ind. & & 29.92 & & 26.83 & & 25.37 & & & & & & & & & & & Ind. & \\
\hline GBM & 1091 & 29.77 & 29.53 & 28.51 & 28.48 & 25.98 & 26.07 & 27.71 & 27.66 & 29.29 & 29.34 & 28.42 & 28.63 & 24.14 & 24.16 & 20.67 & 20.68 & 4.2 & 5.26 & 0.03 & 4.21 & 0.05 & 1.80 & 0.29 & 3.39 & 0.10 & 5.07 & 0.03 \\
\hline GBM & 1091 & 29.29 & & 28.45 & & 26.16 & & 27.60 & & 29.39 & & 28.83 & & 24.17 & & 20.68 & & & & & & & & & & & & \\
\hline GBM & 1103 & 27.93 & 27.83 & 27.15 & 27.175 & 26.85 & 27.02 & 27.39 & 27.32 & 28.69 & 28.70 & 28.11 & 28.14 & 25.24 & 25.45 & 23.29 & 23.49 & 5.62 & 2.20 & 0.22 & 1.55 & 0.34 & 1.40 & 0.38 & 1.69 & 0.31 & 3.07 & 0.12 \\
\hline GBM & 1103 & 27.72 & & 27.2 & & 27.19 & & 27.24 & & 28.70 & & 28.16 & & 25.66 & & 23.69 & & & & & & & & & & & & \\
\hline GBM & 1118 & Ind. & mu. & 30.35 & 30.47 & 29.73 & 29.89 & 31.85 & 31.88 & 31.79 & 31.96 & 31.58 & 31.3 & 28.3 & 28.41 & 26.41 & 26.35 & 0.02 & nd. & Ind. & 1.85 & 0.28 & 1.27 & 0.41 & 3.26 & 0.10 & 3.34 & 0.10 \\
\hline GBM & 1118 & Ind. & & 30.59 & & 30.04 & & 31.91 & & 32.12 & & 31.02 & & 28.52 & & 26.29 & & & Ind. & & & & & & & & & \\
\hline GBM & 1122 & 27.07 & 04 & 26.35 & 2 & 25.61 & 5.67 & 60 & 26.49 & 27.24 & 7.30 & 27.62 & 7.46 & 24.44 & 48 & 22.91 & 22.90 & & 2.16 & 0.22 & 1.44 & 0.37 & 0.80 & 0.58 & 1.62 & 0.33 & 2.42 & 0.19 \\
\hline GBM & 1122 & 27 & & 26.27 & & 25.73 & & 26.38 & & 27.35 & & 27.29 & & 24.52 & & 22.89 & & & & & & & & & & & & \\
\hline GBM & 1123 & 28.99 & 29.06 & 28.52 & 28.6 & 29.39 & 29.32 & 29.68 & 29.41 & 32.00 & 31.82 & 27.59 & 27.35 & 25.69 & 25.86 & 23.36 & 23.37 & 25.47 & 3.59 & 0.08 & 3.13 & 0.11 & 3.85 & 0.07 & 3.94 & 0.07 & 6.35 & 0.01 \\
\hline GBM & 1123 & & & & & & & & & & & 27.1 & & & & & & & & & & & & & & & & \\
\hline GBM & 1124 & 29.02 & 29.04 & 30.47 & 30.365 & 26.78 & 26.94 & 28.47 & 28.31 & 28.67 & 28.84 & 27.4 & 27.23 & 24.66 & 24.75 & 24.65 & 24.51 & 25.47 & 3.57 & 0.08 & 4.90 & 0.03 & 1.47 & 0.36 & 2.84 & 0.14 & 3.37 & 0.10 \\
\hline GBM & 1124 & 29.05 & & 30.26 & & 27.09 & & 28.14 & & 29.01 & & 27.05 & & 24.84 & & 24.37 & & & & & & & & & & & & \\
\hline GBM & 1133 & Ind. & Ind. & 28.89 & 29.02 & 30.51 & 30.82 & 30.06 & 30.26 & Ind. & Ind. & 26.27 & 26.48 & 25.78 & 25.90 & 23.26 & 23.41 & 25.23 & Ind. & Ind. & 3.79 & 0.07 & 5.59 & 0.02 & 5.03 & 0.03 & Ind. & Ind. \\
\hline GBM & 1133 & Ind. & & 29.15 & & 31.12 & & 30.46 & & Ind. & & 26.69 & & 26.02 & & 23.56 & & & Ind. & & & & & & & & Ind. & \\
\hline
\end{tabular}




\begin{tabular}{|c|c|c|c|c|c|c|c|c|c|c|c|c|c|c|c|c|c|c|c|c|c|c|c|c|c|c|c|c|}
\hline Diagnosis & Cases & Ct TLR1 & $\begin{array}{c}\text { mean } \\
\mathrm{Ct} \\
\text { TLR1 }\end{array}$ & Ct TLR2 & $\begin{array}{l}\text { mean Ct } \\
\text { TLR2 }\end{array}$ & Ct TLR4 & $\begin{array}{c}\text { mean } \\
\mathrm{Ct} \\
\text { TLR4 }\end{array}$ & Ct TLR5 & $\begin{array}{c}\text { mean } \\
\text { Ct } \\
\text { TLR5 }\end{array}$ & Ct TLR6 & $\begin{array}{l}\text { mean } \\
\mathrm{Ct} \\
\text { TLR6 }\end{array}$ & Ct TBP & $\begin{array}{l}\text { mean } \\
\text { Ct TBP }\end{array}$ & Ct HPRT & $\begin{array}{c}\text { mean } \\
\text { Ct } \\
\text { HPRT }\end{array}$ & $\begin{array}{c}\text { Ct GUS- } \\
\text { b }\end{array}$ & $\begin{array}{l}\text { mean } \\
\text { Ct } \\
\text { GUS-b }\end{array}$ & $\begin{array}{c}\text { Geometric } \\
\text { mean } \\
\text { Housekeeping }\end{array}$ & $\begin{array}{l}\text { TLR1 } \\
\Delta \mathrm{Ct}\end{array}$ & $\begin{array}{l}\text { TLR1 } \\
2^{-\Delta C T}\end{array}$ & $\begin{array}{l}\text { TLR2 } \\
\Delta \mathrm{Ct}\end{array}$ & $\begin{array}{l}\text { TLR2 } \\
2^{-\Delta C T}\end{array}$ & \begin{tabular}{|c|} 
TLR4 \\
$\Delta \mathrm{Ct}$
\end{tabular} & $\begin{array}{l}\text { TLR4 } \\
2^{- \text {-CCT }}\end{array}$ & $\begin{array}{l}\text { TLR5 } \\
\Delta \mathrm{Ct}\end{array}$ & $\begin{array}{l}\text { TLR5 } \\
2^{-\triangle C T}\end{array}$ & $\begin{array}{l}\text { TLR6 } \\
\Delta \mathrm{Ct}\end{array}$ & $\begin{array}{l}\text { TLR6 } \\
2^{-\Delta C T}\end{array}$ \\
\hline GBM & 1144 & 27.57 & 27.58 & 27.91 & 27.9 & 25.88 & 25.84 & 28.81 & 28.72 & 28.15 & 28.23 & 26.46 & 26.47 & 23.38 & 23.49 & 24.05 & 24.15 & 24.67 & 2.91 & 0.13 & 3.23 & 0.11 & 1.17 & 0.44 & 4.05 & 0.06 & 3.56 & 0.08 \\
\hline GBM & 1144 & 27.58 & & 27.89 & & 25.80 & & 28.63 & & 28.30 & & 26.47 & & 23.59 & & 24.25 & & & & & & & & & & & & \\
\hline GBM & 1161 & 27.63 & 27.79 & 26.66 & 26.625 & 25.25 & 25.34 & 27.15 & 27.20 & 29.45 & 29.40 & 27.15 & 27.16 & 24.58 & 24.64 & 22.54 & 22.82 & 24.81 & 2.98 & 0.13 & 1.82 & 0.28 & 0.53 & 0.69 & 2.39 & 0.19 & 4.59 & 0.04 \\
\hline GBM & 1161 & 27.94 & & 26.59 & & 25.42 & & 27.24 & & 29.35 & & 27.17 & & 24.69 & & 23.1 & & & & & & & & & & & & \\
\hline GBM & 1162 & 27.58 & 7.56 & 28.4 & .29 & 26.16 & 26.12 & 27.54 & 27.47 & 28.84 & 28.71 & 27.33 & 27.15 & 24.57 & 24.80 & 24.22 & 24.27 & 37 & 2.18 & 0.22 & 2.92 & 0.13 & 0.74 & 0.60 & 2.09 & 0.23 & 3.33 & .10 \\
\hline GBM & 1162 & 27.53 & & 28.18 & & 26.07 & & 27.39 & & 28.57 & & 26.96 & & 25.03 & & 24.31 & & & & & & & & & & & & \\
\hline GBM & 1169 & 27.51 & 27.49 & 26.94 & 26.91 & 24.43 & 24.62 & 28.54 & 28.64 & 28.21 & 28.12 & 27.04 & 27.2 & 24.26 & 24.37 & 22.61 & 22.50 & 4.61 & 2.88 & 0.14 & 2.30 & 0.20 & 0.00 & 1.00 & 4.03 & 0.06 & 3.50 & 0.09 \\
\hline GBM & 1169 & 27.47 & & 26.88 & & 24.80 & & 28.74 & & 28.02 & & 27.35 & & 24.47 & & 22.39 & & & & & & & & & & & & \\
\hline GBM & 1190 & 27.05 & 27.12 & 26.61 & 26.555 & 27.38 & 27.22 & 27.22 & 27.25 & 28.13 & 28.15 & 25.52 & 25.46 & 23.82 & 23.87 & 22.08 & 22.26 & 3.82 & 3.29 & 0.10 & 2.73 & 0.15 & 3.39 & 0.10 & 3.42 & 0.09 & 4.33 & 0.05 \\
\hline GBM & 1190 & 27.18 & & 26.5 & & 27.05 & & 27.27 & & 28.17 & & 25.39 & & 23.91 & & 22.43 & & & & & & & & & & & & \\
\hline GBM & 1194 & Ind. & Ind. & 32.55 & .34 & 31.73 & 31.59 & 32.09 & 32.68 & Ind. & Ind. & 30.46 & 30.43 & 28.7 & 28.72 & 25.49 & 25.60 & 28.18 & Ind. & Ind. & 4.16 & 0.06 & 3.41 & 0.09 & 4.50 & 0.04 & Ind. & Ind. \\
\hline GBM & 1194 & Ind. & & 32.13 & & 31.44 & & 33.27 & & Ind. & & 30.39 & & 28.74 & & 25.71 & & & Ind. & & & & & & & & Ind. & \\
\hline GBM & 1199 & Ind. & Ind. & 33.54 & 33.043 & 31.34 & 31.41 & 33.11 & 32.96 & Ind. & Ind. & 30.07 & 30.09 & 30.06 & 30.16 & 27.5 & 27.56 & 29.24 & Ind. & Ind. & 3.80 & 0.07 & 2.17 & 0.22 & 3.72 & 0.08 & Ind. & Ind. \\
\hline GBM & 1199 & Ind. & & 33.95 & & 31.48 & & 32.81 & & Ind. & & 30.11 & & 30.26 & & 27.61 & & & Ind. & & & & & & & & Ind. & \\
\hline GBM & 1205 & 35.22 & 35.16 & 33.14 & 33.28 & Ind. & Ind. & 34.34 & 34.28 & Ind. & Ind. & 30.8 & 30.89 & 29.84 & 29.91 & 27.33 & 27.31 & 9.33 & 5.83 & 0.02 & 3.95 & 0.06 & & & 4.95 & 0.03 & Ind. & Ind. \\
\hline GBM & 1205 & 35.1 & & 33.42 & & Ind. & & 34.22 & & Ind. & & 30.97 & & 29.98 & & 27.28 & & & & & & & & & & & Ind. & \\
\hline GBM & 1212 & 28.8 & 28.67 & 28.52 & 28.475 & 27.10 & 26.92 & 29.04 & 28.79 & 29.82 & 29.64 & 26.68 & 26.85 & 24.89 & 25.08 & 23.27 & 23.38 & .0 & 3.61 & 0.08 & 3.42 & 0.09 & 1.86 & 0.28 & 3.73 & 0.08 & 4.58 & 0.04 \\
\hline GBM & 1212 & 28.53 & & 28.43 & & 26.73 & & 28.53 & & 29.46 & & 27.02 & & 25.26 & & 23.48 & & & & & & & & & & & & \\
\hline GBM & 1232 & 26.25 & 26.14 & 25.07 & 25 & 24.83 & 24.86 & 26.20 & 26.15 & 27.43 & 27.29 & 26.12 & 26.18 & 23.38 & 23.43 & 21.66 & 21.75 & 3.72 & 2.42 & 0.19 & 1.28 & 0.41 & 1.14 & 0.45 & 2.43 & 0.19 & 3.57 & 0.08 \\
\hline GBM & 1232 & 26.03 & & 24.93 & & 24.89 & & 26.09 & & 27.15 & & 26.24 & & 23.48 & & 21.84 & & & & & & & & & & & & \\
\hline GBM & 1237 & 29.3 & 29.21 & 28.24 & 28.28 & 28.17 & 28.03 & 29.09 & 29.17 & 31.10 & 31.36 & 26.22 & 26.19 & 23.78 & 23.90 & 22.95 & 23.13 & 37 & 4.84 & 0.04 & 3.91 & 0.07 & 3.66 & 0.08 & 4.80 & 0.04 & 6.99 & 0.01 \\
\hline GBM & 1237 & 29.11 & & 28.32 & & 27.89 & & 29.24 & & 31.62 & & 26.15 & & 24.02 & & 23.3 & & & & & & & & & & & & \\
\hline GBM & 1243 & 28.07 & 28.11 & 26.2 & 26.275 & 26.91 & 26.76 & 28.30 & 28.14 & 29.61 & 29.48 & 26.35 & 26.42 & 24.93 & 25.03 & 23.24 & 23.50 & 24.95 & 3.15 & 0.11 & 1.32 & 0.40 & 1.80 & 0.29 & 3.18 & 0.11 & 4.52 & 0.04 \\
\hline GBM & 1243 & 28.14 & & 26.35 & & 26.60 & & 27.97 & & 29.34 & & 26.49 & & 25.12 & & 23.76 & & & & & & & & & & & & \\
\hline GBM & 1250 & 26.57 & 26.6 & 25.41 & 25.47 & 26.30 & 26.27 & 27.49 & 27.47 & 28.36 & 28.34 & 27.36 & 27.56 & 23.87 & 24.01 & 22.74 & 22.93 & 24.75 & 1.84 & 0.28 & 0.72 & 0.61 & 1.52 & 0.35 & 2.72 & 0.15 & 3.58 & 0.08 \\
\hline GBM & 1250 & 26.62 & & 25.53 & & 26.24 & & 27.45 & & 28.31 & & 27.76 & & 24.15 & & 23.11 & & & & & & & & & & & & \\
\hline
\end{tabular}




\subsection{Attachment 4: Paper formal acceptance}

Notification of Formal Acceptance for PONE-D-18-04477R2 [EMID:57adf6bd174b5b92]

PLOS ONE <em@editorialmanager.com>

7 de junho de 2018 16:59

Responder a: PLOS ONE <plosone@plos.org>

Para: Isabele Fattori Moretti <isabelemoretti@gmail.com>

CC: thaisgalatro@usp.br, sknmarie@usp.br, daianegfranco@yahoo.com.br, suelimoba@usp.br

PONE-D-18-04477R2

Plasmatic membrane toll-like receptor expressions in human astrocytomas

Dear Dr. Moretti:

I am pleased to inform you that your manuscript has been deemed suitable for publication in PLOS ONE. Congratulations! Your manuscript is now with our production department.

If your institution or institutions have a press office, please notify them about your upcoming paper at this point, to enable them to help maximize its impact. If they will be preparing press materials for this manuscript, please inform our press team within the next 48 hours. Your manuscript will remain under strict press embargo until 2 pm Eastern Time on the date of publication. For more information please contact onepress@plos.org.

For any other questions or concerns, please email plosone@plos.org.

Thank you for submitting your work to PLOS ONE.

With kind regards,

PLOS ONE Editorial Office Staff on behalf of

Dr. llya Ulasov

Academic Editor

PLOS ONE

8.5. Attachament 5: Published paper in PlosOne - Plasmatic membrane toll-like receptor expressions in human astrocytomas 


\title{
Plasmatic membrane toll-like receptor expressions in human astrocytomas
}

\author{
Isabele Fattori Moretti *, Daiane Gil Franco, Thais Fernanda de Almeida Galatro, Sueli \\ Mieko Oba-Shinjo, Suely Kazue Nagahashi Marie \\ Laboratory of Molecular and Cellular Biology (LIM 15), Department of Neurology, Faculdade de Medicina \\ FMUSP, Universidade de Sao Paulo, Sao Paulo, Brasil \\ * isabelemoretti@usp.br
}

\section{Abstract}

Toll-like receptors (TLRs) are the first to identify disturbances in the immune system, recognizing pathogens such as bacteria, fungi, and viruses. Since the inflammation process plays an important role in several diseases, TLRs have been considered potential therapeutic targets, including treatment for cancer. However, TLRs' role in cancer remains ambiguous. This study aims to analyze the expression levels of plasmatic cell membrane TLRs (TLR1, TLR2, TLR4, TLR5, and TLR6) in human astrocytomas the most prevalent tumors of CNS different grades (II-IV). We demonstrated that TLR expressions were higher in astrocytoma samples compared to non-neoplastic brain tissue. The gene and protein expressions were observed in GBM cell lines U87MG and A172, proving their presence in the tumor cells. Associated expressions between the known heterodimers TLR1-TLR2 were found in all astrocytoma grades. In GBMs, the mesenchymal subtype showed higher levels of TLR expressions in relation to classical and proneural subtypes. A strong association of TLRs with the activation of cell cycle process and signaling through canonical, inflammasome and ripoptosome pathways was observed by in silico analysis, further highlighting TLRs as interesting targets for cancer treatment.

\section{Introduction}

For the past decade, the inflammatory response in the tumor microenvironment has been in the spotlight due to the controversy regarding its ultimate effect. Despite the expectation that inflammation would wield a positive effect against tumorigenesis, relevant studies about the tumor-promoting effects of immune cells have been published. The resulting bioactive molecules from inflammation can provide the tumor microenvironment with growth factors that sustain proliferative signaling, with survival factors that impair apoptosis, along with proangiogenic and extra-cellular matrix-remodeling factors that facilitate invasion, metastasis, and the formation of new blood vessels [1].

Toll-like receptors (TLRs) act as the first line of defense, recognizing nonself-molecules and activating inflammatory processes [2]. Therefore, TLRs have been considered as potential targets for tumor therapeutics $[3,4]$. 
Tecnológico (http://cnpq.br/) grant number 305730/2015-0; Fundação Faculdade de Medicina.

Competing interests: The authors have declared that no competing interests exist.
There are two subgroups of TLRs, based on the subcellular location of these proteins and their respective pathogen-associated molecular pattern (PAMP) ligands. In humans, cell surface TLR1, TLR2, TLR4, TLR5, and TLR6 comprise one group, recognizing mainly microbial membrane components such as lipids, lipoproteins, and proteins. The other group consists of TLR3, TLR7, TLR8, and TLR9, which are expressed exclusively in intracellular vesicles, including endoplasmic reticulum (ER), endosomes, lysosomes, and endolysosomes, and recognizing microbial nucleic acids. TLR2 and TLR4 also identify endogenous molecules rising upon tissue injury, the damage-associated molecular patterns (DAMPs), such as heat-shock proteins, including HSP70, HSP60 Gp96, HSP22, and HSP72, and high-mobility group box-1, protein, as well as extra-cellular matrix (ECM) molecules such as biglycan, tenascin-C, versican, and fragments of ECM molecules (oligosaccharides of hyaluronic acid and heparan sulfate) [5].

Structurally, TLRs are integral membrane receptors, presenting a N-terminal ligand recognition domain, with a leucine-rich repeat motif, a single transmembrane helix, and a C-terminal cytoplasmic signaling domain-known as Toll IL-1 receptor (TIR) domain due to the homology of signaling domains of IL-1R family members [6].

TLR1, TLR2, TLR4, TLR5, and TLR6 are involved in a diversity of cellular responses, ranging from cell proliferation to cell death, and as such they are the targets of the current study in astrocytomas. Cell surface TLRs may present distinct signaling pathways. Below is a brief summary of their signaling pathways:

Canonical signaling pathway of plasmatic membrane TLRs involves myeloid differentiation primary response 88 (MYD88), which activates nuclear factor-kappa B (NF- $\kappa \mathrm{B}$ ) by a protein complex with kinases that recruit tumor necrosis factor receptor associated factor 6 (TRAF6) and leads to proinflammatory cytokines production, such as interleukin-6 (IL-6), interleukin$1 \beta$ (IL-1 $\beta$ ) and $\alpha$, tumor necrosis factor (TNF), interleukin-8 (IL-8) and interleukin-18 (IL18). The final result of this pathway is a cell survival profile [7]. NF- $\kappa \mathrm{B}$ canonical activation after TLR signaling is constituted by the heterodimerization of p65 and p50 subunits. After activation of the I $\mathrm{B}$ kinase, $\mathrm{I} \kappa \mathrm{B}$ is phosphorylated, ubiquitinated, and degraded by the proteasome that enables NF- $\kappa$ B translocation to nucleus, triggering transcriptional activity $[8,9]$. Several of such activated transcripts lead to the upregulation of positive regulators for cell cycle as cyclin D1, with a fundamental role in cellular division and DNA synthesis [10], c-Myc, responsible for enhancing expression of genes related to proliferation [11, 12], c-Jun [13], and serum response factor (SRF) $[14,15]$.

Pathway through TLR2 dimerization with TLR1 or TLR6. TLR2 can form a heterodimer complex with both TLR1 and TLR6 when activated. The heterodimerization of TLR2 with TLR1 or TLR6 expands the ligand spectrum, enabling the innate immune system to recognize different structures of pathogens associated molecular patterns. The downstream signal pathways remain the same for both heterodimers [16].

Pathway through TLR4 endocytosis, activating TIR-domain-containing adapter-inducing interferon- $\beta$ (TRIF), with interferon type 1 response [17].

Pathway through TLR4 activating ripoptosome complex formation, composed of receptorinteracting serine/threonine kinase 1 and 3 (RIPK1/3) and mixed lineage domain kinase like pseudokinase (MLKL), tumor necrosis factor receptor type 1-associated death domain protein (TRADD), and fas-associated protein with death domain (FADD). Ripoptosome activation can lead to apoptosis when caspase 8 (CASP8) is present, or to necroptosis when it is absent. TLR5 and TLR2 are indirectly involved in ripoptosome activation by TNF secretion [18-20].

Pathway through TLR4, TLR2, and TLR5 forming inflammasome complex, with the production of Caspase- 1 and the proinflammatory cytokines IL-1 $\beta$ and IL-18. The inflammasome complex is constituted by NLRP3, PYCARD, and procaspase 1 [21, 22]. 
The present study was performed in astrocytoma, a brain tumor with an astrocytic phenotype. The 2007 World Health Organization (WHO) Classification of Tumors of the Central Nervous System (CNS) divided astrocytomas in four malignant grades, I to IV. Glioblastoma (GBM; grade IV astrocytoma) is the most frequent malignant CNS tumor, with a median overall survival of 15 months under current standard of care treatment, which consists of total macroscopic surgical resection combined with radiotherapy and chemotherapy with the alkylating agent, temozolomide [23, 24].

With the onset of next generation sequencing, it was possible to assess the molecular landscape characterizing GBMs. In an attempt to better elucidate the involved molecular tumorigenic processes, and to better guide the adjuvant therapeutic strategies, three main molecular patterns, associated to somewhat distinct clinical outcomes, were identified: 1) the proneural subtype with molecular markers related to progenitor neuronal cells; 2) the classical subtype with markers of proliferative cells; and 3) the mesenchymal subtype with markers of epithelialmesenchymal transition. Patients exhibiting molecular markers for the mesenchymal subtype presented poor prognosis and the worst response to standard of care, and proneural markers showed better prognosis [25-28]. The result of this initiative prompted a new WHO classification, in 2016, which partially includes molecular aspects of GBMs as segment of its official characterization [29].

This study aims to analyze: 1 ) TLR (1, 2, 4, 5, and 6) expressions in WHO grades II to IV (diffusely infiltrative) human astrocytomas and in GBM molecular subtypes, 2) correlation of TLRs expression levels, and 3) the presence of these receptors in GBM cell lines.

\section{Materials and methods}

\section{Tumor samples and ethical statement}

The studied cases were composed of 140 astrocytoma grade II-IV samples, collected during therapeutic surgical intervention in the Neurology Department of the Hospital das Clinicas of University of Sao Paulo School of Medicine, by the institutional neurosurgery group. The cases were stratified according to the WHO classification as: 22 non-neoplastic (NN) cases from epilepsy surgery, 26 astrocytoma grade II (AGII) cases, 18 astrocytoma grade III (AGIII) cases, and 96 astrocytoma grade IV (GBM) cases, this cohort has been previously published $[30,31]$. The procedures were performed with informed and approved consent according to the Institutional Ethical Committee guidelines at the Hospital das Clinicas of University of Sao Paulo School of Medicine (691/05). The present study was approved by the same institution $(059 / 15)$ to use the biorepository.

\section{Sample preparation and RNA extraction}

The samples were macrodissected and frozen in liquid nitrogen right after the surgical removal, then cryosectioned for RNA extraction. For the tumor tissue analysis, a $6 \mu \mathrm{m}$ thick section and hematoxilin-eosin staining was made to guarantee the absence of necrotic, gliosis, non-neoplastic areas, and more than $80 \%$ of tumor cells in all tumor tissue specimens $[32,33]$.

The RNA extraction was accomplished by the RNeasy Mini Kit (Qiagen, Hilden, Germany) following the manufacturer instructions. The RNA concentration and purity were evaluated by NanoDrop, and 1.8-2.0 values for $260 \mathrm{~nm}$ and $280 \mathrm{~nm}$ absorbance ratios were considered satisfactory. RNA quality was checked by electrophoresis in agarose gel. Reverse transcription was performed with $1 \mu \mathrm{g}$ of RNA treated with DNase I (FPLC-puro, GE Healthcare, Uppsala, Sweden), and amplified with random primers and oligodT oligonucleotides, RNase inhibitor, and the SuperScript III reverse transcriptase (Thermo Fisher Scientific, Carlsbad, CA), following the manufacturer instructions. Finally, the cDNA was treated with RNase H (GE 
Healthcare, Uppsala, Sweden), diluted in TE (Tris/EDTA) buffer and stored at $-20^{\circ} \mathrm{C}$ for posterior use by quantitative real-time PCR (qRT-PCR) analysis.

\section{Quantitative real-time PCR}

TLR1, TLR2, TLR4, TLR5, and TLR6 mRNA levels were evaluated by qRT-PCR, using Power SYBR Green. The results were normalized with the geometrical mean of three reference genes for each sample, as previously described [34]: hypoxanthine phosphoribosyltransferase (HPRT), glucuronidase beta (GUSB), and TATA box-binding protein (TBP). The primers were designed to amplify $80-120 \mathrm{pb}$, with melting temperature around $60^{\circ} \mathrm{C}$ and synthesized by Exxtend (Campinas, Brazil) and IDT (Coralville, IA). The primers were designed as described in Table 1.

Primers were optimized to the minimum concentration for the minor cycle threshold $(\mathrm{Ct})$, the maximum amplification efficiency, and minimum nonspecific amplifications. The mix was composed by cDNA ( $3 \mu \mathrm{l}$ ), Power SYBR Green PCR Master Mix (Thermo Fisher Scientific, Carlsbad, CA) $(6 \mu \mathrm{l})$, and the reverse and forward primers ( $3 \mu \mathrm{l}$ of each). The qRT-PCR was done in duplicate using the ABI Prism 7500 (Thermo Fisher Scientific, Carlsbad, CA) following the protocol: 2 minutes at $50^{\circ} \mathrm{C}, 10$ minutes in $95^{\circ} \mathrm{C}$, and 40 cycles of 15 seconds at $95^{\circ} \mathrm{C}$, and 1 minute at $60^{\circ} \mathrm{C}$. The expression values were assessed by the formula $2^{-\Delta \mathrm{Ct}}$ as $\Delta \mathrm{Ct}$ is: the $\mathrm{Ct}$ of analyzed gene-geometric mean $\mathrm{Ct}$ of the reference genes.

\section{Immunofluorescence}

The presence of TLR proteins in tumor cells was analyzed by immunofluorescence. A172 and U87MG human GBM cell lineages were acquired from ATCC and authenticated by short tandem repeats (STR) analysis using GenePrint 10 System (Promega, Madison, WI). Cells were cultured in monolayer with DMEM medium (Dulbecco's Modified Eagle's Medium, (Thermo Fisher Scientific, Carlsbad, CA), 10\% fetal bovine serum and $100 \mu \mathrm{g} / \mathrm{ml}$ streptomycin and 100 $\mathrm{IU} / \mathrm{ml}$ penicillin.

Cells were fixed with methanol and acetone (1:1), the membrane was permeabilized with Triton-X-100 (0.1\%), and, to avoid unspecific reactions, the cells were treated with $2 \%$ bovine serum albumin. The primary antibodies anti-TLR1 (ab180798, rabbit polyclonal, 1:400 diluted), anti-TLR2 FITC-conjugated (AB_945852, ab59711, mouse monoclonal, 1:50 diluted), anti-TLR4 (AB_446735, ab22048, mouse monoclonal 1:200 diluted), anti-TLR5 (AB_793183, sc-57461, mouse monoclonal, 1:50 diluted, Santa Cruz, CA), and anti-TLR6 (AB_2205406, ab37072, rabbit polyclonal, 1:50 diluted) (Abcam, Cambridge, UK) were incubated overnight at $4^{\circ} \mathrm{C}$. The secondary antibodies (Thermo Fisher Scientific, Carlsbad, CA) goat anti-Rabbit IgG H\&L (Alexa Fluor 568) and goat anti-Mouse IgG H\&L (Alexa Fluor 568 and 488) were

Table 1. Used primer sequences.

\begin{tabular}{l|l|l}
\hline Gene & forward primer (5'-3') & reverse primer (5'-3') \\
\hline$T L R 1$ & GGCACCCCTACAAAAGGAATC & GATAATGGCAAAATGGAAGATGCT \\
\hline$T L R 2$ & TGTGGGTTGAAGCACTGGAC & TTGCGGTCACAAGACAGAGAAG \\
\hline$T L R 4$ & TTTATCCAGGTGTGAAATCCAGAC & TCCAGAAAAGGCTCCCAGG \\
\hline TLR5 & CATACTCCTGATGCTACTGACAACG & GCAGATGAGAGTAGGGAAGTCCA \\
\hline TLR6 & AAACGGCACATTCTTCCACAA & TTTGTCGTTGTTGTTACTGTGGTTG \\
\hline Reference gene & TGAGGATTTGGAAAGGGTGT & AGCACACAGAGGGCTACAA \\
\hline HPRT & GAAAATACGTGGTTGGAGAGCTCATT & CGAGTGAAGATCCCCTTTTTA \\
\hline GUSB & AGGATAAGAGAGCCACGAACCA & CTTGCTGCCAGTCTGGACTGT
\end{tabular}

https://doi.org/10.1371/journal.pone.0199211.t001 
incubated for one hour, and nuclei were stained with DAPI (Thermo Fisher Scientific, Carlsbad, CA). The preparations were analyzed in confocal microscopic Zeiss 510 LSM META and Zeiss 780-NLO (Thornwood, NY). The retrieved images were analyzed by Image J/Fiji [35].

\section{Immunohistochemistry}

Paraffin embedded tissue of five representatives cases of GBM, and five non-neoplastic brain tissue from surgical epilepsy cases were stained for the five TLRs, Iba1, CD68 and GFPA by immunohistochemistry using the Novolink kit (Novolink; Novocastra, Newcastle-upon-Tyne, UK), following the manufacture guide. The sections were processed to antigen retrieval, by citrate buffer $(10 \mathrm{mM}, \mathrm{pH} 6.0)$ for 3 minutes at $122^{\circ} \mathrm{C}$, using an electric cooker (BioCare Medical, Walnut Creek, USA). After protein blocking, the tissue was incubated with antibodies: antiTLR1(ab180798, rabbit polyclonal, 1:800 diluted), anti-TLR2 (AB_307008, ab9100, mouse monoclonal, 1:50 diluted), anti-TLR4 (AB_446735, ab22048, mouse monoclonal 1:800 diluted), anti-TLR5 (AB_793183, sc-57461, mouse monoclonal, 1:500 diluted, Santa Cruz, CA), anti-TLR6 (AB_2205406, ab37072, rabbit polyclonal, 1:200 diluted) (Abcam, Cambridge, UK), anti-CD68 (AB_2687454, M0718, mouse monoclonal, 1:1600 diluted, DAKO, CA), antiIBA1 (AB_2224403, ab15690, mouse monoclonal, 1:700 diluted, Abcam, Cambridge, UK), anti-GFAP (AB_10013382, Z0334, rabbit polyclonal, 1:600, DAKO, CA) at $20^{\circ}$ for 16 hours. The reaction performed by the kit uses diaminobenzidine, and for nuclear staining Harris hematoxylin was used. To obtained optimal dilution tonsil sections was used. The immunoreactions for the five TLRs were analyzed according to a semi-quantitative score system considering the intensity of staining ( 0 : negative, 1 : weak, 2 : moderate and 3 : strong), and percentage of immune-positive cells ( 0 : no cells stained, $0,5: 1-10 \%, 1: 10-25 \%, 2: 26-50 \% 3: 51-75 \%$ and 4: 76-100\%). An immunolabeling score (ILS) was obtained by the product of the intensity of staining and the percentage of stained cells, by two independent investigators (IFM, SKNM), and simultaneous revision were performed to obtain the final score in case the concordance was not achieved. Digital photomicrographs of representative fields were captured and processed using Adobe Illustrator CS6 (Adobe System, San Jose, CA).

\section{Statistical analysis}

The statistical analysis was performed in the program SPSS version 23.0 (IBM, Armonk, NY). The data distribution was evaluated by Kolmogorov-Smirnov test. The non-parametric results were evaluated by Kruskal-Wallis test, followed by post hoc Dunn's test. The correlations between each two receptors gene expression levels were assessed by Spearman-rho. The associations are considered strong when $r \geq 0.7$, moderate when $0.4<r>0.7$, and low when $r \leq 0.4$. Differences were considered significant for $p<0.05$.

The GBM RNAseq dataset from The Cancer Genome Atlas (TCGA - http://cancergenome. nih.gov/) was downloaded from *.rsem.genes.normalized_results address. The data was analyzed by DE-seq and the RPKM values were normalized by the z-score.

\section{Results}

\section{$T L R 1, T L R 2, T L R 4, T L R 5$, and TLR6 mRNAs were up-regulated in diffuse astrocytomas}

Genes coding the five receptors, TLR1, 2, 4, 5, and 6, presented higher expression levels in astrocytoma samples compared to non-neoplastic brain tissues, with statistical significance $(p<0.05)$ (Fig 1A). Only TLR2 expression in AGII did not present any statistical difference compared to NN tissue, in contrast to the statistical difference observed in AGIII and GBM 

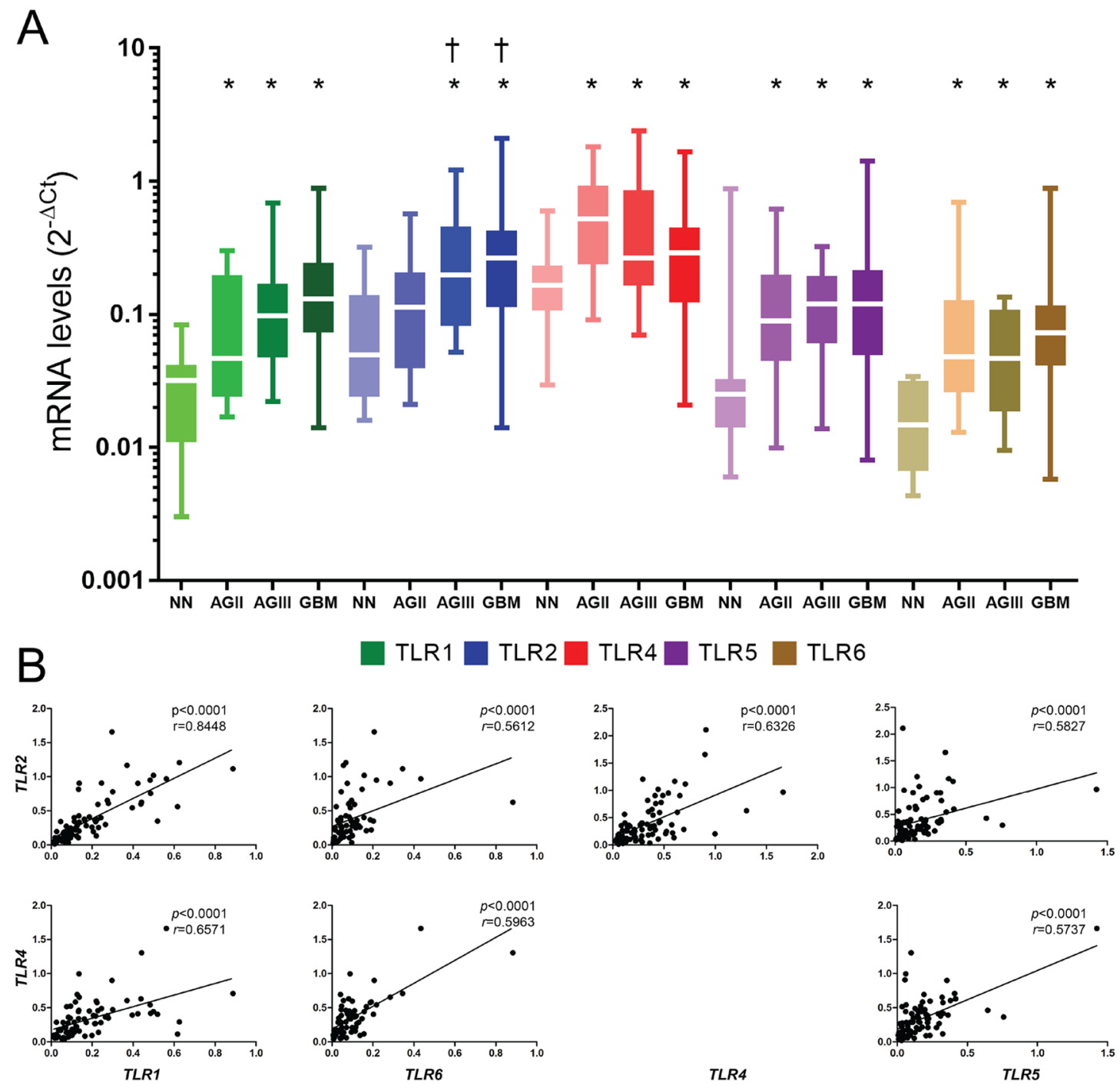

Fig 1. TLR1, TLR2, TLR4, TLR5, and TLR6 expression levels in astrocytomas of different malignant grades. (A) The analyzed samples consisted of 22 non-neoplastic (NN) cases, 26 astrocytoma grade II (AGII) cases, 18 astrocytoma grade III (AGIII) cases, and 96 glioblastoma (GBM) cases. Data are represented by box and whisker plots, with the median represented by the line in the middle of the boxes, and top and bottom boxes represent the first and third quartiles. qRT-PCR values are normalized by three housekeeping genes $(H P R T, G U S B, T B P)$. For statistical analysis, Kruskal-Wallis and Dunn's tests were applied, wherein $\left(^{*}\right) p<0.05$ when compared to NN cases and $(\dagger) p<0.05$ when compared to AGII (Dunn test), all the genes present $p<0.01$ (Kruskal-Wallis). (B) Correlation between TLR2-TLR1, TLR2-TLR6, TLR2-TLR4, TLR2-TLR5, TLR4-TLR1, TLR4-TLR5, and TLR4-TLR6 are demonstrated in GBM cases. Statistical analysis was made by the Spearman-rho correlation, and $p<0.05$ were considered significative.

https://doi.org/10.1371/journal.pone.0199211.g001

$(p<0.05) . T L R 1, T L R 2$, and TLR6 mRNA expression median values showed an increase in parallel to the increase of malignancy. On the other hand, the median TLR4 expression in GBM cases was lower than in the other astrocytoma grades (AGII-AGIII).

\section{Associated TLRs expressions were observed in GBM}

All TLRs expressions were correlated between themselves in GBM, with statistical significance of $p<0.05$ (Fig 1B). Expression levels of TLR2 and TLR1 presented the strongest correlation $(r=0.8448, p<0.0001$ by Spearman-rho test). 


\section{Higher TLR4 and TLR6 median expression levels were observed in mesenchymal GBM compared to other molecular subtypes}

Mesenchymal GBM subtype presented higher TLR4 and TLR6 mRNA median levels than other molecular subtypes in our cohort (S1 Fig.) [36]. However, given the reduced sample number, particularly for the proneural and mesenchymal GBM cases in this cohort, statistical significance was not achieved. Therefore, we performed a similar analysis in molecular GBM subtypes of TCGA public dataset. In this larger cohort, all five TLRs presented higher expression in mesenchymal subtype with statistical significance compared to proneural and classical subtypes (Fig 2).

\section{TLR1, TLR2, TLR4, TLR5, and TLR6 were present in tumor cell lines}

The five TLR proteins were identified in tumor cells, in both GBM cell lineages with mutational status consistent for the mesenchymal subtype (U87MG and A172): RB transcriptional corepressor (RB1) missense mutation in A172, and neurofibromin (NF1) missense and deletion mutation in U87MG [37]. For the immunofluorescence observation (Fig 3), TLR5 presented lower protein expression in U87MG compared to A172. The evaluation of these TLR mRNA levels by qRT-PCR corroborated their presence in both cell lineages; TLR5 mRNA expression level was not detected in U87MG cells by qRT-PCR (S2 Fig.).

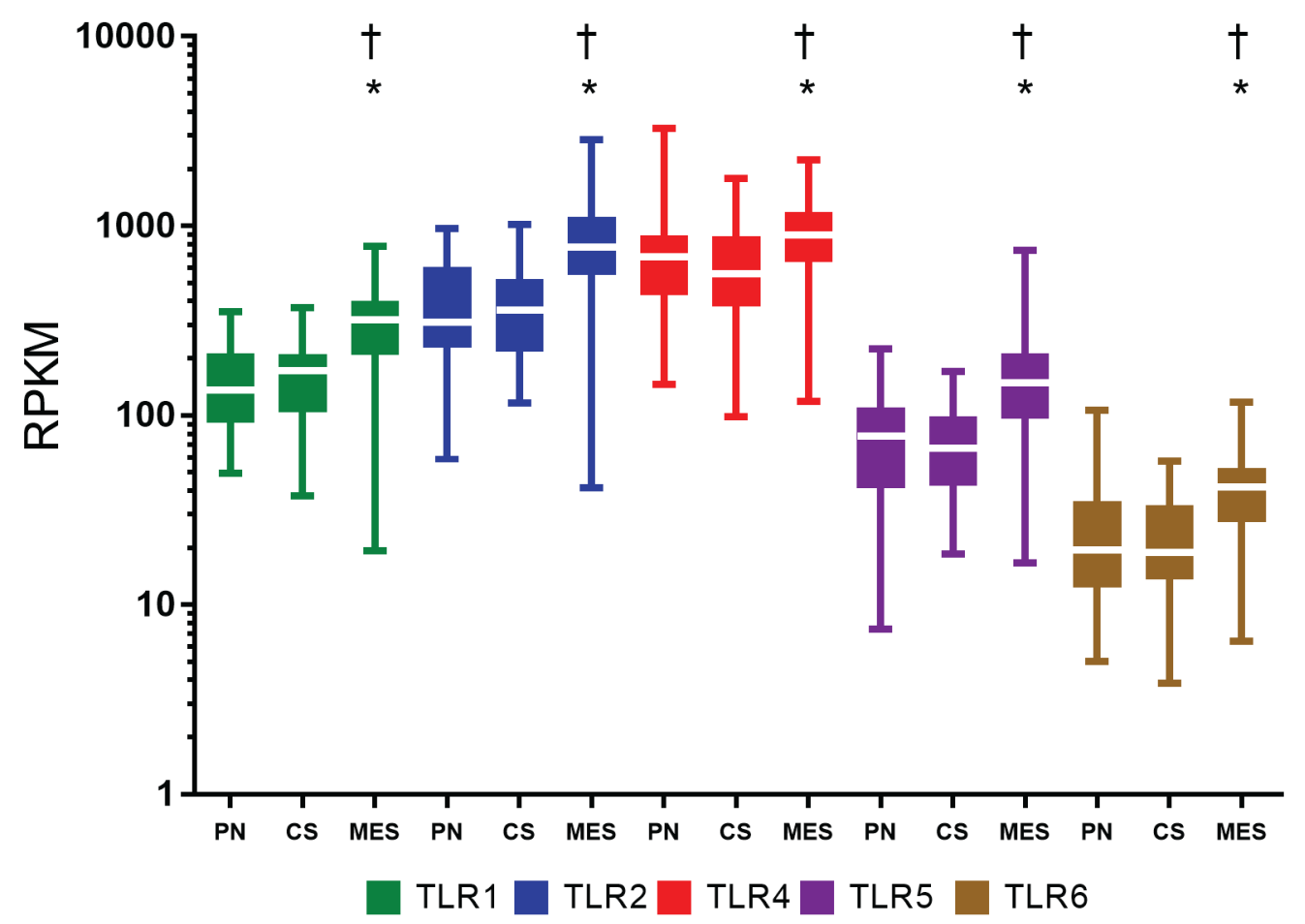

Fig 2. TLR1, TLR2, TLR4, TLR5, and TLR6 expression levels in GBM molecular subtypes from TCGA dataset. Data are represented by box and whisker plots, with the median represented by the line in the middle of the boxes, and top and botton boxes represent the first and third quartiles. The dataset was divided into 37 proneural (PN) cases, 40 classical (CS) subtype cases, and 55 mesenchymal (MES) subtype cases, in which $\left(^{*}\right)$ and $(\dagger)$ are $p<0.05$ when mesenchymal group was compared to proneural cases and to classical cases, respectively (Dunn's test) and $p<0.01$ (Kruskal-Wallis).

https://doi.org/10.1371/journal.pone.0199211.g002 


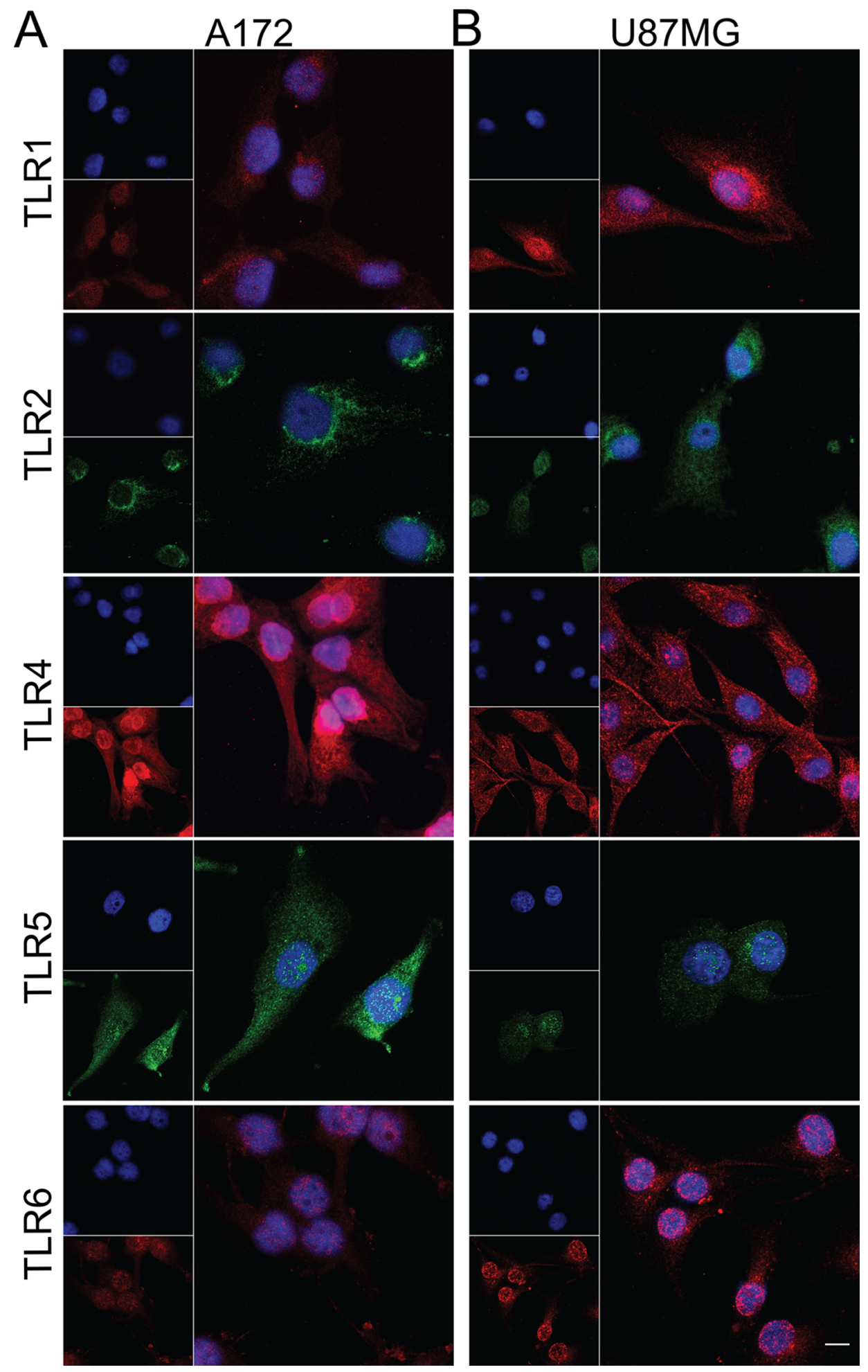

Fig 3. Immunofluorescence of TLR1, TLR2, TLR4, TLR5, and TLR6 in GBM cell lines. A172 (A) and U87MG (B). TLR1, TLR4, and TLR6 are stained in red, TLR2 and TLR5 in green, and nuclei in blue by DAPI. The presence of all five TLRs was detected in both cell lines. Expression of TLR5 was more intense in A172 compared to U87MG. TLR4 and TLR5 positivity were detected in both tumor lineage cells nuclei. Magnification of 400x.

https://doi.org/10.1371/journal.pone.0199211.g003 


\section{$T L R 1, T L R 2, T L R 4, T L R 5$, and TLR6 protein presence in GBM tissue}

The five TLRs proteins were detected in phenotypically GBM cells in all cases, including on the multinucleated GBM cells, corroborating the findings observed in the GBM cell lineages. The TLR4 protein expression was the highest among the five studied TLRs. Interestingly, TLR4 and TLR5 protein expressions were also observed in tumor cell nuclei, as observed in the immunofluorescence preparations of the GBM cell lineages (Fig 4). The presence of few microglia in the GBM tumor sample were detected by IBA1 staining and few macrophages with CD68, which did not overlap with the TLRs positive tumor cells. The positive reaction for GFAP was consistent with the glial origin of the analyzed GBM tumor samples (S3 Fig). Nonneoplastic brain samples were also stained for TLRs. As expected, the positivity for these receptors were observed in neurons and the lowest expression was for TLR2. Similar to the staining pattern in tumor cells, TLR5 positivity was detected in neuron nuclei (S3 Fig).

\section{In silico exploration of TLR signaling pathway}

A heatmap including selected target genes of TLR signaling pathways was built from the TCGA RNAseq dataset. The RPKM values (S4 Fig.) were normalized by the z-score values for
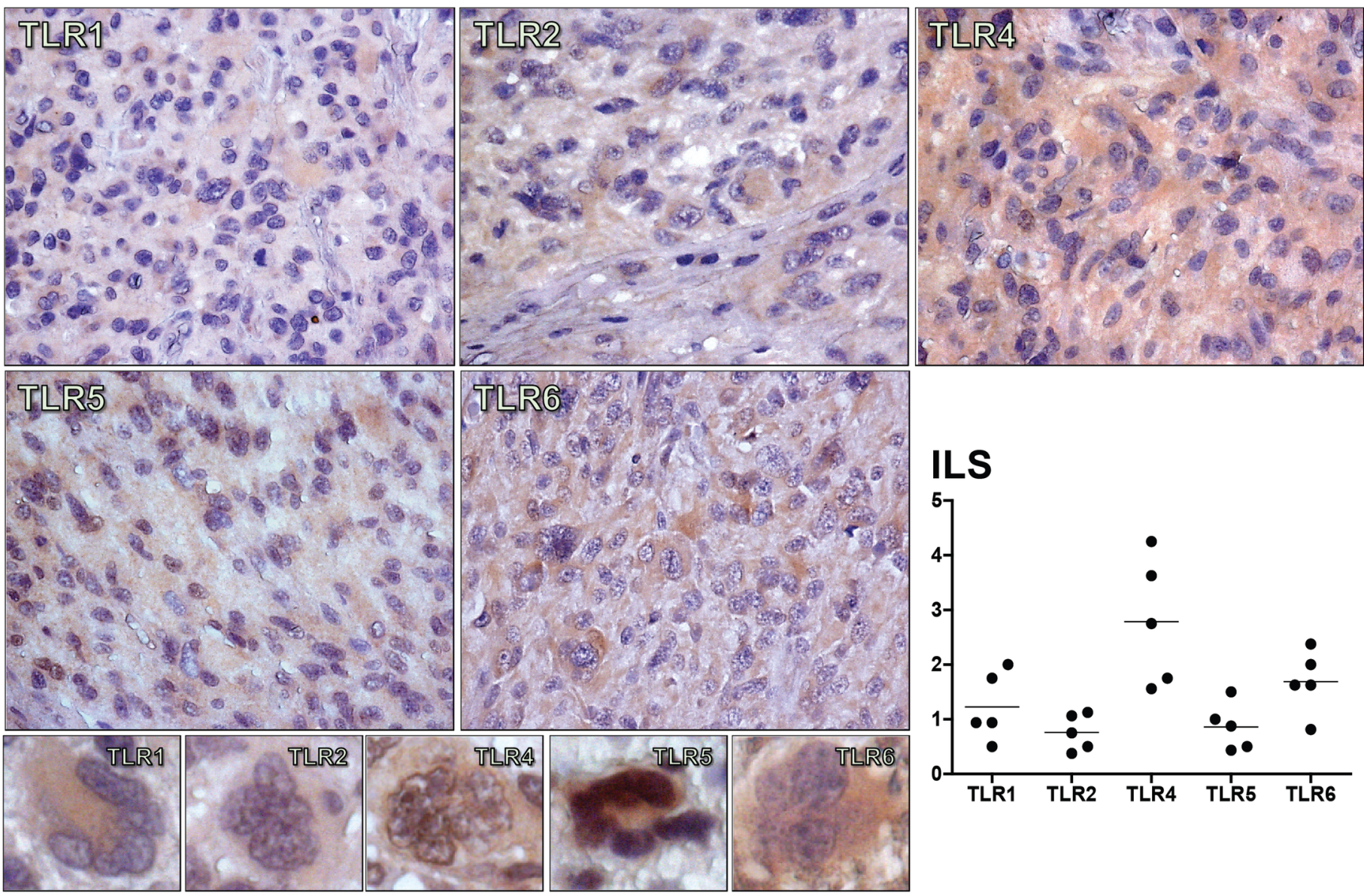

Fig 4. Imunohistochemistry for TLR1, TLR2, TLR4, TLR5, and TLR6 in GBM cases. Positive immunolabelling of GBM tumor cells for TLRs are demonstrated at 600x magnification of tumor tissues, and at 800x magnification in a multinucleated GBM tumor cell. The distribution of the Immunolabeling score (ILS) for these TLRs in five GBM cases was presented as a dispersion graph, where the black dots represent the mean ILS obtained by the two independent investigators for each individual tumor case, and the horizontal bar represent the mean ILS for each receptor. TLR4 and TLR5 positive staining were detected in tumor nuclei.

https://doi.org/10.1371/journal.pone.0199211.g004 
each gene to allow comparative analysis among them (Fig 5). In silico analysis highlighted the higher expression of TLRs in mesenchymal subtype relative to proneural and classical subtypes (S4 Fig.), and pointed out a downstream upregulation through MYD88/TIRAP and NF- $\mathrm{\kappa B}$, ending with increased expression levels of genes that code for cytokines and genes related to cell proliferation. Particularly, expression levels of genes that code for IL-8, IL-6, IL-1 $\alpha$, IL-1 $\beta$, and IL-18 were differentially increased in the mesenchymal GBM subtype compared to the other two subtypes (S4 Fig.). Moreover, RELA, which codes for the nuclear subunit of NF- $\mathrm{\kappa B}$, presented positive correlations $(p<0.05)$ by Spearman-rho test with expression levels of cell proliferation genes: $J U N(r=0.422$ and $r=0.536)$ and $S R F(r=0.462$ and $r=0.577)$ and in mesenchymal and classical subtypes, respectively. In contrast, the gene expressions related to interferon type I response presented low or undetermined z-score values (not shown). Interestingly, expression levels of genes involved in ripoptosome signaling, such as RIPK3 and $M L K L$, were also comparatively increased in mesenchymal GBM subtype, and their values correlated to TLR2 ( $r=0.795$ and $r=0.661$, respectively), and to TLR4 ( $r=0.575$ and $r=0.360$, respectively). Of note, $P Y C A R D, N L R P 3$ and CASP1, which participate in the inflammasome pathway, presented higher expression levels in mesenchymal subtype of GBM compared to the other two subtypes (S4 Fig.).

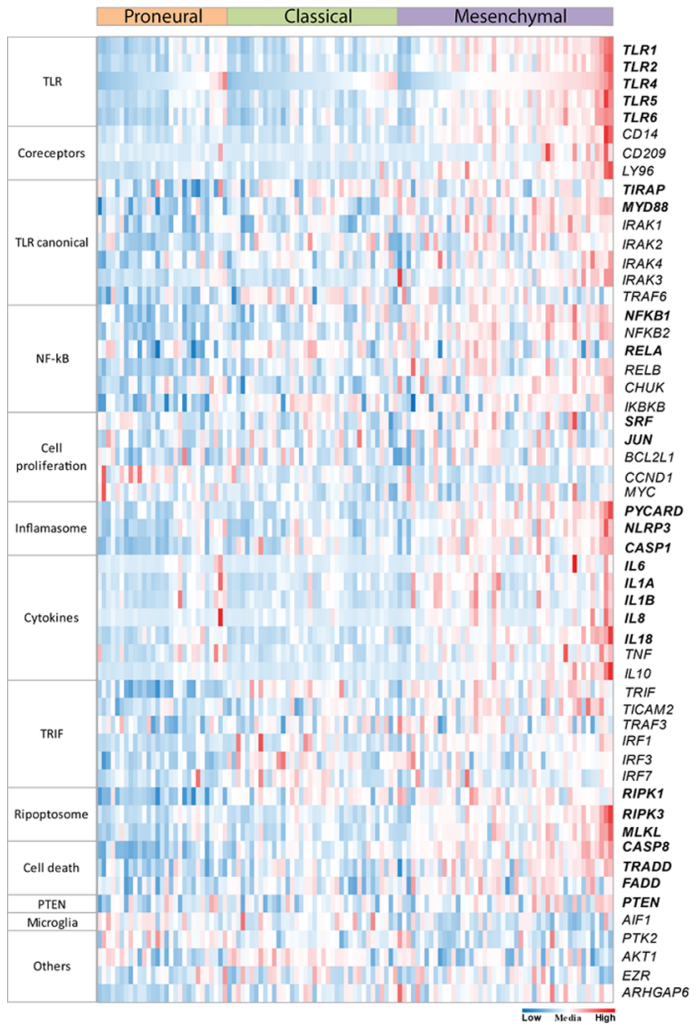

Fig 5. Heatmap with major genes of the TLR signaling pathways from the TCGA dataset. RPKM gene expression levels are normalized by z-scores, and comparatively up-regulated RNA expression values are presented in red and down-regulated values in blue. Mean values are in white. TLRs downstream signaling pathways: canonical, ripoptosome, and inflammasome pathways are activated in mesenchymal GBM subtype. Genes of unrelated pathways were added to show their randomic expression levels, including a microglia marker.

https://doi.org/10.1371/journal.pone.0199211.g005 


\section{Discussion}

In the present study, higher expression levels of TLR1, TLR2, TLR4, TLR5, and TLR6 were demonstrated in human diffusely infiltrating astrocytomas (grades II to IV) in comparison to non-neoplastic brain tissue. Moreover, an associated expression of these receptors were observed in GBM cases, suggesting their role in tumor aggressiveness. The presence of TLR4 has been previously described in GBM, particularly in CD133 $3^{+}$tumor stem cells $[38,39]$, and also in GBM cell lineages A172, U87MG [3, 40,41], and U251 [42]. Such TLR4 positivity conferred a proliferative phenotype to these tumor cells $[38,42]$. Furthermore, the presence of TLR2 was also detected in murine GL261 glioma cell line, and the activation of this receptor leads to an invasive and migratory profile of the tumor cells [43]. We further demonstrated herein the presence of TLR1, TLR2, TLR5, and TLR6 in U87MG and A172 cell lineages and in human GBM specimens, at gene and protein expression levels. TLR4 was the most expressed receptor in both cell lineages and tumor specimens. Interestingly, TLR4 and TLR5 positivity were detected in the tumor cell nuclei by immunofluorescence in cell lineages and by immunohistochemistry in tumor specimens. However, such observation need confirmation in other cohorts before speculating their possible role in this localization (Figs 3, 4 and S2). In spite of both cell lineages presenting somatic mutation profiles of mesenchymal molecular subtype of GBM, they present distinct expression profiles of these TLRs. U87MG cells showed higher expression of TLR1, TLR2, and TLR4 compared to A172, in contrast to lower expression of TLR5 (Figs 3 and S2). Such heterogeneity of these TLRs expression distributions was also observed in human astrocytoma samples from our cohort and in the TCGA dataset, particularly among GBMs, where higher expression levels were detected in mesenchymal subtype (Figs 1, 2, 5 and S1). To analyze the impact of these differential TLRs expressions among the molecular subtypes of GBM, we built a heatmap with the expression levels of the genes involved in pathways related to TLRs from the TCGA dataset (Fig 5). Interestingly, this approach showed clearly the downstream activation of the canonical, ripoptosome, and inflammasome pathways, related to the upregulation of the TLRs, particularly in the mesenchymal subtype of GBM. The end targets of these pathways, including cytokines (IL1A/B, IL6, $I L 8, I L 18)$ and genes related to cell proliferation (JUN, SRF), were upregulated, suggesting that the activation of these TLRs leads to tumor growth. In fact, activation of the TLR canonical pathway through TIRAP-MYD88 was related to NF- $\mathrm{KB}(R E L A)$ upregulated expression levels and positive correlation with $J U N$, and $S R F$, transcription factors implicated in cellular proliferation. The role of NF- $\mathrm{KB}$ in tumor growth has been demonstrated in a mouse model of GBM [44] and in pulmonary tumor cells [45]. Additionally, it has been reported that such a proliferative response may be time- and dose-dependent [46]. Therefore, tumor inflammatory microenvironment may contribute to distinct NF- $\mathrm{\kappa B}$ pulsation-determining tumor cell behavior in each specific condition. The end targets of this pathway, IL-6, IL-1 $\alpha$ and IL-1 $\beta$, and IL- 8 cytokines, presented increased expression in the mesenchymal subtype, and they have also been associated to tumor malignancy and tumor cell migration [22, 47-49]. IL1B and IL18 are also end targets of the inflammasome pathway, which were upregulated in the mesenchymal subtype. On the other hand, the increased expression of RIPK3 and MLKL may suggest the upregulation of the ripoptosome pathway, and may allow the link with the presence of necrosis, one of the characteristics of GBM. In a rat glioma model, apoptosis was induced by activation of CASP8 and inhibition of RIPK1/RIPK3 complex [19, 50, 51].

The expression of CASP 8 was increased in the mesenchymal subtype of GBM; however, increased apoptosis is not expected and, therefore, avoidance of apoptosis should be under additional modulation. Moreover, according to the present in silico analysis, the interferon type I response by TLR4 endocytosis was unlikely. 
Another hypothesis for the proliferative profile and TLR signaling in GBM is the pathway involving PTEN, which has been shown to regulate TIRAP and TLR4 internalization [52, 53], in addition to its classic suppressor role in the PI3K-AKT-mTOR pathway [54]. Loss of function of PTEN may occur by its deletion or phosphorylation [27, 55]. Our previous analysis of PTEN status in our GBM cohort demonstrated $24.32 \%$ and $26.66 \%$ of PTEN deletion, and $59.45 \%$ and $66.66 \%$ of PTEN phosphorylation in classical and mesenchymal subtypes, respectively (S5 Fig.) [36, 55], demonstrating more prevalent PTEN loss of function in the classical subtype. These PTEN alterations may lead to a decreased inhibition over TIRAP (Fig 6) and consequent TLR canonical pathway activation. In B cells, the absence of PTEN showed an increased in NF- $\kappa B$ activity after TLR4 stimulation [56]. Additionally NF- $\kappa B$ negatively regulate PTEN $[57,58]$. Accordingly, in the classical subtype, loss of PTEN may also be implicated in tumor cell proliferation through TLR canonical activation (Fig 5). Actually, our analysis of the TCGA dataset showed significant correlation between TIRAP and PTEN expression levels among the classical GBM subtype $(r=0.330, p<0.05$, Spearman-rho test). Interestingly, a negative correlation was found between them in the proneural subtype $(r=-0.382, p<0.05)$, which presents better prognosis among the three analyzed GBM subtypes.
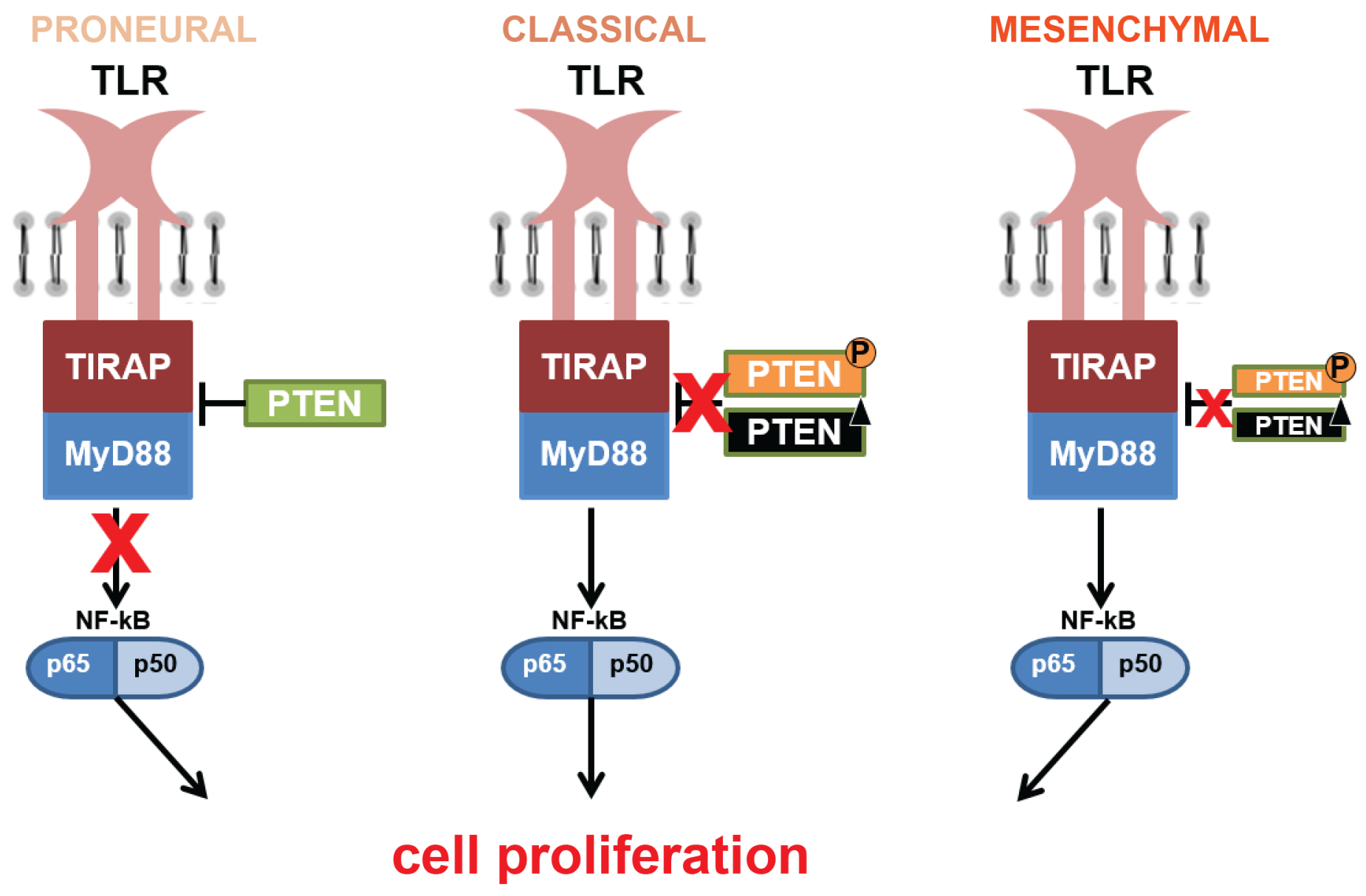

Fig 6. Schematic proposition of the TLR canonical signaling pathway through TIRAP by PTEN regulation. PTEN alterations may lead to upregulation of TLR signaling pathway and may increase tumor cell proliferation. Loss of PTEN repressor role by its deletion or phosphorylation, as may occur more frequently in classical subtype, may activate downstream TLR canonical pathway through the decreased inhibition over TIRAP. This pathway through TIRAP-PTEN may not be the major mechanism in mesenchymal subtype, and the integrity of PTEN may inhibit TIRAP and then not activate this pathway in proneural subtype. 
In summary, increased cell membrane TLR1, TLR2, TLR4, TLR5, and TLR6 expressions were demonstrated in astrocytomas compared to non-neoplastic brain tissue, mostly in GBM group, and particularly in the mesenchymal subtype. In silico exploration of the putative activation pathways by these upregulated TLRs, the canonical and inflammasome pathways in the mesenchymal subtype and the PTEN-TIRAP signaling in the classical subtype demonstrated their increase and their possible contribution to tumor growth. According to the TCGA dataset the microglia compartment based on AIF1 expression level did not parallel the TLRs upregulated expressions in mesenchymal subtype, suggesting that the tumor cells themselves may contribute to the increased expression of these receptors.

Further understanding of the particular TLR responses from each tumor compartment, which includes inflammatory cells in addition to tumor cells, will be essential to designing new therapeutic strategies involving TLRs.

\section{Supporting information}

S1 Fig. TLRs expression levels in the GBM subtypes of our cohort composed of 14 proneural (PN), 38 classical (CS) and 16 mesenchymal (MES) subtype cases. Horizontal bars indicate the mean value of each group.

S2 Fig. TLRs expression levels in U87MG and A172 cell lines. A heterogeneity in the distribution of the five TLRs is observed between the cell lines, although both GBM cell lines present somatic mutation profiles of mesenchymal subtype. TLR 4 expression is high in both cell lines, whereas TLR5 is undetectable in U87MG cell line.

(TIF)

S3 Fig. TLRs protein expression in non-neoplastic cases and microglia and macrophage detection in GBM sample. Immunohistochemistry for a representative non-neoplastic case stained for TLR1, TLR2, TLR4, TLR5, TLR6 and GFAP for glial cell identification. Presence of few microglia in the same GBM sample of Fig 4 was observed by IBA1 staining, and also few macrophages was detected by CD68 staining. GFAP positivity was shown in the GBM tumor sample confirming the glial origin of the tumor.

S4 Fig. Expression levels of the genes participating in the TLR signaling pathways divided by GBM molecular subtypes: Proneural, classical, and mesenchymal from the TCGA RNASeq dataset. The dataset is composed of 37 proneural (PN), 40 classical (CS), and 55 mesenchymal (MES) subtype cases, wherein $\left({ }^{*}\right) p<0.05$ when compared to proneural cases and $(\dagger)$ $p<0.05$ when compared to classical cases by Kruskal-Wallis and Dunn's test. The values were normalized in DEseq.

S5 Fig. PTEN. The GBM cohort from our lab was previously analyzed for PTEN mutational and phosphorylation status. The number of cases for each status of PTEN and GBM subtype are presented. In green is the amount of cases presenting wild-type PTEN, in black the deleted PTEN, and in orange the Y240-phosphorylated PTEN.

\section{Acknowledgments}

We thank the doctors and residents from the Discipline of Neurosurgery of the Department of Neurology at Hospital das Clinicas of School of Medicine, University of São Paulo, for patients' 
therapeutic and diagnostic procedures included in this study. We also thank the physicians and technicians at the Division of Pathological Anatomy of the same institutions, particularly Dr. Sergio Rosemberg for assistance with the histological classifications of tumor samples.

\section{Author Contributions}

Conceptualization: Suely Kazue Nagahashi Marie.

Formal analysis: Isabele Fattori Moretti, Suely Kazue Nagahashi Marie.

Funding acquisition: Suely Kazue Nagahashi Marie.

Investigation: Isabele Fattori Moretti, Suely Kazue Nagahashi Marie.

Methodology: Isabele Fattori Moretti, Daiane Gil Franco.

Supervision: Suely Kazue Nagahashi Marie.

Validation: Isabele Fattori Moretti.

Writing - original draft: Isabele Fattori Moretti, Suely Kazue Nagahashi Marie.

Writing - review \& editing: Isabele Fattori Moretti, Thais Fernanda de Almeida Galatro, Sueli Mieko Oba-Shinjo, Suely Kazue Nagahashi Marie.

\section{References}

1. Hanahan D, Weinberg Robert A. Hallmarks of Cancer: The Next Generation. Cell. 2011; 144(5):64674. https://doi.org/10.1016/j.cell.2011.02.013 PMID: 21376230

2. Kawai T, Akira S. The role of pattern-recognition receptors in innate immunity: update on Toll-like receptors. Nature Immunology. 2010; 11(5):373-84. https://doi.org/10.1038/ni.1863 PMID: 20404851

3. Rakoff-Nahoum S, Medzhitov R. Toll-like receptors and cancer. Nat Rev Cancer. 2009; 9(1):57-63. https://doi.org/10.1038/nrc2541 PMID: 19052556

4. Pradere JP, Dapito DH, Schwabe RF. The Yin and Yang of Toll-like receptors in cancer. Oncogene. 2014; 33(27):3485-95. https://doi.org/10.1038/onc.2013.302 PMID: 23934186

5. Piccinini AM, Midwood KS. DAMPening Inflammation by Modulating TLR Signalling. Mediators of Inflammation. 2010; 2010:672395. https://doi.org/10.1155/2010/672395 PMID: 20706656

6. Botos I, Segal DM, Davies DR. The Structural Biology of Toll-like Receptors. Structure. 2011; 19 (4):447-59. https://doi.org/10.1016/j.str.2011.02.004 PMID: 21481769

7. Ben-Neriah $\mathrm{Y}$, Karin M. Inflammation meets cancer, with NF-[kappa]B as the matchmaker. Nat Immunol. 2011; 12(8):715-23. https://doi.org/10.1038/ni.2060 PMID: 21772280

8. Hayden MS, Ghosh S. Signaling to NF-kappaB. Genes Dev. 2004; 18(18):2195-224. https://doi.org/10. 1101/gad.1228704 PMID: 15371334

9. Karin M, Ben-Neriah Y. Phosphorylation meets ubiquitination: the control of NF-[kappa]B activity. Annu Rev Immunol. 2000; 18:621-63. https://doi.org/10.1146/annurev.immunol.18.1.621 PMID: 10837071

10. Qin Z-h, Tao L-y, Chen X. Dual roles of NF-[kappa]B in cell survival and implications of NF-[kappa]B inhibitors in neuroprotective therapy. Acta Pharmacol Sin. 2007; 28(12):1859-72. https://doi.org/10. 1111/j.1745-7254.2007.00741.x PMID: 18031598

11. David A, Arnaud N, Fradet M, Lascaux H, Ouk-Martin C, Gachard N, et al. C-Myc dysregulation is a cotransforming event for nuclear factor-kappaB activated B cells. Haematologica. 2017; 102(5):883-94. https://doi.org/10.3324/haematol.2016.156281 PMID: 28232371

12. Lin CY, Lovén J, Rahl PB, Paranal RM, Burge CB, Bradner JE, et al. Transcriptional Amplification in Tumor Cells with Elevated c-Myc. Cell. 2012; 151(1):56-67. https://doi.org/10.1016/j.cell.2012.08.026 PMID: 23021215

13. Mechta-Grigoriou F, Gerald D, Yaniv M. The mammalian Jun proteins: redundancy and specificity. Oncogene. 2001; 20(19):2378-89. https://doi.org/10.1038/sj.onc.1204381 PMID: 11402334

14. Schratt G, Weinhold B, Lundberg AS, Schuck S, Berger J, Schwarz H, et al. Serum response factor is required for immediate-early gene activation yet is dispensable for proliferation of embryonic stem cells. Mol Cell Biol. 2001; 21(8):2933-43. https://doi.org/10.1128/MCB.21.8.2933-2943.2001 PMID: 11283270 
15. Chaturvedi MM, Sung B, Yadav VR, Kannappan R, Aggarwal BB. NF-kappaB addiction and its role in cancer: 'one size does not fit all'. Oncogene. 2011; 30(14):1615-30. https://doi.org/10.1038/onc.2010. 566 PMID: 21170083

16. Farhat K, Riekenberg S, Heine H, Debarry J, Lang R, Mages J, et al. Heterodimerization of TLR2 with TLR1 or TLR6 expands the ligand spectrum but does not lead to differential signaling. Journal of Leukocyte Biology. 2008; 83(3):692-701. https://doi.org/10.1189/jlb.0807586 PMID: 18056480

17. Tan $Y$, Zanoni I, Cullen Thomas W, Goodman Andrew L, Kagan Jonathan C. Mechanisms of Toll-like Receptor 4 Endocytosis Reveal a Common Immune-Evasion Strategy Used by Pathogenic and Commensal Bacteria. Immunity. 2015; 43(5):909-22. https://doi.org/10.1016/j.immuni.2015.10.008 PMID: 26546281

18. Kaiser WJ, Sridharan H, Huang C, Mandal P, Upton JW, Gough PJ, et al. Toll-like Receptor 3-mediated Necrosis via TRIF, RIP3, and MLKL. The Journal of Biological Chemistry. 2013; 288(43):31268-79. https://doi.org/10.1074/jbc.M113.462341 PMID: 24019532

19. Newton K, Dugger DL, Maltzman A, Greve JM, Hedehus M, Martin-McNulty B, et al. RIPK3 deficiency or catalytically inactive RIPK1 provides greater benefit than MLKL deficiency in mouse models of inflammation and tissue injury. Cell Death Differ. 2016; 23(9):1565-76. https://doi.org/10.1038/cdd.2016.46 PMID: 27177019

20. Najjar M, Saleh D, Zelic M, Nogusa S, Shah S, Tai A, et al. RIPK1 and RIPK3 Kinases Promote CellDeath-Independent Inflammation by Toll-like Receptor 4. Immunity. 45(1):46-59. https://doi.org/10. 1016/j.immuni.2016.06.007 PMID: 27396959

21. Guo H, Callaway JB, Ting JPY. Inflammasomes: mechanism of action, role in disease, and therapeutics. Nat Med. 2015; 21(7):677-87. https://doi.org/10.1038/nm.3893 PMID: 26121197

22. Guo B, Fu S, Zhang J, Liu B, Li Z. Targeting inflammasome/IL-1 pathways for cancer immunotherapy. Sci Rep. 2016; 6:36107. https://doi.org/10.1038/srep36107 PMID: 27786298

23. Louis DN, Ohgaki H, Wiestler OD, Cavenee WK, Burger PC, Jouvet A, et al. The 2007 WHO classification of tumours of the central nervous system (vol 114, pg 97, 2007). Acta Neuropathologica. 2007; 114 (5):547-. https://doi.org/10.1007/s00401-007-0243-4 PMID: 17618441

24. Stupp R, Mason WP, van den Beuf MJ. Radiotherapy plus concomitant and adjuvant temozolomide for newly diagnosed glioblastoma (vol 352, pg 19, 2005). Annals of Oncology. 2005; 16(6):949-. https:// doi.org/10.1056/NEJMoa043330 PMID: 15758009

25. Phillips HS, Kharbanda S, Chen R, Forrest WF, Soriano RH, Wu TD, et al. Molecular subclasses of high-grade glioma predict prognosis, delineate a pattern of disease progression, and resemble stages in neurogenesis. Cancer Cell. 2006; 9(3):157-73. https://doi.org/10.1016/j.ccr.2006.02.019 PMID: 16530701

26. Colman H, Zhang L, Sulman EP, McDonald JM, Shooshtari NL, Rivera A, et al. A multigene predictor of outcome in glioblastoma. Neuro Oncol. 2010; 12(1):49-57. https://doi.org/10.1093/neuonc/nop007 PMID: 20150367

27. Verhaak RG, Hoadley KA, Purdom E, Wang V, Qi Y, Wilkerson MD, et al. Integrated genomic analysis identifies clinically relevant subtypes of glioblastoma characterized by abnormalities in PDGFRA, IDH1, EGFR, and NF1. Cancer Cell. 2010; 17(1):98-110. https://doi.org/10.1016/j.ccr.2009.12.020 PMID: 20129251

28. Wang Q, Hu B, Hu X, Kim H, Squatrito M, Scarpace L, et al. Tumor Evolution of Glioma-Intrinsic Gene Expression Subtypes Associates with Immunological Changes in the Microenvironment. Cancer Cell. 32(1):42-56.e6. https://doi.org/10.1016/j.ccell.2017.06.003 PMID: 28697342

29. Louis DN, Perry A, Reifenberger G, von Deimling A, Figarella-Branger D, Cavenee WK, et al. The 2016 World Health Organization Classification of Tumors of the Central Nervous System: a summary. Acta Neuropathol. 2016; 131(6):803-20. https://doi.org/10.1007/s00401-016-1545-1 PMID: 27157931

30. Galatro TFdA, Uno M, Oba-Shinjo SM, Almeida AN, Teixeira MJ, Rosemberg S, et al. Differential Expression of ID4 and Its Association with TP53 Mutation, SOX2, SOX4 and OCT-4 Expression Levels. PLOS ONE. 2013; 8(4):e61605. https://doi.org/10.1371/journal.pone.0061605 PMID: 23613880

31. da Silva R, Uno M, Marie SKN, Oba-Shinjo SM. LOX Expression and Functional Analysis in Astrocytomas and Impact of IDH1 Mutation. PLOS ONE. 2015; 10(3):e0119781. https://doi.org/10.1371/journal. pone.0119781 PMID: 25790191

32. Marie SKN, Okamoto OK, Uno M, Hasegawa APG, Oba-Shinjo SM, Cohen T, et al. Maternal embryonic leucine zipper kinase transcript abundance correlates with malignancy grade in human astrocytomas. International Journal of Cancer. 2008; 122(4):807-15. https://doi.org/10.1002/ijc.23189 PMID: 17960622

33. Oba-Shinjo SM, Bengtson MH, Winnischofer SMB, Colin C, Vedoy CG, de Mendonca Z, et al. Identification of novel differentially expressed genes in human astrocytomas by cDNA representational 
difference analysis. Molecular Brain Research. 2005; 140(1-2):25-33. https://doi.org/10.1016/j. molbrainres.2005.06.015 PMID: 16084624

34. Valente V, Teixeira SA, Neder L, Okamoto OK, Oba-Shinjo SM, Marie SKN, et al. Selection of suitable housekeeping genes for expression analysis in glioblastoma using quantitative RT-PCR. Bmc Molecular Biology. 2009; 10:11. https://doi.org/10.1186/1471-2199-10-11

35. Schindelin J, Arganda-Carreras I, Frise E, Kaynig V, Longair M, Pietzsch T, et al. Fiji: an open-source platform for biological-image analysis. Nat Methods. 2012; 9(7):676-82. https://doi.org/10.1038/nmeth. 2019 PMID: 22743772

36. Galatro TF, Sola P, Moretti IF, Miura FK, Oba-Shinjo S, Marie SK, et al. Correlation between molecular features and genetic subtypes of Glioblastoma: critical analysis in 109 cases. MedicalExpress. 2017 (Oct):M170505.

37. Forbes SA, Beare D, Gunasekaran P, Leung K, Bindal N, Boutselakis H, et al. COSMIC: exploring the world's knowledge of somatic mutations in human cancer. Nucleic Acids Research. 2015; 43(D1): D805-D11. https://doi.org/10.1093/nar/gku1075 PMID: 25355519

38. Che F, Yin J, Quan Y, Xie X, Heng X, Du Y, et al. TLR4 interaction with LPS in glioma CD133+ cancer stem cells induces cell proliferation, resistance to chemotherapy and evasion from cytotoxic T lymphocyte-induced cytolysis. Oncotarget. 2017; 8(32):53495-507. https://doi.org/10.18632/oncotarget.18586 PMID: 28881826

39. Brescia $P$, Ortensi B, Fornasari L, Levi D, Broggi G, Pelicci G. CD133 is essential for glioblastoma stem cell maintenance. Stem Cells. 2013; 31(5):857-69. https://doi.org/10.1002/stem.1317 PMID: 23307586

40. Gupta P, Ghosh S, Nagarajan A, Mehta VS, Sen E. ß-defensin-3 negatively regulates TLR4-HMGB1 axis mediated HLA-G expression in IL-1 $\beta$ treated glioma cells. Cellular Signalling. 2013; 25(3):682-9. https://doi.org/10.1016/j.cellsig.2012.12.001 PMID: 23220408

41. Sarrazy V, Vedrenne N, Billet F, Bordeau N, Lepreux S, Vital A, et al. TLR4 signal transduction pathways neutralize the effect of Fas signals on glioblastoma cell proliferation and migration. Cancer Lett. 2011; 311(2):195-202. https://doi.org/10.1016/j.canlet.2011.07.018 PMID: 21852034

42. Thuringer D, Hammann A, Benikhlef N, Fourmaux E, Bouchot A, Wettstein G, et al. Transactivation of the epidermal growth factor receptor by heat shock protein 90 via Toll-like receptor 4 contributes to the migration of glioblastoma cells. J Biol Chem. 2011; 286(5):3418-28. https://doi.org/10.1074/jbc.M110. 154823 PMID: 21127066

43. Wang $F$, Zhang $P$, Yang L, Yu X, Ye X, Yang J, et al. Activation of toll-like receptor 2 promotes invasion by upregulating MMPs in glioma stem cells. American Journal of Translational Research. 2015; 7 (3):607-15.PMID: 26045899

44. Friedmann-Morvinski D, Narasimamurthy $R$, Xia $Y$, Myskiw $C$, Soda $Y$, Verma IM. Targeting NF-kB in glioblastoma: A therapeutic approach. Sci Adv. 22016. https://doi.org/10.1126/sciadv.1501292 PMID: 26824076

45. Bivona TG, Hieronymus $\mathrm{H}$, Parker J, Chang $\mathrm{K}$, Taron M, Rosell R, et al. FAS and NF-kappaB signalling modulate dependence of lung cancers on mutant EGFR. Nature. 2011; 471(7339):523-6. https://doi. org/10.1038/nature09870 PMID: 21430781

46. Turner DA, Paszek P, Woodcock DJ, Nelson DE, Horton CA, Wang Y, et al. Physiological levels of TNFalpha stimulation induce stochastic dynamics of NF-kappaB responses in single living cells. J Cell Sci. 2010;123(Pt 16):2834-43. https://doi.org/10.1242/jcs.069641 PMID: 20663918

47. Fisher DT, Appenheimer MM, Evans SS. The two faces of IL-6 in the tumor microenvironment. Semin Immunol. 2014; 26(1):38-47. https://doi.org/10.1016/j.smim.2014.01.008 PMID: 24602448

48. Ahn S-H, Park H, Ahn Y-H, Kim S, Cho M-S, Kang JL, et al. Necrotic cells influence migration and invasion of glioblastoma via NF-KB/AP-1-mediated IL-8 regulation. Scientific Reports. 2016; 6:24552. https://doi.org/10.1038/srep24552 PMID: 27076368

49. Lewis $\mathrm{AM}$, Varghese $\mathrm{S}, \mathrm{Xu} \mathrm{H}$, Alexander HR. Interleukin-1 and cancer progression: the emerging role of interleukin-1 receptor antagonist as a novel therapeutic agent in cancer treatment. Journal of Translational Medicine. 2006; 4:48-. https://doi.org/10.1186/1479-5876-4-48 PMID: 17096856

50. Raza SM, Lang FF, Aggarwal BB, Fuller GN, Wildrick DM, Sawaya R. Necrosis and glioblastoma: a friend or a foe? A review and a hypothesis. Neurosurgery. 2002; 51(1):2-12; discussion -3.PMID: 12182418

51. Das A, McDonald DG, Dixon-Mah YN, Jacqmin DJ, Samant VN, Vandergrift WA, et al. RIP1 and RIP3 complex regulates radiation-induced programmed necrosis in glioblastoma. Tumor Biology. 2016; 37 (6):7525-34. https://doi.org/10.1007/s13277-015-4621-6 PMID: 26684801

52. Aksoy E, Taboubi S, Torres D, Delbauve S, Hachani A, Whitehead MA, et al. The p110[delta] isoform of the kinase $\mathrm{PI}(3) \mathrm{K}$ controls the subcellular compartmentalization of TLR4 signaling and protects from 
endotoxic shock. Nat Immunol. 2012; 13(11):1045-54. https://doi.org/10.1038/ni.2426 PMID: 23023391

53. Yin $\mathrm{H}$, Tan $\mathrm{Y}$, Wu X, Yan H, Liu F, Yao Y, et al. Association between TLR4 and PTEN Involved in LPSTLR4 Signaling Response. Biomed Res Int. 2016; 2016:6083178. https://doi.org/10.1155/2016/ 6083178 PMID: 27563672

54. Song MS, Salmena L, Pandolfi PP. The functions and regulation of the PTEN tumour suppressor. Nat Rev Mol Cell Biol. 2012; 13(5):283-96. https://doi.org/10.1038/nrm3330 PMID: 22473468

55. Fenton TR, Nathanson D, Ponte de Albuquerque C, Kuga D, Iwanami A, Dang J, et al. Resistance to EGF receptor inhibitors in glioblastoma mediated by phosphorylation of the PTEN tumor suppressor at tyrosine 240. Proc Natl Acad Sci U S A. 2012; 109(35):14164-9. https://doi.org/10.1073/pnas. 1211962109 PMID: 22891331

56. Singh AR, Peirce SK, Joshi S, Durden DL. PTEN and PI-3 kinase inhibitors control LPS signaling and the lymphoproliferative response in the CD19+ B cell compartment. Exp Cell Res. 2014; 327(1):78-90. https://doi.org/10.1016/j.yexcr.2014.05.016 PMID: 24881819

57. Hai Ping P, Feng Bo T, Li L, Nan Hui Y, Hong Z. IL-1beta/NF-kb signaling promotes colorectal cancer cell growth through miR-181a/PTEN axis. Arch Biochem Biophys. 2016; 604:20-6. https://doi.org/10. 1016/j.abb.2016.06.001 PMID: 27264420

58. Oliva-Gonzalez C, Uresti-Rivera EE, Galicia-Cruz OG, Jasso-Robles FI, Gandolfi AJ, EscuderoLourdes $C$. The tumor suppressor phosphatase and tensin homolog protein (PTEN) is negatively regulated by NF-kappab p50 homodimers and involves histone 3 methylation/deacetylation in UROtsa cells chronically exposed to monomethylarsonous acid. Toxicol Lett. 2017; 280:92-8. https://doi.org/10. 1016/j.toxlet.2017.08.013 PMID: 28823542 